\title{
Chronic Hepatitis B
}

\author{
Anna S. F. Lok ${ }^{1}$ and Brian J. McMahon ${ }^{2}$
}

This guideline has been approved by the American Association for the Study of Liver Diseases and represents the position of the Association.

\section{Preamble}

These guidelines have been written to assist physicians and other health care providers in the recognition, diagnosis, and management of patients chronically infected with the hepatitis B virus (HBV). These recommendations provide a data-supported approach to patients with hepatitis B. They are based on the following: (1) formal review and analysis of published literature on the topic Medline search up to February 2006 and meeting abstracts in 2003-2005; (2) American College of Physicians Manual for Assessing Health Practices and Designing Practice Guidelines ${ }^{1}$; (3) guideline policies, including the AASLD Policy on the Development and Use of Practice Guidelines and the AGA Policy Statement on Guidelines ${ }^{2}$; and (4) the experience of the authors in hepatitis B. In addition, the proceedings of the 2000 and $2006 \mathrm{Na}$ tional Institutes of Health conferences on the "Management of Hepatitis B", the EASL 2002 International Consensus Conference on Hepatitis B and the Asian-Pacific Consensus Statement on the Management of Chronic Hepatitis B: a 2005 Update, were considered in the development of these guidelines. ${ }^{3-6}$ The recommen-

Abbreviations: $H B V$, hepatitis $B$ virus; $H B s A g$, hepatitis $B$ surface antigen, $H C C$, hepatocellular carcinoma; $H B e A g$, hepatitis $B$ e antigen; cccDNA, covalently closed circular DNA; anti-HBe, antibody to hepatitis $B$ e antigen; $A L T$, alanine aminotransferase; anti-HBs, antibody to hepatitis $B$ surface antigen; $P C R$, polymerase chain reaction; $H C V$, hepatitis $C$ virus; $H I V$, human immunodeficiency virus; $H D V$, hepatitis D virus; $H B I G$, hepatitis B immunoglobulin; AFP, alpha fetoprotein; US, ultrasonography; IFN- $\alpha$, interferon-alfa; pegIFN- $\alpha$, pegylated interferonalfa.

From the ${ }^{1}$ Division of Gastroenterology, University of Michigan Medical Center, Ann Arbor, MI; and the ${ }^{2}$ Liver Disease and Hepatitis Program, Alaska Native Medical Center and Arctic Investigations Program, Centers for Disease Control, Anchorage, AK.

Address reprint requests to: Anna S. F. Lok, M.D., Division of Gastroenterology, University of Michigan Medical Center, 3912 Taubman Center, Box 0362, Ann Arbor, MI 48109-0362. E-mail: aslok@umich.edu; fax: 734-936-7392.

Copyright (C) 2007 by the American Association for the Study of Liver Diseases.

Published online in Wiley InterScience (www.interscience.wiley.com). DOI 10.1002/hep.21513

Potential conflict of interest: Dr. McMahon's spouse owns stock in GlaxoSmithKline. Dr. Lok is a consultant for, received grants, and is on the Scientific Advisory Board of, Bristol-Myers Squibb, GlaxoSmithKline, Idenix, Roche, Gilead, and Innogenetics. She is also on the Scientific Advisory Board of Pharmasset. Dr. Lok received grants from Schering-Plough.

Please refer to www. aasld.org for disclosures by Practice Guidelines Committee members. dations suggest preferred approaches to the diagnostic, therapeutic, and preventive aspects of care. They are intended to be flexible. Specific recommendations are based on relevant published information. In an attempt to characterize the quality of evidence supporting recommendations, the Practice Guidelines Committee of the AASLD requires a category to be assigned and reported with each recommendation (Table 1 ). These guidelines may be updated periodically as new information becomes available.

\section{Introduction}

An estimated 350 million persons worldwide are chronically infected with HBV. ${ }^{7}$ In the United States, there are an estimated 1.25 million hepatitis B carriers, defined as persons positive for hepatitis $B$ surface antigen (HBsAg) for more than 6 months. ${ }^{8,9}$ Carriers of HBV are at increased risk of developing cirrhosis, hepatic decompensation, and hepatocellular carcinoma (HCC). ${ }^{10} \mathrm{Al}-$ though most carriers will not develop hepatic complications from chronic hepatitis B, $15 \%$ to $40 \%$ will develop serious sequelae during their lifetime. ${ }^{11}$ The following guidelines are an update to previous AASLD guidelines and reflect new knowledge and the licensure of new antiviral agents against HBV. Recommendations in these guidelines pertain to the (1) evaluation of patients with chronic HBV infection, (2) prevention of HBV infection, (3) management of chronically infected persons, and (4) treatment of chronic hepatitis B. Management of hepatitis B in patients waiting for liver transplantation and prevention of recurrent hepatitis B post-liver transplant have been covered in a recent review article and will not be discussed in these guidelines. ${ }^{12}$

\section{Screening High Risk Populations to Identify HBV Infected Persons}

The global prevalence of $\mathrm{HBsAg}$ varies greatly and countries can be defined as having a high, intermediate and low prevalence of $\mathrm{HBV}$ infection based on a prevalence of $\mathrm{HBsAg}$ carriers of $\geq 8 \%, 2 \%-7 \%$, and $<2 \%$ respectively. $7,9,13,14$ In developed countries, the prevalence is higher among those who immigrated from high or intermediate prevalence countries and in those with high risk behaviors. ${ }^{7,9}$

$\mathrm{HBV}$ is transmitted by perinatal, percutaneous, and sexual exposure, as well as by close person-to-person contact presumably by open cuts and sores, especially among children in hyperendemic areas. ${ }^{9}$ HBV can survive out- 
Table 1. Quality of Evidence on Which a Recommendation is Based

\begin{tabular}{ll}
\hline Grade & \multicolumn{1}{c}{ Definition } \\
\hline I & Randomized controlled trials \\
II-1 & Controlled trials without randomization \\
II-2 & Cohort or case-control analytic studies \\
II-3 & Multiple time series, dramatic uncontrolled experiments \\
III & Opinions of respected authorities, descriptive epidemiology \\
\hline
\end{tabular}

side the body for prolonged periods. ${ }^{15,16}$ The risk of developing chronic $\mathrm{HBV}$ infection after acute exposure ranges from $90 \%$ in newborns of $\mathrm{HBeAg}$-positive mothers to $25 \%$ to $30 \%$ in infants and children under 5 and to less than $5 \%$ in adults. ${ }^{17-21}$ In addition, immunosuppressed persons are more likely to develop chronic HBV infection after acute infection. ${ }^{22,23}$ In countries such as the United States where most of the infants, children, and adolescents have been vaccinated against $\mathrm{HBV}$, the risk of transmitting $\mathrm{HBV}$ in daycare centers or schools is extremely low and $\mathrm{HBs} A g$-positive children should not be isolated or prevented from participating in activities including sports.

Table 2 displays the population and high risk groups that should be screened for HBV infection and immunized if seronegative. The tests used to screen persons for HBV should include HBsAg and hepatitis B surface antibody (anti-HBs). Alternatively, hepatitis B core antibody (anti-HBc) can be utilized as long as those who test positive are further tested for both HBsAg and anti-HBs to differentiate infection from immunity.

Some persons may test positive for anti-HBc but not $\mathrm{HBsAg}$ or anti-HBs. The finding of isolated anti-HBc can occur for a variety of reasons. (1) Anti-HBc may be an indicator of chronic HBV infection; in these persons, $\mathrm{HBsAg}$ had decreased to undetectable levels but HBV DNA often remains detectable, more so in the liver than in serum. This situation is not uncommon among persons from areas with high prevalence of HBV infection and in those with human immunodeficiency virus (HIV) or hepatitis $\mathrm{C}$ virus (HCV) infection. ${ }^{24}$ (2) Anti-HBc may be a marker of immunity after recovery from a prior infection. In these persons, anti-HBs had decreased to undetectable levels but anamnestic response can be observed after one dose of HBV vaccine. ${ }^{25}$ (3) Anti-HBc may be a false positive test result particularly in persons from low prevalence areas with no risk factors for HBV infection. These individuals respond to hepatitis $B$ vaccination similar to persons without any HBV seromarkers.9,25,26 (4) Anti-HBc may be the only marker of HBV infection during the window phase of acute hepatitis B; these persons should test positive for anti-HBc IgM.

\section{Recommendations for Persons Who Should Be Tested for $H B V$ Infection:}

1. The following groups should be tested for HBV infection: persons born in hyperendemic areas (Table 2), men who have sex with men, persons who have ever used injecting drugs, dialysis patients, HIV-infected individuals, pregnant women, and family members, household members, and sexual contacts of HBV-infected persons. Testing for $\mathrm{HBsAg}$ and anti-HBs should be performed, and seronegative persons should be vaccinated. (I)

\section{Counseling and Prevention of Hepatitis B}

Patients with chronic HBV infection should be counseled regarding lifestyle modifications and prevention of transmission and the importance of life long monitoring. No specific dietary measures have been shown to have any effect on the progression of chronic hepatitis B. However, heavy use of alcohol $(>20 \mathrm{~g} / \mathrm{d}$ in women and $>30 \mathrm{~g} / \mathrm{d}$ in men) may be a risk factor for the development of cirrhosis. ${ }^{27,28}$

Carriers of HBV should be counseled regarding transmission to others (see Table 3). Household members and

\section{Table 2. Groups at High Risk for HBV Infection Who Should} Be Screened $^{9}$

\footnotetext{
- Individuals born in areas of high ${ }^{\#}$ and intermediate prevalence rates $^{\dagger}$ for HBV including immigrants and adopted children^*

-South Asia (except Sri Lanka)

-Africa

-South Pacific Islands

-Middle East (except Cyprus)

-European Mediterranean: Greece, Italy, Malta, Portugal and Spain

-The Arctic (indigenous populations)

-South America: Argentina, Bolivia, Brazil, Ecuador, Guyana, Suriname,

Venezuela and Amazon region of Colombia and Peru

-Independent states of former Soviet Union

-Eastern Europe, including Russia, except Hungary

-Caribbean: Antigua and Barbuda, Dominica, Dominican Republic, Granada, Haiti, Jamaica, Puerto Rico, St. Kitts and Nevis, St. Lucia, St. Vincent and Grenadines, Trinidad and Tobago and Turks and Caicos.

- Other high risk groups recommended for screening

-Household and sexual contacts of HBsAg-positive persons*

-Persons who have ever injected drugs*

-Persons with multiple sexual partners or history of sexually transmitted disease*

-Men who have sex with men*

-Inmates of correctional facilities*

-Individuals with chronically elevated ALT or AST*

-Individuals infected with HCV or HIV*

-Patients undergoing renal dialysis*

-All pregnant women
}

NIf HBsAg-positive persons are found in the first generation, subsequen generations should be tested

\#HBsAg prevalence $>8 \%$

†HBsAg prevalence $2 \%-7 \%$

*Those who are seronegative should receive hepatitis $B$ vaccine 
Table 3. Recommendations for Infected Persons Regarding Prevention of Transmission of HBV to Others

Persons who are HBsAg-positive should

- Have sexual contacts vaccinated

- Use barrier protection during sexual intercourse if partner not vaccinated or naturally immune

- Not share toothbrushes or razors

- Cover open cuts and scratches

- Clean blood spills with detergent or bleach

- Not donate blood, organs or sperms

Children and adults who are HBsAg-positive:

- Can participate in all activities including contact sports

- Should not be excluded from daycare or school participation and should not be isolated from other children

- Can share food, utensils or kiss others

steady sexual partners are at increased risk of $\mathrm{HBV}$ infection and therefore should be vaccinated if they test negative for HBV serologic markers. ${ }^{9}$ For casual sex partners or steady partners who have not been tested or have not completed the full immunization series, barrier protection methods should be employed. HBsAg-positive women who are pregnant should be counseled to make sure they inform their providers so hepatitis B immune globulin (HBIG) and hepatitis B vaccine can be administered to their newborn immediately after delivery. ${ }^{9} \mathrm{HBIG}$ and concurrent hepatitis $B$ vaccine have been shown to be $95 \%$ efficacious in the prevention of perinatal transmission of $\mathrm{HBV}$, the efficacy is lower for maternal carriers with very high serum HBV DNA levels $\left(>8 \log _{10}\right.$ IU/ $\mathrm{ml}) .9,29$ Transmission of HBV from infected health care workers to patients has also been shown to occur in rare instances. ${ }^{30,31}$ For HBV carriers who are health care workers, the Centers for Disease Control and Prevention recommends that those who are $\mathrm{HBeAg}$-positive should not perform exposure prone procedures without prior counseling and advice from an expert review panel regarding under what circumstances, if any, they should be allowed to perform these procedures. ${ }^{32}$ These circumstances would include notifying prospective patients of their $\mathrm{HBV}$ status prior to procedures. While the CDC does not use serum HBV DNA levels as criteria for restriction of clinical procedures, several European countries use a threshold level varying from 200 to $20,000 \mathrm{IU} / \mathrm{ml}$ to determine if $\mathrm{HBsAg}$-positive health care workers are allowed to perform exposure prone procedures. ${ }^{33,34}$

The risk of infection after blood transfusion and transplantation of non-hepatic solid organs (kidneys, lungs, heart) from persons with isolated anti-HBc is low: $0 \%$ to $13 \% .{ }^{35}$ The risk of infection after transplantation of liver from $\mathrm{HBs} A g$-negative, anti-HBc-positive donors has been reported to be as high as $75 \%$ and is related to the HBV immune status of the recipients. ${ }^{36,37}$ If anti-HBcpositive donor organs are used for HBV seronegative re- cipients, antiviral therapy should be administered to prevent de novo HBV infection. While the optimal duration of prophylactic therapy has not been determined, a limited duration such as 6-12 months may be sufficient for transplantation of non-hepatic solid organs. For transplantation of livers, life-long antiviral therapy is recommended, but whether HBIG is necessary is unclear. ${ }^{38}$

\section{Hepatitis B Vaccination}

Recommendations for vaccination are outlined in a recent CDC and Advisory Committee on Immunization Practices (ACIP) guideline. ${ }^{9,9 a}$ Follow-up testing is recommended for those who remain at risk of infection such as health care workers, infants of $\mathrm{HBsAg}$-positive mothers and sexual partners of persons with chronic HBV infection. Furthermore, annual testing of hemodialysis patients is recommended since immunity wanes rapidly in these individuals who are at a high risk of continued exposure to HBV.

Recommendations for Counseling and Prevention of Transmission of Hepatitis B from Individuals with Chronic HBV Infection:

2. Carriers should be counseled regarding prevention of transmission of HBV (Table 3). (III)

3. Sexual and household contacts of carriers who are negative for HBV seromarkers should receive hepatitis $B$ vaccination. (III)

4. Newborns of HBV-infected mothers should receive HBIG and hepatitis $B$ vaccine at delivery and complete the recommended vaccination series. (I)

5. Persons who remain at risk for $\mathrm{HBV}$ infection such as infants of $\mathrm{HBsAg}$-positive mothers, health care workers, dialysis patients, and sexual partners of carriers should be tested for response to vaccination. (III)

- Postvaccination testing should be performed at 9 to 15 months of age in infants of carrier mothers and 1-2 months after the last dose in other persons. (III)

- Follow-up testing of vaccine responders is recommended annually for chronic hemodialysis patients. (III)

6. Abstinence or only limited use of alcohol is recommended in hepatitis B carriers. (III)

7. Persons who are positive only for anti-HBc and who are from a low endemic area with no risk factors for $\mathrm{HBV}$ should be given the full series of hepatitis $B$ vaccine. (II-2)

\section{HBV Genotypes}

Eight genotypes of HBV have been identified labeled A through H. ${ }^{39,40}$ The prevalence of HBV genotypes varies depending on the geographical location. All known HBV genotypes have been found in the United States, with the 
prevalence of genotypes A, B, C, D and E-G being 35\%, $22 \%, 31 \%, 10 \%$, and $2 \%$, respectively. ${ }^{41}$

Recent data suggest that HBV genotypes may play an important role in the progression of HBV-related liver disease as well as response to interferon therapy. ${ }^{39}$ Studies from Asia found that HBV genotype B is associated with $\mathrm{HBeAg}$ seroconversion at an earlier age, more sustained remission after $\mathrm{HBeAg}$ seroconversion, less active hepatic necroinflammation, a slower rate of progression to cirrhosis, and a lower rate of HCC development compared to genotype C. ${ }^{42-47}$ The relation between other HBV genotypes and liver disease progression is unclear.

Several studies of standard interferon-alpha (IFN- $\alpha$ ) and one study of pegylated IFN-alpha (pegIFN- $\alpha$ ) therapy showed that genotypes $A$ and $B$ were associated with higher rates of $\mathrm{HBeAg}$ seroconversion compared to genotypes $C$ and D. ${ }^{48-51}$ Another study of pegIFN- $\alpha$ reported that genotype $\mathrm{A}$ but not genotype $\mathrm{B}$ was associated with a higher rate of $\mathrm{HBeAg}$ seroconversion. ${ }^{52}$ Studies of nucleos $(\mathrm{t})$ ide analogue (NA) therapies have not shown any relation between HBV genotypes and response. Thus, additional data on the relation between HBV genotypes and treatment response are needed before testing for $\mathrm{HBV}$ genotypes in clinical practice is recommended.

\section{Terminology and Natural History of Chronic HBV Infection}

The consensus definition and diagnostic criteria for clinical terms relating to $\mathrm{HBV}$ infection adopted at the National Institutes of Health (NIH) conferences on Management of Hepatitis B in 2000 and 2006 are summarized in Table 4. ${ }^{3,4}$

During the initial phase of chronic HBV infection, serum HBV DNA levels are high and $\mathrm{HBeAg}$ is present. The majority of carriers eventually loses $\mathrm{HBeAg}$ and develop antibody to $\mathrm{HBeAg}$ (anti-HBe). 13,53-56

Among individuals with perinatally acquired $\mathrm{HBV}$ infection, a large percent of $\mathrm{HBeAg}$-positive patients have high serum HBV DNA but normal ALT levels. ${ }^{77,58}$ These patients are considered to be in the "immune tolerant" phase. Many of these patients develop HBeAg-positive chronic hepatitis B with elevated ALT levels in later life. ${ }^{56,59,60}$ In sub-Saharan Africa, Alaska, and Mediterranean countries, transmission of HBV usually occurs from person to person during childhood. ${ }^{20,61-63}$ In these populations most children who are $\mathrm{HBeAg}$ positive have elevated ALT levels and seroconversion to anti-HBe is common near or shortly after the onset of puberty. In developed countries, HBV infection is usually acquired during adulthood through sexual transmission and injecting drug use. $8,9,64$ Very little longitudinal data are avail-
Table 4. Glossary of Clinical Terms Used in HBV Infection

\section{Definitions}

Chronic hepatitis $B$

Chronic necroinflammatory disease of the liver caused by persistent infection with hepatitis B virus. Chronic hepatitis B can be subdivided into $\mathrm{HBeAg}$ positive and $\mathrm{HBeAg}$ negative chronic hepatitis $\mathrm{B}$.

Inactive HBsAg carrier state

Persistent HBV infection of the liver without significant, ongoing necroinflammatory disease

Resolved hepatitis $B$

Previous HBV infection without further virologic, biochemical or histological evidence of active virus infection or disease

Acute exacerbation or flare of hepatitis $B$

Intermittent elevations of aminotransferase activity to more than 10 times the upper limit of normal and more than twice the baseline value

Reactivation of hepatitis $B$

Reappearance of active necroinflammatory disease of the liver in a person known to have the inactive HBsAg carrier state or resolved hepatitis $B$

HBeAg clearance

Loss of $\mathrm{HBeAg}$ in a person who was previously $\mathrm{HBeAg}$ positive

HBeAg seroconversion

Loss of HBeAg and detection of anti-HBe in a person who was previously $\mathrm{HBeAg}$ positive and anti-HBe negative

$H B$ Ag reversion

Reappearance of $\mathrm{HBeAg}$ in a person who was previously $\mathrm{HBeAg}$ negative, anti-HBe positive

Diagnostic criteria

Chronic hepatitis $B$

1. HBsAg $+>6$ months

2. Serum HBV DNA $>20,000 \mathrm{IU} / \mathrm{ml}\left(10^{5}\right.$ copies/ml), lower values 2,000 $20,000 \mathrm{IU} / \mathrm{ml}\left(10^{4}-10^{5}\right.$ copies/ml) are often seen in HBeAg-negative chronic hepatitis $\mathrm{B}$

3. Persistent or intermittent elevation in ALT/AST levels

4. Liver biopsy showing chronic hepatitis with moderate or severe necroinflammation

Inactive HBsAg carrier state

1. $\mathrm{HBsAg}+>6$ months

2. HBeAg-, anti-HBe+

3. Serum HBV DNA $<2,000 \mathrm{IU} / \mathrm{ml}$

4. Persistently normal ALT/AST levels

5. Liver biopsy confirms absence of significant hepatitis

Resolved hepatitis $B$

1. Previous known history of acute or chronic hepatitis $B$ or the presence of anti-HBc \pm anti-HBs

2. $\mathrm{HBSAg}-$

3. Undetectable serum HBV DNA\#

4. Normal ALT levels

\#Very low levels may be detectable using sensitive PCR assays

able, but liver disease is generally present in persons with high HBV DNA levels.

Among carriers with elevated ALT levels, the rate of clearance of $\mathrm{HBeAg}$ averages between $8 \%$ and $12 \%$ per year ${ }^{53-56,65}$ but is much lower in carriers who are in the immune tolerant phase (mostly Asian children and young adults with normal ALT levels) ${ }^{57,58}$ and in immunocompromised subjects. ${ }^{23,66} \mathrm{HBeAg}$ clearance may follow an exacerbation of hepatitis, manifested by an elevation of ALT levels. ${ }^{54,56}$ Older age, higher ALT, and HBV genotype B (vs. C) are associated with higher rates of spontaneous $\mathrm{HBeAg}$ clearance. 
After spontaneous $\mathrm{HBeAg}$ seroconversion, $67 \%$ to $80 \%$ of carriers have low or undetectable HBV DNA and normal ALT levels with minimal or no necroinflammation on liver biopsy - the "inactive carrier state." $13,53-56,62,65,67$ Approximately 4\% to $20 \%$ of inactive carriers have one or more reversions back to $\mathrm{HBeAg}$. Among those who remain anti-HBe positive, $10 \%$ to $30 \%$ continue to have elevated ALT and high HBV DNA levels after $\mathrm{HBeAg}$ seroconversion, and roughly $10 \%$ to $20 \%$ of inactive carriers may have reactivation of $\mathrm{HBV}$ replication and exacerbations of hepatitis after years of quiescence. ${ }^{56,60,65,67,68}$ Therefore, serial testing is necessary to determine if an $\mathrm{HBsAg}$-positive, $\mathrm{HBeAg}$-negative carrier is truly in the "inactive carrier state" and life long follow-up is required to confirm that the inactive state is maintained. Clearance of $\mathrm{HBeAg}$, whether spontaneous or after antiviral therapy, reduces the risk of hepatic decompensation and improves survival. ${ }^{69-77}$

Moderate or high levels of persistent HBV replication or reactivation of $\mathrm{HBV}$ replication following a period of quiescence after $\mathrm{HBeAg}$ seroconversion leads to $\mathrm{HBeAg}$ negative chronic hepatitis $\mathrm{B}$, which is characterized by HBV DNA levels $>2,000 \mathrm{IU} / \mathrm{ml}$ and continued necroinflammation in the liver. ${ }^{78}$ Most patients with $\mathrm{HBeAg}$-negative chronic hepatitis $\mathrm{B}$ harbor $\mathrm{HBV}$ variants in the precore or core promoter region. ${ }^{79-85}$ Patients with $\mathrm{HBeAg}$-negative chronic hepatitis B tend to have lower serum HBV DNA levels than those with $\mathrm{HBeAg}$-positive chronic hepatitis B (2,000-20 million vs. 200,000-2 billion $\mathrm{IU} / \mathrm{ml}$ ) and are more likely to run a fluctuating course. These patients are also older and have more advanced liver disease since HBeAg-negative chronic hepatitis $B$ represents a later stage in the course of chronic HBV infection. ${ }^{78,83,86}$

Approximately $0.5 \%$ of $\mathrm{HBsAg}$ carriers will clear HBsAg yearly; most will develop anti-HBs. ${ }^{65,87}$ However, low levels of HBV DNA remain detectable in the serum in up to half of these persons. The prognosis is improved in carriers who cleared $\mathrm{HBsAg}$ but $\mathrm{HCC}$ has been reported years after clearance of $\mathrm{HBsAg}$, particularly in those who were older or had progressed to cirrhosis before HBsAg clearance. ${ }^{65,87-91}$

\section{Factors Associated with Progression of HBV-related Liver Disease}

Host and viral risk factors associated with increased rates of cirrhosis include older age (longer duration of infection), HBV genotype C, high levels of HBV DNA, habitual alcohol consumption, and concurrent infection with hepatitis $\mathrm{C}$ virus (HCV), hepatitis $\mathrm{D}$ virus (HDV) or human immunodeficiency virus (HIV). ${ }^{92,93}$ Environmental factors that are associated with an increase risk of cirrhosis or HCC include heavy alcohol consumption, carcinogens such as aflatoxin, and, more recently smoking.

Host and viral risk factors for HCC include male gender, family history of HCC, older age, history of reversions from anti-HBe to $\mathrm{HBeAg}$, presence of cirrhosis, $\mathrm{HBV}$ genotype $\mathrm{C}$, core promoter mutation, and coinfection with HCV. ${ }^{65,69,92,93}$ Although cirrhosis is a strong risk factor for HCC, 30\% to $50 \%$ of HCC associated with $\mathrm{HBV}$ occur in the absence of cirrhosis. ${ }^{11}$ Recently, several prospective follow-up studies of large cohorts of carriers from Asia found that the presence of $\mathrm{HBeAg}$ and high levels of HBV DNA were independent risk factors for the subsequent development of cirrhosis and HCC.47,94-97 Given that most of the carriers in these studies likely acquired HBV infection perinatally and their mean age at enrollment was around 40 years, these data indicate that high levels of HBV replication persisting for more than 4 decades are associated with an increased risk of HCC. However, due to the fluctuating nature of chronic HBV infection, the accuracy of one high HBV DNA level at a single time point in predicting the prognosis of individual carriers may be limited and the risk of HCC in a younger carrier who is $\mathrm{HBeAg}$-positive with one high HBV DNA level may be substantially lower.

\section{Co-infection with HCV, HDV or HIV}

$H C V$. Coexistent HCV infection has been estimated to be present in $10 \%$ to $15 \%$ of patients with chronic hepatitis $\mathrm{B}$ and is more common among injecting drug users. ${ }^{98}$ Acute coinfection with $\mathrm{HBV}$ and HCV may shorten the duration of $\mathrm{HBs}$ antigenemia and lower the peak serum aminotransferase concentrations compared with acute HBV infection alone. ${ }^{99,100}$ However, acute coinfection of HCV and HBV, or acute HCV on preexisting chronic HBV have also been reported to increase the risk of severe hepatitis and fulminant hepatic failure. ${ }^{101}$

Patients with dual HBV and HCV infection have a higher rate of cirrhosis and HCC development compared to patients infected by either virus alone. ${ }^{102,103}$

$H \boldsymbol{H} \boldsymbol{V}$. HDV is a satellite virus, which is dependent on $\mathrm{HBV}$ for the production of envelope proteins. ${ }^{104} \mathrm{HBV} /$ HDV coinfection most commonly occurs in the Mediterranean area and parts of South America. The availability of $\mathrm{HBV}$ vaccines and public health education on the prevention of transmission of HBV infection has led to a significant decline in the prevalence of $\mathrm{HDV}$ infection in the past decade. ${ }^{105} \mathrm{HDV}$ infection can occur in two forms. The first form is caused by the coinfection of HBV and HDV; this usually results in a more severe acute hepatitis with a higher mortality rate than is seen with acute 
hepatitis B alone, ${ }^{104,106}$ but rarely results in chronic infection. A second form is a result of a superinfection of HDV in a HBV carrier and can manifest as a severe "acute" hepatitis in previously asymptomatic HBV carriers or as an exacerbation of underlying chronic hepatitis $\mathrm{B}$. Unlike coinfection, HDV superinfection in HBV carriers almost always results in chronic infection with both viruses. A higher proportion of persons with chronic HBV/HDV coinfection develop cirrhosis, hepatic decompensation, and HCC compared to those with chronic HBV infection alone. ${ }^{107,108}$

HIV. Studies have found that between 6\% and 13\% of persons infected with HIV are also coinfected with HBV. Coinfection with HIV is more common in persons from regions where both viruses are endemic, such as sub-Saharan Africa. ${ }^{9}$ Individuals with HBV and HIV coinfection tend to have higher levels of HBV DNA, lower rates of spontaneous $\mathrm{HBeAg}$ seroconversion, more severe liver disease, and increased rates of liver related mortality. ${ }^{109-112}$ In addition, severe flares of hepatitis can occur in HIV co-infected patients with low CD4 counts who experience immune reconstitution after initiation of highly active antiretroviral therapy (HAART). ${ }^{110}$ Elevated liver enzymes in patients with HBV/HIV coinfection can be caused by other factors besides HBV including HAART and certain opportunistic infections such as cytomegalovirus and Mycobacterium Avium.

Patients with HIV infection can have high levels of HBV DNA and hepatic necroinflammation with anti$\mathrm{HBc}$ but not HBsAg, so called "occult HBV". ${ }^{110}$ Therefore it is prudent to test all HIV infected persons for both $\mathrm{HBsAg}$ and anti-HBc and if either is positive, to test for HBV DNA. Persons who are negative for all HBV seromarkers should receive hepatitis $B$ vaccine. If feasible, hepatitis $\mathrm{B}$ vaccine should be given when $\mathrm{CD} 4$ cell counts are $>200 / \mathrm{ul}$ as response to vaccine is poor below this level. Persons with CD4 counts below 200 should receive HAART first and HBV vaccine when CD4 counts rise above 200/uL. ${ }^{110,111}$

\section{Evaluation and Management of Patients with Chronic HBV Infection}

\section{Initial Evaluation}

The initial evaluation of patients with chronic HBV infection should include a thorough history and physical examination, with special emphasis on risk factors for coinfection, alcohol use, and family history of HBV infection and liver cancer. Laboratory tests should include assessment of liver disease, markers of HBV replication, and tests for coinfection with HCV, HDV, or HIV in those at risk (Table 5). Vaccination for hepatitis A should

\section{Table 5. Evaluation of Patients with Chronic HBV Infection}

Initial evaluation

1. History and physical examination

2. Family History of liver disease, HCC

3. Laboratory tests to assess liver disease-complete blood counts with platelets, hepatic panel and prothrombin time

4. Tests for HBV replication-HBeAg/anti-HBe, HBV DNA

5. Tests to rule out viral coinfections-anti-HCV, anti-HDV (in persons from countries where HDV infection is common and in those with history of injection drug use), and anti-HIV in those at risk

6. Tests to screen for HCC-AFP at baseline and, in high risk patients, ultrasound

7. Consider liver biopsy to grade and stage liver disease - for patients who meet criteria for chronic hepatitis

Suggested follow-up for patients not considered for treatment

HBeAg+, HBV DNA > 20,000 IU/ml and normal ALT

- ALT q 3-6 months, more often if ALT becomes elevated

- If ALT levels are between 1-2 $\times$ ULN, recheck ALT q1-3 months; consider liver biopsy if age $>40$, ALT borderline or mildly elevated on serial tests. Consider treatment if biopsy shows moderate/severe inflammation or significant fibrosis

- If ALT $>2 \times$ ULN for 3-6 months and HBeAg+, HBV DNA $>20,000$ IU/ $\mathrm{ml}$, consider liver biopsy and treatment.

- Consider screening for HCC in relevant population

Inactive HBsAg carrier state

- ALT q 3 months for 1 year, if persistently normal, ALT q 6-12 months

- If ALT > 1-2 × ULN, check serum HBV DNA level and exclude other causes of liver disease. Consider liver biopsy if ALT borderline or mildly elevated on serial tests or if HBV DNA persistently $>20,000 \mathrm{IU} / \mathrm{ml}$. Consider treatment if biopsy shows moderate/severe inflammation or significant fibrosis

- Consider screening for HCC in relevant population

be administered to persons with chronic hepatitis $\mathrm{B}$ as per Centers for Disease Control recommendations. ${ }^{113}$

\section{$H B V$ DNA Assays}

Most HBV DNA assays used in clinical practice are based on polymerase chain reaction (PCR) amplification with lower limits of detection of 50-200 IU/ml (250$1,000$ copies $/ \mathrm{ml}),{ }^{114}$ and a limited dynamic range, up to 4-5 $\log _{10} \mathrm{IU} / \mathrm{ml}$. Recently, HBV DNA assays that utilize real-time PCR technology with improved sensitivity (5-10 IU/ml) and wider dynamic range (up to $8-9 \log _{10}$ $\mathrm{IU} / \mathrm{ml}$ ) have become available. ${ }^{15}$ Quantification of serum HBV DNA is a crucial component in the evaluation of patients with chronic HBV infection and in the assessment of the efficacy of antiviral treatment.

A major dilemma in the interpretation of serum HBV DNA levels is the determination of cutoff values used to define treatment indications and response. Because HBV DNA persists even in persons who have serological recovery from acute HBV infection, ${ }^{116}$ low levels of HBV DNA may not be associated with progressive liver disease and viral clearance is an unrealistic treatment endpoint. An arbitrary value of $20,000 \mathrm{IU} / \mathrm{ml}\left(>10^{5}\right.$ copies $\left./ \mathrm{ml}\right)$ was chosen as a diagnostic criterion for chronic hepatitis $\mathrm{B}$ at the 2000 NIH conference. ${ }^{3}$ However, chronic hepatitis, 
cirrhosis and HCC have been found in patients with lower HBV DNA levels. Also, some patients with chronic hepatitis B have widely fluctuating HBV DNA levels that may vary from undetectable to $>2,000,000 \mathrm{IU} / \mathrm{ml} .{ }^{117}$ Thus, serial monitoring of HBV DNA levels is more important than any single arbitrary cutoff value in prognostication and in determining the need for treatment. It is now recognized that lower HBV DNA levels $\left(3-5 \log _{10}\right.$ $\mathrm{IU} / \mathrm{ml}$ ) may be associated with progressive liver disease and may warrant treatment, particularly in those who are HBeAg-negative or have already developed cirrhosis.

\section{Liver Biopsy}

The purpose of a liver biopsy is to assess the degree of liver damage and to rule out other causes of liver disease. However, it must be recognized that liver histology can improve significantly in patients who have sustained response to antiviral therapy or spontaneous HBeAg seroconversion. Liver histology also can worsen rapidly in patients who have recurrent exacerbations or reactivations of hepatitis.

Liver biopsy is most useful in persons who do not meet clear cut guidelines for treatment listed below. Recent studies suggest that the upper limits of normal for ALT and AST should be decreased to $30 \mathrm{U} / \mathrm{l}$ for men and 19 U/l for women. ${ }^{118} \mathrm{HBV}$ infected patients with ALT values close to the upper limit of normal may have abnormal histology and can be at increased risk of mortality from liver disease especially those above age 40 . Thus, decisions on liver biopsy should take into consideration age, the new suggested upper limits of normal for ALT, HBeAg status, HBV DNA levels, and other clinical features suggestive of chronic liver disease or portal hypertension.

Recommendations for Initial Evaluation of Persons with Chronic HBV Infection:

8. Initial evaluation of persons newly diagnosed with chronic HBV infection should include history, physical examination and laboratory testing as outlined in Table 5. (III)

9. All persons with chronic hepatitis B not immune to hepatitis A should receive 2 doses of hepatitis A vaccine 6 to 18 months apart. (II-3)

\section{Follow-up of Patients Not Initially Considered for Treatment}

HBeAg-Positive Patients with High Serum HBV DNA but Normal ALT Levels. These patients should be monitored at 3 to 6 month intervals (Table 5, Fig. 1). More frequent monitoring should be performed when ALT levels become elevated. ${ }^{4,56,60,119}$ Patients who remain $\mathrm{HBeAg}$ positive with HBV DNA levels greater than
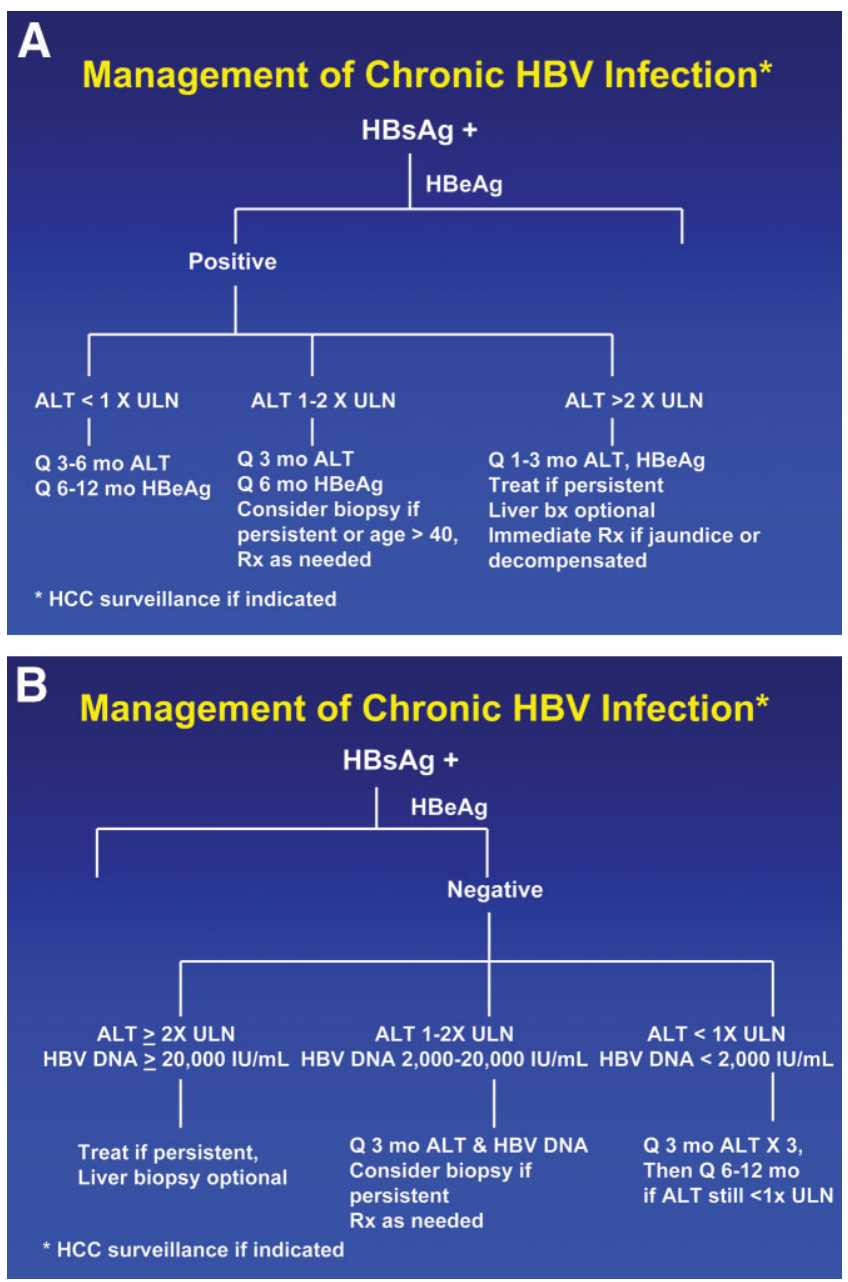

Fig. 1. Algorithm for follow-up of HBV carriers who are HBeAg-positive (A) or HBeAg-negative (B). ALT, alanine aminotransferase; ULN, upper limit of normal; Rx, treat; HCC, hepatocellular carcinoma.

20,000 IU/ml after a 3 to 6 month period of elevated ALT levels greater than two times the upper limit of normal should be considered for liver biopsy and antiviral treatment (Fig. 1). Liver biopsy and treatment should also be considered in patients with persistent borderline normal or slightly elevated ALT levels particularly if the patient is above the age of 40 . Liver biopsy is usually not necessary in young patients (below 30) who are $\mathrm{HBeAg}$-positive and have persistently normal ALT.

HBeAg-negative, anti-HBe Positive Patients with Normal ALT Levels and HBV DNA <2,000IU/ml (Inactive HBsAg Carriers). These patients should be monitored with ALT determination every 3 months during the first year to verify that they are truly in the "inactive carrier state" and then every 6-12 months. ${ }^{86,117}$ If the ALT level is subsequently found to be elevated, more frequent monitoring is needed. In addition, an evaluation into the cause of ALT elevation, including HBV DNA 
tests, should be initiated if it persists or recurs (Table 5 , Fig. 1).

\section{Recommendations for Monitoring Patients with} Chronic HBV Infection (Fig. 1):

10. HBeAg-positive and HBeAg-negative patients who meet criteria for chronic hepatitis B (Table 4) should be evaluated for treatment. (I)

11. HBeAg-positive patients:

- HBeAg-positive patients with persistently normal ALT should be tested for ALT at 3-6 month intervals. ALT along with HBV DNA should be tested more often when ALT levels become elevated. HBeAg status should be checked every 6-12 months. (III)

- Patients who remain $\mathrm{HBeAg}$ positive with $\mathrm{HBV}$ DNA levels $>20,000 \mathrm{IU} / \mathrm{ml}$ after a 3-6 month period of elevated ALT levels between 1-2 $\times$ ULN, or who remain HBeAg positive with HBV DNA levels $>20,000 \mathrm{IU} / \mathrm{ml}$ and are $>40$ years old, should be considered for liver biopsy, and treatment should be considered if biopsy shows moderate/severe inflammation or significant fibrosis. (III) Patients who remain HBeAg positive with HBV DNA levels > 20,000 $\mathrm{IU} / \mathrm{ml}$ after a 3-6 month period of elevated ALT levels $>2 \times$ ULN should be considered for treatment. (III).

12. HBeAg-negative patients:

- HBeAg-negative patients with normal ALT and HBV DNA <2,000 IU $/ \mathrm{ml}$ should be tested for ALT every 3 months during the first year to verify that they are truly in the "inactive carrier state" and then every 6-12 months. (III)

- Tests for HBV DNA and more frequent monitoring should be performed if ALT or AST increases above the normal limit. (III)

Periodic Screening for HCC. A recent AASLD practice guideline on HCC has been published. ${ }^{120}$ Of the two tests prospectively evaluated as screening tools for HCC, alpha-fetoprotein (AFP) and ultrasound (US), the sensitivity, specificity, and diagnostic accuracy of US are higher than those of AFP. The AASLD Practice Guideline for HCC recommended surveillance of carriers at high risk of HCC with US every 6-12 months and AFP alone when US is not available or cost is an issue. ${ }^{120} \mathrm{Be}-$ cause the interpretation of US findings is operator dependent, clinicians may choose to employ both US and AFP for HCC surveillance.

\section{Recommendations for HCC Screening:}

13. HBV carriers at high risk for HCC such as Asian men over 40 years and Asian women over 50 years of age, persons with cirrhosis, persons with a family history of HCC, Africans over 20 years of age, and any
Table 6. Definition of Response to Antiviral Therapy of Chronic Hepatitis B
Category of response Biochemical (BR) Virologic (VR)

Virologic relapse

Histologic (HR)

Complete (CR)

Time of assessment

On-therapy

Maintained

End-of-treatment

Off-therapy

Sustained (SR-6)

Sustained (SR-12)
Decrease in serum ALT to within the normal range Decrease in serum HBV DNA to undetectable levels by PCR assays, and loss of HBeAg in patients who were initially $\mathrm{HBeAg}$ positive plicable to interferon therapy) Decrease in serum HBV DNA by $<2 \log _{10} \mathrm{IU} / \mathrm{ml}$ after at least 24 weeks of therapy

Increase in serum HBV DNA of $1 \log 10 \mathrm{IU} / \mathrm{ml}$ after discontinuation of treatment in at least two determinations more than 4 weeks apart Decrease in histology activity index by at least 2 points and no worsening of fibrosis score compared to pre-treatment liver biopsy

Fulfill criteria of biochemical and virological response and loss of $\mathrm{HBsAg}$ carrier over 40 years with persistent or intermittent ALT elevation and/or high HBV DNA level $>2,000$ $\mathrm{IU} / \mathrm{ml}$ should be screened with US examination every 6-12 months. (II-2)

14. For $\mathrm{HBV}$ carriers at high risk for $\mathrm{HCC}$ who are living in areas where US is not readily available, periodic screening with AFP should be considered. (II-2)

\section{Treatment of Chronic Hepatitis B}

The aims of treatment of chronic hepatitis B are to achieve sustained suppression of HBV replication and remission of liver disease. The ultimate goal is to prevent cirrhosis, hepatic failure and HCC. Parameters used to assess treatment response include normalization of serum ALT, decrease in serum HBV DNA level, loss of $\mathrm{HBeAg}$ with or without detection of anti-HBe, and improvement in liver histology. At the 2000 and 2006 NIH conferences on Management of Hepatitis B, it was proposed that responses to antiviral therapy of chronic hepatitis B be categorized as biochemical (BR), virologic (VR), or histologic (HR), and as on-therapy or sustained off-therapy (Table 6). ${ }^{3,4}$ Standardized definitions of primary nonresponse, breakthrough and relapse were also proposed. Currently, six therapeutic agents have been approved for the treatment of adults with chronic hepatitis B in the United States.

While IFNs are administered for predefined durations, NAs are usually administered until specific endpoints are 
Table 7. Definition of Terms Relating to Antiviral Resistance to Nucleoside Analogue (NA) Treatment

Virologic breakthrough Increase in serum HBV DNA by $>1 \log 10$ (10-fold) above nadir after achieving virologic response, during continued treatment

Viral rebound Increase in serum HBV DNA to $>20,000 \mathrm{IU} / \mathrm{ml}$ or above pretreatment level after achieving virologic response, during continued treatment

Biochemical breakthrough Increase in ALT above upper limit of normal after achieving normalization, during continued treatment

Genotypic resistance

Detection of mutations that have been shown in in vitro studies to confer resistance to the NA that is being administered

Phenotypic resistance

In vitro confirmation that the mutation detected decreases susceptibility (as demonstrated by increase in inhibitory concentrations) to the NA administered

achieved. The difference in approach is related to the additional immune modulatory effects of IFN. For $\mathrm{HBeAg}$-positive patients, viral suppression with currently approved treatments can be sustained in 50\%-90\% patients if treatment is stopped after $\mathrm{HBeAg}$ seroconversion is achieved. For HBeAg-negative patients, relapse is frequent even when HBV DNA has been suppressed to undetectable levels by PCR assays for more than a year; thus, the endpoint for stopping treatment is unclear.

\section{Antiviral Resistance}

A major concern with long-term NA treatment is the selection of antiviral-resistant mutations. The rate at which resistant mutants are selected is related to pretreatment serum HBV DNA level, rapidity of viral suppression, duration of treatment, and prior exposure to NA therapies. ${ }^{121}$ The incidence of genotypic resistance also varies with the sensitivity of the methods used for detection of resistant mutations and the patient population being tested. Table 7 summarizes the definition of terms commonly used in describing antiviral resistance.

Among the approved NA therapies for hepatitis B, lamivudine is associated with the highest and entecavir with the lowest rate of drug resistance in NA-naïve patients. The first manifestation of antiviral resistance is virologic breakthrough which is defined as a $>1 \log _{10}$ (10-fold) increase in serum HBV DNA from nadir during treatment in a patient who had an initial virologic response (Fig. 2). Up to $30 \%$ of virologic breakthrough observed in clinical trials is related to medication noncompliance, thus, compliance should be ascertained before testing for genotypic resistance. Serum HBV DNA levels tend to be low initially because most antiviral-resistant mutants have decreased replication fitness compared with wild-type HBV. ${ }^{122}$ However, compensatory muta- tions that can restore replication fitness frequently emerge during continued treatment leading to a progressive increase in serum HBV DNA that may exceed pretreatment levels. Virologic breakthrough is usually followed by biochemical breakthrough, which is defined as elevation in ALT during treatment in a patient who had achieved initial response. Emergence of antiviral-resistant mutations can lead to negation of the initial response, and in some cases hepatitis flares and hepatic decompensation. Antiviral-resistant mutations can be detected months and sometimes years before biochemical breakthrough. Thus, early detection and intervention can prevent hepatitis flares and hepatic decompensation, and this is particularly important in patients who are immunosuppressed and those with underlying cirrhosis. Another potential consequence of antiviral-resistant mutations is cross-resistance with other NAs, thus limiting future treatment options. Recently, there have also been reports of multi-drug resistant mutants in patients who have received sequential NA monotherapy. ${ }^{123,124}$

Judicious use of NA in patients with chronic hepatitis $\mathrm{B}$ is the most effective prophylaxis against the development of antiviral-resistant HBV. Thus, patients with minimal disease and those who are unlikely to achieve sustained response should not be treated with NA, particularly if they are young ( $<30$ years). When possible, the most potent NA with the lowest rate of genotypic resistance should be administered and compliance reinforced. Although combination therapy has been shown to pre-

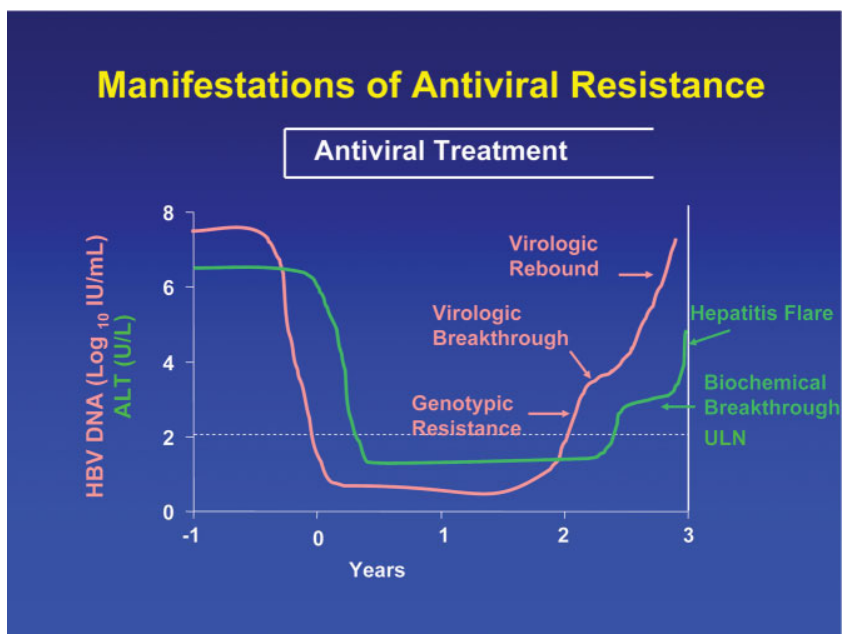

Fig. 2. Serial changes in serum HBV DNA and ALT levels in association with emergence of antiviral-resistant HBV mutants. The first manifestation of antiviral resistance is the detection of resistant mutations (genotypic resistance). Resistant mutations may be detected at the same time or prior to virologic breakthrough (increase in serum HBV DNA by $>1 \log$ above nadir). With time, serum HBV DNA levels continue to increase (viral rebound) and ALT become abnormal (biochemical breakthrough). In some patients, emergence of antiviral resistance leads to a marked increase in ALT (hepatitis flare). ALT, alanine aminotransferase. 
Table 8. Responses to Approved Antiviral Therapies Among Treatment-naive Patients with HBeAg Positive Chronic Hepatitis B

\begin{tabular}{|c|c|c|c|c|c|c|c|c|c|c|}
\hline & $\begin{array}{l}\text { Standard IFN- } \alpha \\
5 \mathrm{MU} \text { qd or } \\
10 \mathrm{MU} \text { tiw } \\
12-24 \mathrm{wk}\end{array}$ & Control & $\begin{array}{l}\text { Lamivudine } \\
100 \mathrm{mg} \text { qd } \\
48-52 \mathrm{wk}\end{array}$ & Placebo & $\begin{array}{l}\text { Adefovir } \\
10 \mathrm{mg} \mathrm{qd} \\
48 \mathrm{wk}\end{array}$ & Placebo & $\begin{array}{l}\text { Entecavir } \\
0.5 \mathrm{mg} \mathrm{qd} \\
48 \mathrm{wk}\end{array}$ & $\begin{array}{l}\text { Telbivudine } \\
600 \mathrm{mg} \text { qd } \\
52 \mathrm{wk}\end{array}$ & $\begin{array}{c}\text { PegIFN } \alpha \\
180 \mathrm{mcg} q w \\
48 \mathrm{wk}\end{array}$ & $\begin{array}{c}\text { PegIFN } \alpha+ \\
\text { Lamivudine } \\
180 \text { mcg qw+ } \\
100 \text { mg } 48 \text { wk }\end{array}$ \\
\hline \multicolumn{11}{|l|}{ Loss of serum } \\
\hline HBV DNA* & $37 \%$ & $17 \%$ & $40-44 \%$ & $16 \%$ & $21 \%$ & 0 & $67 \%$ & $60 \%$ & $25 \%$ & $69 \%$ \\
\hline $\begin{array}{l}\text { Loss of HBeAg } \\
\text { HBeAg }\end{array}$ & $33 \%$ & $12 \%$ & $17-32 \%$ & $6-11 \%$ & $24 \%$ & $11 \%$ & $22 \%$ & $26 \%$ & 30\%/34\%@ & 27\%/28\%@ \\
\hline seroconversion & \multicolumn{2}{|c|}{ Difference of $18 \%$} & $16-21 \%$ & $4-6 \%$ & $12 \%$ & $6 \%$ & $21 \%$ & $22 \%$ & 27\%/32\%@ & 24\%/27\%@ \\
\hline $\begin{array}{l}\text { Loss of HBsAg } \\
\text { Normalization }\end{array}$ & $7.8 \%$ & $1.8 \%$ & $<1 \%$ & 0 & 0 & 0 & $2 \%$ & $0 \%$ & $3 \%$ & $3 \%$ \\
\hline $\begin{array}{l}\text { of ALT } \\
\text { Histologic }\end{array}$ & \multicolumn{2}{|c|}{ Difference of $23 \%$} & $41-75 \%$ & $7-24 \%$ & $48 \%$ & $16 \%$ & $68 \%$ & $77 \%$ & $39 \%$ & $46 \%$ \\
\hline $\begin{array}{l}\text { improvement } \\
\text { Durability of }\end{array}$ & na & na & $49-56 \%$ & $23-25 \%$ & $53 \%$ & $25 \%$ & $72 \%$ & $65 \%$ & $38 \%^{\wedge}$ & $41 \%^{\wedge}$ \\
\hline response & $80-90 \%$ & & $50-80 \% \#$ & & 90\%\# & & $69 \% \#$ & $\sim 80 \%$ & na & \\
\hline
\end{tabular}

*Hybridization or branched chain DNA assays (lower limit of detection 20,000-200,000 IU/mI or 5-6 log copies/ml) in standard IFN- $\alpha$ studies and some lamivudine studies, and PCR assays (lower limit of detection approximately $50 \mathrm{lU} / \mathrm{ml}$ or 250 copies/ml) in other studies na $=$ not available @Responses at week 48 / week 72 (24 weeks after stopping treatment) \#Lamivudine and entecavir - no or short duration of consolidation treatment, Adefovir and telbivudine - most patients had consolidation treatment ^Post-treatment biopsies obtained at week 72

vent antiviral resistance in patients with HIV infection, the promise of combination therapy has not yet been fulfilled for patients with HBV infection.

Once antiviral-resistant HBV mutants have been selected, they are archived (retained in the virus population) even if treatment is stopped and lamivudine-resistant HBV mutants had been detected up to four years after withdrawal of lamivudine. ${ }^{124}$

\section{Interferon}

Interferons (IFNs) have antiviral, antiproliferative, and immunomodulatory effects. IFN- $\alpha$ has been shown to be effective in suppressing HBV replication and in inducing remission of liver disease. However, its efficacy is limited to a small percentage of highly selected patients.

\section{Efficacy in Various Categories of Patients.}

1. HBeAg-positive chronic hepatitis B with the following (Table 8):

a. Persistent or intermittent elevation in ALT. This pattern is seen frequently in chronic hepatitis B patients. Meta-analyses of randomized controlled trials found that a significantly higher percentage of IFN- $\alpha$-treated patients had a virologic response compared with untreated controls. ${ }^{125}$ High pretreatment ALT (greater than twice the upper limit of normal) and lower levels of serum HBV DNA are the most important predictors of a response to IFN- $\alpha$ therapy. ${ }^{126-128}$

b. Normal ALT. This pattern is usually seen in children or young adults with perinatally acquired $\mathrm{HBV}$ infection. $\mathrm{HBeAg}$ seroconversion occurs in less than $10 \%$ of these patients. ${ }^{128-131}$ c. Asian patients. Trials in Asian patients with $\mathrm{HBeAg}$ positive chronic hepatitis $B$ found that the response in patients with normal ALT was poor, ${ }^{131}$ but the response in patients with elevated ALT was similar to that in Caucasian patients. ${ }^{128}$

d. Children. The efficacy of IFN- $\alpha$ is similar to that in adults. ${ }^{132-135}$ However, most children, particularly those with perinatally acquired HBV infection have normal ALT and less than $10 \%$ of these children who received IFN- $\alpha$ cleared HBeAg. ${ }^{129,130}$

2. HBeAg-negative chronic hepatitis B (Table 9)

Results of four randomized controlled trials of IFN- $\alpha$ showed that the end-of-treatment response ranged from $38 \%$ to $90 \%$ in treated patients compared with only $0 \%$ to $37 \%$ of controls. ${ }^{136-139}$ However, approximately half of the responders relapse when therapy is discontinued, and relapses can occur up to 5 years post-therapy. ${ }^{140}$ Longer duration of treatment, 24 months verses 6-12 months, may increase the rate of sustained response. ${ }^{136,141}$

\section{Nonresponders to IFN- $\alpha$ treatment}

Most studies found that retreatment of IFN- $\alpha$ nonresponders with IFN- $\alpha$ alone was associated with a very low rate of response. Limited data suggest that 20\%-30\% $\mathrm{HBeAg}$-negative patients who relapsed or had no response during previous IFN- $\alpha$ treatment had a sustained response after a second course of IFN- $\alpha .{ }^{142}$

\section{Decompensated cirrhosis}

Approximately $20 \%$ to $40 \%$ of patients with $\mathrm{HBeAg}$ positive chronic hepatitis B develop a flare in their ALT 
Table 9. Responses to Approved Antiviral Therapies Among Treatment-naive Patients with HBeAg-Negative Chronic Hepatitis B

\begin{tabular}{|c|c|c|c|c|c|c|c|c|c|c|}
\hline & $\begin{array}{l}\text { Standard } \\
\text { IFN- } \alpha \\
5 \mathrm{Mu} \text { qd or } \\
10 \mathrm{MU} \text { tiw } \\
\text { 6-12 mo }\end{array}$ & Control & $\begin{array}{l}\text { Lamivudine } \\
100 \mathrm{mg} \text { qd } \\
48-52 \mathrm{wk}\end{array}$ & Placebo & $\begin{array}{l}\text { Adefovir } \\
10 \mathrm{mg} \mathrm{qd} \\
48 \mathrm{wk}\end{array}$ & Placebo & $\begin{array}{c}\text { Entecavir } \\
0.5 \mathrm{mg} \text { qd } \\
48 \mathrm{wk}\end{array}$ & $\begin{array}{l}\text { Telbivudine } \\
600 \mathrm{mg} \text { qd } \\
52 \mathrm{wk}\end{array}$ & $\begin{array}{c}\text { Peg IFN } \alpha \\
180 \mathrm{mcg} \text { qw } \\
48 \mathrm{wk}\end{array}$ & $\begin{array}{c}\text { PegIFN- } \alpha \\
180 \text { mcg qw+ } \\
\text { Lamivudine } \\
100 \mathrm{mg} \text { qd } \\
48 \mathrm{wk}\end{array}$ \\
\hline $\begin{array}{c}\text { Loss of serum } \\
\text { HBV DNA* }\end{array}$ & $60-70 \%$ & $10-20 \%$ & $60-73 \%$ & na & $51 \%$ & 0 & $90 \%$ & $88 \%$ & $63 \%$ & $87 \%$ \\
\hline $\begin{array}{l}\text { Normalization } \\
\text { of ALT }\end{array}$ & $60-70 \%$ & $10-20 \%$ & $60-79 \%$ & na & $72 \%$ & $29 \%$ & $78 \%$ & $74 \%$ & $38 \%$ & $49 \%$ \\
\hline $\begin{array}{l}\text { Histologic } \\
\text { improvement } \\
\text { Durability of } \\
\text { response }\end{array}$ & $10-20 \%$ & na & $60-66 \%$ & na & $64 \%$ & $33 \%$ & $70 \%$ & $67 \%$ & $48 \%^{\wedge}$ & $\begin{array}{l}38 \% \wedge \\
\sim 20 \%\end{array}$ \\
\hline
\end{tabular}

*Hybridization or branched chain DNA assays (lower limit of detection 20,000-200,000 IU/ml or 5-6 log copies/ml) in standard IFN- $\alpha$ studies and some lamivudine studies, and PCR assays (lower limit of detection approximately $50 \mathrm{IU} / \mathrm{ml}$ or $250 \mathrm{copies} / \mathrm{ml}$ ) in other studies

na $=$ not available

^Post-treatment biopsies obtained at week 72

values during IFN- $\alpha$ treatment. In patients with cirrhosis, the flare may precipitate hepatic decompensation. Two studies on IFN- $\alpha$ in patients with Child's class B or C cirrhosis reported minimal benefit. In addition, significant side effects due to bacterial infection and exacerbation of liver disease occurred even with low doses of IFN- $\alpha$ (3 MU every other day). ${ }^{143,144}$ However, clinical trials of HBeAg-positive chronic hepatitis that included patients with clinically and biochemically compensated cirrhosis found that the response was comparable to that in pre-cirrhotic patients and that less than $1 \%$ developed hepatic decompensation. ${ }^{127,128}$

Durability of Response and Long-term Outcome of IFN- $\boldsymbol{\alpha}$-treated Patients. IFN- $\alpha$-induced HBeAg clearance has been reported to be durable in $80 \%$ to $90 \%$ of patients after a follow-up period of 4 to 8 years. ${ }^{70,74-76,145-148}$ However, HBV DNA remained detectable in the serum from most of these patients when tested by PCR assays. Studies in Europe and the United States reported that delayed clearance of $\mathrm{HBsAg}$ occurred in $12 \%$ to $65 \%$ of patients within 5 years of $\mathrm{HBeAg}$ loss, but delayed $\mathrm{HBsAg}$ clearance was not observed in studies on Chinese patients. ${ }^{70,74-76,145-148}$ There has been only one report comparing the outcome of treated patients and controls. An 8-year follow-up of 101 male patients who participated in a controlled trial of IFN- $\alpha$ therapy in Taiwan found that treated patients had a lower incidence of HCC (1.5\% vs. $12 \%, P=$ $0.04)$ and a higher survival rate $(98 \%$ vs. $57 \%, P=0.02) .{ }^{75}$ However, long-term clinical benefits of IFN- $\alpha$ were not observed in another Asian study ${ }^{149}$ and the incidence of HCC in European or North American patients was not decreased. ${ }^{74,76}$ Studies comparing the outcome of responders versus nonresponders found that patients who cleared $\mathrm{HBeAg}$ had better overall survival and survival free of hepatic decompensation; the benefit was most apparent in patients with cirrhosis. $70,74,76,150$

Contrary to $\mathrm{HBeAg}$-positive patients, relapse after cessation of IFN- $\alpha$ treatment is frequent in $\mathrm{HBeAg-negative}$ patients, with sustained response rates of only $15 \%-30 \%$. Among the long-term responders, approximately $20 \%$ cleared HBsAg after 5 years of follow-up, and the risks of progression to cirrhosis, HCC, and liver-related deaths were reduced. ${ }^{86,140-142}$

Dose Regimen. IFN- $\alpha$ is administered as subcutaneous injections. The recommended dose for adults is $5 \mathrm{MU}$ daily or $10 \mathrm{MU}$ thrice weekly and for children $6 \mathrm{MU} / \mathrm{m}^{2}$ thrice weekly with a maximum of $10 \mathrm{MU}$. The recommended duration of treatment for patients with $\mathrm{HBeAg}$ positive chronic hepatitis B is 16 to 24 weeks. Current data suggest that patients with $\mathrm{HBeAg}$-negative chronic hepatitis B should be treated for at least 12 months, and one study suggested that 24 months treatment may increase the rate of sustained response. ${ }^{141}$

\section{Pegylated Interferon alfa (pegIFN- $\alpha$ )}

PegIFN- $\alpha$ has the advantages of more convenient administration and more sustained viral suppression. Clinical trials suggest that the efficacy of pegIFN- $\alpha$ is similar to or slightly better than standard IFN- $\alpha$.

\section{Efficacy in Various Categories of Patients}

1. HBeAg-positive chronic hepatitis (Table 8) - In one phase II trial, ${ }^{151}$ a higher percent of patients who received pegIFN- $\alpha$ had HBeAg seroconversion compared to those who received standard IFN- $\alpha$. In a subsequent phase III trial, 814 patients were randomized to receive pegIFN- $\alpha 2$ a 180 mcg weekly, pegIFN- $\alpha 2$ a $180 \mathrm{mcg}$ weekly + lamivudine $100 \mathrm{mg}$ daily, or lamivudine 100 mg daily for 48 weeks. ${ }^{52}$ At the end of treatment, viral 
suppression was most marked in the group that received combination therapy. Despite differences in the degree of viral suppression, $\mathrm{HBeAg}$ seroconversion was similar in the three groups at the end of treatment: $27 \%, 24 \%$, and $20 \%$, respectively, but significantly higher in the two groups that received pegIFN- $\alpha$ when response was assessed 24 weeks after treatment was stopped: 32\%, 27\%, and $19 \%$, respectively. These data indicate that pegIFN$\alpha 2 \mathrm{a}$ monotherapy was superior to lamivudine monotherapy in inducing sustained $\mathrm{HBeAg}$ seroconversion, and comparable to combination therapy of pegIFN- $\alpha 2$ a and lamivudine.

Similar results were reported in two trials in which pegIFN- $\alpha 2$ b was administered. Twenty-four weeks after treatment was stopped, one study reported identical rates (29\%) of $\mathrm{HBeAg}$ seroconversion in patients who received pegIFN- $\alpha 2 b$ with and without lamivudine, ${ }^{51}$ while the other study reported a significantly higher rate of $\mathrm{HBeAg}$ seroconversion in those who received the combination of pegIFN- $\alpha 2 \mathrm{~b}$ and lamivudine vs. those who received lamivudine only, $36 \%$ vs. $14 \% .{ }^{152}$

2. HBeAg-negative chronic hepatitis (Table 9) - In the only published report of peg IFN- $\alpha$ in HBeAg-negative patients, 552 patients were randomized to receive 48 weeks of pegIFN- $\alpha 2$ a 180 mcg weekly, the combination of pegIFN- $\alpha 2$ a 180 mcg weekly + lamivudine $100 \mathrm{mg}$ daily, or lamivudine $100 \mathrm{mg}$ daily. ${ }^{153}$ Viral suppression was most marked in the group that received combination therapy. However, sustained response (HBV DNA undetectable by PCR and normalization of ALT at week 72) was comparable in the groups that received pegIFN- $\alpha 2$ a alone or in combination with lamivudine, and superior to the group that received lamivudine monotherapy: $15 \%$, $16 \%$, and 6\%, respectively.

Dose Regimen. PegIFN- $\alpha 2 \mathrm{a}$ is the only pegylated interferon approved for the treatment of chronic hepatitis $\mathrm{B}$ in the United States. The recommended dose is 180 mcg weekly for 48 weeks. However, given the similarity in response rates between 90 and $180 \mathrm{mcg}$ doses in the phase II trial, and the comparable response rates between 24 and 48 week treatment in the phase II and phase III trials, ${ }^{52,151}$ it is possible that lower doses and/or shorter duration of treatment may suffice for $\mathrm{HBeAg}$-positive patients. Whether longer duration of treatment ( $>48$ week) will result in higher rates of sustained response in $\mathrm{HBeAg}$ negative patients remains to be determined.

Predictors of Response to Standard and PegIFN- $\alpha$. In $\mathrm{HBeAg}$-positive patients, the strongest predictor of $\mathrm{HBeAg}$ seroconversion to standard and pegIFN- $\alpha$ is the pretreatment ALT level. Other factors include high histologic activity index, low HBV DNA level, and more recently some studies have suggested that persons infected with HBV genotypes A and B respond better than those with genotypes $C$ and D. ${ }^{51,127,128}$ There is no consistent predictor of sustained response among $\mathrm{HBeAg-negative}$ patients.

Adverse Events. Standard IFN $-\alpha$ and pegIFN- $\alpha$ have similar side effect profiles. The most common side effect is an initial influenza-like illness: fever, chills, headache, malaise and myalgia. Other common side effects include fatigue, anorexia, weight loss and mild increase in hair loss. IFN- $\alpha$ has myelosuppressive effects but significant neutropenia $\left(<1000 / \mathrm{mm}^{3}\right)$ or thrombocytopenia $\left(<50,000 / \mathrm{mm}^{3}\right)$ are uncommon except in patients who have decreased cell counts prior to treatment. IFN- $\alpha$ treatment is accompanied by a flare in ALT in 30\%-40\% of patients. Hepatitis flares are considered to be an indicator of a favorable response but they can lead to hepatic decompensation, especially in patients with underlying cirrhosis. The most troublesome side effect of IFN- $\alpha$ is emotional lability: anxiety, irritability, depression and even suicidal tendency. IFN- $\alpha$ has been reported to induce the development of a variety of autoantibodies. In most instances, this is not accompanied by clinical illness. However, both hyper- and hypo-thyroidism that require treatment have been reported. Rarely, retinal changes and even impaired vision have been reported.

\section{Lamivudine (Epivir-HBV, 3TC)}

Lamivudine is the (-) enantiomer of $2^{\prime}-3^{\prime}$ dideoxy$3^{\prime}$-thiacytidine. Incorporation of the active triphosphate (3TC-TP) into growing DNA chains results in premature chain termination thereby inhibiting HBV DNA synthesis.

Efficacy in Various Categories of Patients. Lamivudine monotherapy is effective in suppressing HBV replication and in ameliorating liver disease. $\mathrm{HBeAg}$ seroconversion after a 1-year course of lamivudine treatment is similar to that of a 16-week course of standard IFN- $\alpha$ but lower than that of a 1-year course of pegIFN- $\alpha$.

1. HBeAg-positive chronic hepatitis B with the following (Table 8):

a. Persistent or intermittent elevation in ALT. Three clinical trials involving a total of 731 treatment naïve patients who received lamivudine for 1 year reported that $\mathrm{HBeAg}$ seroconversion occurred in $16 \%$ to $18 \%$ of patients compared with $4 \%$ to $6 \%$ of untreated controls. ${ }^{154-156}$ Histologic improvement defined as a reduction in necroinflammatory score by $\geq 2$ points was observed in $49 \%$ to $56 \%$ treated patients and in $23 \%$ to $25 \%$ of controls. HBeAg seroconversion rates increased with the duration of treatment to $50 \%$ after 5 years of continued treatment. ${ }^{157-160}$ 
b. Normal ALT levels. In patients with pretreatment ALT levels less than 2 times normal, the HBeAg seroconversion rate is less than $10 \%$ after 1 year and $19 \%$ after 3 years of treatment. ${ }^{161,162}$

c. Asian patients. Asians respond similarly to lamivudine as Caucasian patients. ${ }^{162}$

d. Children. In a 52 week randomized-control trial in children $\mathrm{HBeAg}$ seroconversion was observed in $22 \%$ of the lamivudine-treated children versus $13 \%$ placebo controls $(P=0.06) .{ }^{163} \mathrm{HBeAg}$ seroconversion increased to $34 \%$ after 2 years of continuous treatment. Lamivudineresistant $\mathrm{HBV}$ mutation was detected in $19 \%, 49 \%$ and $64 \%$ of patients after 1, 2 and 3 years of treatment, respectively. ${ }^{164}$ These data indicate that lamivudine is safe and effective in children but the benefit must be carefully balanced against the risk of selecting drug resistant mutants.

\section{HBeAg-negative chronic hepatitis B (Table 9)}

Lamivudine has been shown to benefit patients with HBeAg-negative chronic hepatitis B. ${ }^{165-169}$ Several studies have reported that serum HBV DNA is suppressed to undetectable levels by PCR assays in $60 \%$ to $70 \%$ patients after 1 year of treatment. ${ }^{167,168,170,171}$ However, the vast majority $(\approx 90 \%)$ of patients relapsed when treatment was stopped. ${ }^{166}$ Extending the duration of treatment resulted in a progressively lower rate of response due to the selection of lamivudine-resistant mutants. In one study of 201 patients, virologic remission (undetectable HBV DNA by PCR assay) decreased from $73 \%$ at 12 months to $34 \%$ at 48 months while biochemical remission decreased from $84 \%$ to $36 \% .{ }^{172}$

\section{Nonresponders to IFN- $\alpha$ treatment}

A multicenter trial in IFN- $\alpha$ nonresponders found that patients had a similar HBeAg seroconversion rate to lamivudine alone (18\%), a combination of lamivudine and IFN- $\alpha(12 \%)$ or placebo $(13 \%)$ indicating that response of IFN- $\alpha$ nonresponders to lamivudine is similar to treatment-naive patients, and that retreatment with combination of IFN- $\alpha$ and lamivudine did not confer any added benefit compared with retreatment with lamivudine monotherapy. ${ }^{173}$

\section{Bridging Fibrosis and Compensated Cirrhosis}

In a double blind, randomized, placebo-controlled trial of 651 Asian patients who were $\mathrm{HBeAg}$ positive or had HBV DNA $>10^{5} \mathrm{IU} / \mathrm{ml}(>700,000$ genome equivalents $/ \mathrm{ml}$ ), and bridging fibrosis or cirrhosis on liver biopsy a statistically significant difference was observed between those who received lamivudine vs. placebo for overall disease progression (increase in Child-TurcottePugh score, hepatic decompensation or HCC) (7.8\% vs. $17.7 \% P=0.001)$, and for HCC development (3.9\% vs. 7.4\% $P=0.047)$. (77) Clinical benefit was observed mainly among the $51 \%$ patients who did not have breakthrough infection. These data indicate that antiviral therapy can improve clinical outcomes in patients with advanced fibrosis who have maintained viral suppression.

\section{Decompensated cirrhosis}

Studies of lamivudine in patients with decompensated cirrhosis showed that lamivudine treatment is well tolerated and can stabilize or improve liver function in patients with decompensated cirrhosis thereby obviating or delaying the need for liver transplant. ${ }^{174-177}$ However, these studies showed that clinical benefit takes 3-6 months, and that HCC can occur even among patients with clinical improvement. Thus, prompt initiation of treatment and continued HCC surveillance are warranted.

Durability of Response. A follow-up study in nonAsian countries found that 30 of 39 (77\%) patients with $\mathrm{HBeAg}$ seroconversion had durable response after a median follow-up of 37 months (range, 5-46 months) and 8 (20\%) patients had HBsAg seroconversion. ${ }^{178}$ Studies from Asia reported lower rates of durability (50\%-60\%), which may in part be related to a shorter duration of treatment (mean 8-9 months). ${ }^{179,180}$ Several factors have been found to be associated with increased durability of lamivudine-induced $\mathrm{HBeAg}$ seroconversion including longer duration of consolidation treatment - defined as duration of treatment beyond the time after $\mathrm{HBeAg}$ seroconversion, younger age, lower HBV DNA level at the time treatment was stopped, and genotype B vs. C. ${ }^{179-183}$ Although there are no good direct comparison data, it appears that the durability of lamivudine-induced $\mathrm{HBeAg}$ seroconversion is less than that for IFN- $\alpha .{ }^{184}$

Among HBeAg-negative patients, the durability of viral suppression after 1-year of lamivudine treatment is less than $10 \%$. One small study reported that the durability of virologic response was improved to $50 \%$ in patients who had completed 2 years of treatment and had persistently undetectable HBV DNA by PCR assay during year $2 .{ }^{185}$

Lamivudine Resistance. Selection of lamivudine-resistant mutations is the main concern with lamivudine treatment. The most common mutation involves substitution of methionine in the tyrosine-methionine-aspartate-aspartate (YMDD) motif of the HBV DNA polymerase for valine or isoleucine $\mathrm{rtM} 204 \mathrm{~V} / \mathrm{I} .{ }^{186,187}$ This mutation is frequently accompanied by a leucine to methionine substitution in an upstream region (rtL180M). Genotypic resistance can be detected in 14\% to $32 \%$ after 1 year of lamivudine treatment ${ }^{154-156}$ and increases with the duration of treatment to $60 \%$ to $70 \%$ after 5 years of treatment. ${ }^{159,160}$ Factors associated with an increase rate of lamivudine resistance include long duration of treatment, high pretreatment serum HBV DNA level, and a high level of residual virus after initiation of 
treatment. ${ }^{160,188}$ One study reported that the rate of lamivudine resistance was significantly higher in patients whose serum HBV DNA level exceeded $\approx 200 \mathrm{IU} / \mathrm{ml}$ $(1,000$ copies $/ \mathrm{ml})$ after 6 months of treatment compared to those with lower HBV DNA levels (63\% vs. $13 \%) .{ }^{188}$ The clinical course of patients with lamivudine-resistant mutants is variable. In vitro studies showed that rtM204V/I mutation decreases replication fitness of HBV but compensatory mutations selected during continued treatment can restore replication fitness. ${ }^{122,189}$ Virologic breakthrough is usually followed by biochemical breakthrough (increase in ALT after initial normalization), and in some patients may be associated with acute exacerbations of liver disease and rarely hepatic decompensation and death. ${ }^{190-192}$ Exacerbations of hepatitis associated with the emergence of lamivudine resistance had also been reported to be associated with $\mathrm{HBeAg}$ seroconversion, possibly via immune mediated mechanisms. ${ }^{190}$ Hepatitis flares may also occur after withdrawal of treatment due to rapid outgrowth of wild type virus, but two studies in Asia found that the occurrence of hepatitis flares and hepatic decompensation were similar among patients with lamivudine breakthrough who stopped or continued lamivudine treatment. ${ }^{193,194}$

\section{Long-term Outcome of Lamivudine-treated Pa-} tients. Follow-up of patients receiving continued lamivudine treatment showed that the rates of maintained virologic and biochemical response decreased with time due to selection of drug-resistant mutants. ${ }^{160,171,172}$ In patients with maintained viral suppression, necroinflammation is reduced and decrease in fibrosis score as well as regression of cirrhosis was observed. ${ }^{195}$ However, histologic benefit was negated among patients with breakthrough infection. Several studies reported that patients with maintained viral suppression had lower rates of hepatic decompensation as well as liver-related mortality. ${ }^{172,196}$

Dose Regimen. The recommended dose of lamivudine for adults with normal renal function (creatinine clearance $>50 \mathrm{ml} / \mathrm{min}$ ) and no HIV coinfection is 100 $\mathrm{mg}$ orally daily. The recommended dose for children is 3 $\mathrm{mg} / \mathrm{kg} / \mathrm{d}$ with a maximum dose of $100 \mathrm{mg} / \mathrm{d}$. Dose reduction is necessary for patients with renal insufficiency (Table 10a).

The end point of treatment for $\mathrm{HBeAg}$-positive patients is $\mathrm{HBeAg}$ seroconversion. ${ }^{154-156}$ Liver chemistries should be monitored every 3 months and HBV DNA levels every 3-6 months while on therapy, and HBeAg and anti-HBe tested at the end of 1 year of treatment and every 3-6 months thereafter. Treatment may be discontinued in patients who have confirmed $\mathrm{HBeAg}$ seroconversion $(\mathrm{HBeAg}$ loss and anti-HBe detection on 2
Table 10. Adjustment of Adult Dosage of Nucleosid(t)e Analogue in Accordance with Creatinine Clearance

\begin{tabular}{ll}
$\begin{array}{l}\text { Creatinine clearance } \\
\text { (ml/min) }\end{array}$ & \multicolumn{1}{c}{ Recommended dose } \\
\hline $\begin{array}{l}\text { a. Lamivudine } \\
\geq 50\end{array}$ & $100 \mathrm{mg}$ qd \\
$30-49$ & $100 \mathrm{mg}$ first dose, then $50 \mathrm{mg}$ qd \\
$15-29$ & $35 \mathrm{mg}$ first dose, then $25 \mathrm{mg}$ qd \\
$5-14$ & $35 \mathrm{mg}$ first dose, then $15 \mathrm{mg}$ qd \\
$<5$ & $35 \mathrm{mg}$ first dose, then $10 \mathrm{mg}$ qd \\
b. Adefovir & $10 \mathrm{mg}$ daily \\
$\geq 50$ & $10 \mathrm{mg}$ every other day \\
$20-49$ & $10 \mathrm{mg}$ every third day \\
$10-19$ & $10 \mathrm{mg}$ every week following dialysis \\
Hemodialysis patients & NA naïe \\
c. Entecavir & $0.5 \mathrm{mg}$ qd \\
$\geq 50$ & $0.25 \mathrm{mg}$ qd $\quad 0.5 \mathrm{mg}$ qd \\
$30-39$ & $0.15 \mathrm{mg}$ qd $\quad 0.3 \mathrm{mg}$ qd \\
$10-29$ & $0.05 \mathrm{mg}$ qd $\quad 0.1 \mathrm{mg}$ qd \\
$<10$ or hemodialysis* or & \\
continuous ambulatory & \\
peritoneal dialysis &
\end{tabular}

*administer after hemodialysis

occasions 1-3 months apart) and have completed at least 6 months of consolidation therapy after the appearance of anti-HBe. The durability of response after cessation of treatment is expected to be $70 \%$ to $90 \%$. Viral relapse and exacerbations of hepatitis may occur after discontinuation of lamivudine therapy, ${ }^{197}$ including patients who have developed $\mathrm{HBeAg}$ seroconversion, and may be delayed up to 1 year after cessation of treatment. Thus, all patients should be closely monitored after treatment is discontinued (every 1-3 months for the first 6 months, and every 3-6 months thereafter). Reinstitution of lamivudine treatment is usually effective in patients who have not developed resistance. Alternatively, treatment with newer therapies with lower risk of drug resistance may be considered.

Treatment may be continued in patients who have not achieved $\mathrm{HBeAg}$ seroconversion and have no evidence of breakthrough infection as $\mathrm{HBeAg}$ seroconversion may occur with continued treatment. ${ }^{157-159}$ However, the benefits of continued treatment must be balanced against the risks of resistant mutants. With the availability of newer therapies with lower risk of drug resistance, a switch to an alternative treatment may be considered particularly in patients who have received lamivudine for more than 2 years.

In patients who have breakthrough infection, testing for lamivudine-resistant mutants should be performed 
when possible. The vast majority of patients with confirmed lamivudine-resistance should receive rescue therapy with antiviral agents that are effective against lamivudine-resistant HBV mutants. A minority of patients may consider stopping treatment, particularly if they had normal ALT, or if the biopsy showed mild inflammation and no or minimal fibrosis prior to initiation of treatment. ${ }^{193,194}$ Patients whose ALT and HBV DNA levels remain significantly lower than pretreatment values may be maintained on lamivudine temporarily without resorting to rescue therapy but it must be recognized that compensatory mutations will be selected during continued treatment leading to subsequent viral rebound and possibly hepatitis flares.

The end point of treatment for HBeAg-negative chronic hepatitis $B$ is unknown. Post-treatment relapse can occur even in patients with persistently undetectable serum HBV DNA by PCR assay. Because of the need for long durations of treatment, lamivudine is not an optimal first-line treatment for $\mathrm{HBeAg}$-negative chronic hepatitis B.

Predictors of Response. Pretreatment serum ALT is the strongest predictor of response among HBeAg-positive patients. Pooled data from 4 studies with a total of 406 patients who received lamivudine for one year found that $\mathrm{HBeAg}$ seroconversion occurred in $2 \%, 9 \%, 21 \%$, and $47 \%$ of patients with ALT levels within normal, 1-2 times normal, 2-5 times normal, and $>5$ times normal, respectively; the corresponding seroconversion rates for 196 patients in the placebo group were $0 \%, 5 \%, 11 \%$, and $14 \%$, respectively. ${ }^{162}$

Adverse Events. In general, lamivudine is very well tolerated. Various adverse events including a mild (2- to 3 -fold) increase in ALT level have been reported in patients receiving lamivudine, but these events occurred in the same frequency among the controls. ${ }^{154-156}$

\section{Adefovir Dipivoxil (bis-POM PMEA, Hepsera)}

Adefovir dipivoxil is an orally bioavailable pro-drug of adefovir, a nucleotide analog of adenosine monophosphate. It can inhibit both the reverse transcriptase and DNA polymerase activity and is incorporated into HBV DNA causing chain termination. In vitro and clinical studies showed that adefovir is effective in suppressing wild type as well as lamivudine-resistant HBV.

\section{Efficacy in Various Categories of Patients.}

1. HBeAg positive chronic hepatitis B (Table 8) - In a Phase III trial, 515 patients were randomized to receive 10 or $30 \mathrm{mg}$ of adefovir or placebo for 48 weeks. Histologic response was observed in $25 \%$ of those on placebo vs. $53 \%$ and $59 \%$ of patients who received adefovir $10 \mathrm{mg}$ and $30 \mathrm{mg}$, respectively $(P<0.001$, adefovir $10 \mathrm{mg}$ or $30 \mathrm{mg}$ vs. placebo). ${ }^{198}$ The corresponding figures for
HBeAg seroconversion were $12 \%$ and $14 \%$ for adefovir $10 \mathrm{mg}$ and $30 \mathrm{mg}$ groups compared to $6 \%$ for the placebo group $(P=0.049$ and $P=0.011$, respectively). Serum HBV DNA levels decreased by a mean of $0.6,3.5$, and 4.8 $\log _{10}$ copies $/ \mathrm{ml}$, and normalization of ALT levels was observed in $16 \%, 48 \%$, and $55 \%$ of patients who received placebo, adefovir $10 \mathrm{mg}$ and $30 \mathrm{mg}$, respectively $(P<$ 0.001 placebo vs. either dose of adefovir). The side effect profiles in the three groups were similar but $8 \%$ of patients in the adefovir $30 \mathrm{mg}$ dose group had nephrotoxicity (defined as an increase in serum creatinine by $\geq 0.5$ $\mathrm{mg} / \mathrm{dl}$ above the baseline value on two consecutive occasions). These data demonstrated that adefovir for 1-year is beneficial in patients with $\mathrm{HBeAg}$-positive chronic hepatitis and that the 10-mg dose has a more favorable riskbenefit profile. Cumulative $\mathrm{HBeAg}$ seroconversion rates appeared to increase during the second and third years but the exact number of patients who achieved HBeAg seroconversion was unclear.

Some studies have reported that $20 \%-50 \%$ of patients receiving the $10 \mathrm{mg}$ dose of adefovir have primary nonresponse indicating that the approved dose of adefovir may be suboptimal. ${ }^{123}$

2. HBeAg negative chronic hepatitis (Table 9) - In a Phase III trial, 184 patients were randomized in a 2:1 ratio to receive adefovir $10 \mathrm{mg}$ or placebo. At week 48, the treated group had significantly higher rates of response than the placebo group as follows: histologic response, $64 \%$ versus $33 \%(P<0.001)$; normalization of ALT, $72 \%$ versus $29 \%(P<0.001)$; and undetectable serum HBV DNA by PCR assay, 51\% versus $0 \%(P<$ 0.001). ${ }^{199}$ During year 2 , patients who received adefovir in year 1 were randomized to continue adefovir $10 \mathrm{mg}$ or to receive placebo. ${ }^{200}$ At week 96 , the proportion of patients with undetectable serum HBV DNA increased to $71 \%$ in the group that continued to receive adefovir, and decreased to $8 \%$ in the group that stopped therapy. Preliminary data from 55 patients who completed 4 years and 70 patients who completed 5 years of continued adefovir treatment, showed that serum HBV DNA was undetectable in $65 \%$ and $67 \%$ and ALT normalized in $70 \%$ and $69 \%$ respectively of the 4 - and 5- year cohorts. ${ }^{201}$

3. Children - Clinical trials of adefovir in children are ongoing.

4. Decompensated cirrhosis - Adefovir has not been evaluated as a primary treatment for patients with decompensated cirrhosis.

5. Lamivudine-resistant hepatitis B -

a. Decompensated cirrhosis and liver transplant recipients - In a compassionate use study involving 128 patients with decompensated cirrhosis and 196 patients with recurrent hepatitis $B$ after liver transplant, addi- 
tion of adefovir was associated with a $3-4 \log _{10}$ reduction in serum HBV DNA levels, which was sustained throughout the course of treatment. ${ }^{202}$ Among the patients who completed 48 weeks of treatment, $81 \%$ of the pre- and $34 \%$ of the post-transplant patients had undetectable HBV DNA by PCR assay, and $76 \%$ and $49 \%$, respectively had normalization of ALT. ChildTurcotte-Pugh score improved in more than $90 \%$ of the pre-transplant patients, and 1-year survival was $84 \%$ for the pre- and $93 \%$ for the post-transplant patients. Follow-up data on 226 pre-transplant patients showed that viral suppression was maintained in $65 \%$ of patients after 96 weeks of treatment with accompanying improvement in Child-Turcotte-Pugh scores as well as Model for End-stage Liver Disease (MELD) scores. ${ }^{203}$

b. Compensated liver disease - While a pilot study in patients with compensated chronic hepatitis B and lamivudine resistance found no differences in HBV DNA suppression and ALT normalization in persons treated with the combination of lamivudine and adefovir compared to those receiving adefovir alone, ${ }^{204}$ patients who discontinued lamivudine were more likely to develop ALT flares during the first 12 weeks of adefovir monotherapy. In addition, recent data showed that switching to adefovir in patients with lamivudine-resistant $\mathrm{HBV}$ was associated with a higher risk of adefovir-resistance compared to adding adefovir. ${ }^{123,204}$

c. HIV and HBV coinfection - Adefovir when added to existing HIV treatment regimens which included lamivudine $150 \mathrm{mg}$ bid has also been shown to be effective in decreasing serum HBV DNA levels in patients with HIV and HBV coinfection and lamivudine-resistant HBV. ${ }^{205}$

Durability of Response and Long-term Outcome of Adefovir-treated Patients. The durability of $\mathrm{HBeAg}$ seroconversion was examined in 76 patients who had received a median of 80 (range 30-193) weeks of adefovir treatment, and had been followed for a median of 52 (range 5-125) weeks off treatment. HBeAg seroconversion was maintained in 69 (92\%) patients. The seemingly high rate of durability of adefovir-related HBeAg seroconversion may be related to a long duration of treatment (median 80 weeks) and more importantly, a long duration of treatment after HBeAg seroconversion (median 41 weeks). ${ }^{206}$

Among $\mathrm{HBeAg-negative} \mathrm{patients,} \mathrm{viral} \mathrm{suppression}$ was sustained in only $8 \%$ of patients who stopped adefovir after 1-year of treatment. ${ }^{200}$ The vast majority of patients who continued treatment up to 5 years maintained their response but there was minimal incremental response after the first year. HBsAg loss was observed in 5\% of patients after $4-5$ years of continued treatment. ${ }^{201}$ In addition, long-term treatment was associated with a decrease in fibrosis score. Nonetheless, $2 \%$ of patients developed HCC indicating that long-term antiviral treatment does not completely prevent HCC.

Adefovir Resistance. Resistance occurs at a slower rate during adefovir treatment compared to lamivudine and no adefovir-resistant mutations were found after 1 year of treatment in the patients who participated in the Phase III trials. ${ }^{207}$ However, novel mutations conferring resistance to adefovir (asparagine to threonine substitution N236T and alanine to valine or threonine substitution A181V/T) have been described. ${ }^{208,209}$ Aggregate data from 5 studies including 3 studies using the combination of lamivudine and adefovir in patients with lamivudineresistant HBV estimated the cumulative rate of adefovirresistance to be $15 \%$ by 192 weeks. ${ }^{210}$ The phase III trial in $\mathrm{HBeAg}$-negative patients found that the cumulative probabilities of genotypic resistance to adefovir at 1, 2, 3, 4 , and 5 years were $0,3 \%, 11 \%, 18 \%$, and $29 \%$, respectively. ${ }^{201}$ Recent studies using more sensitive methods have reported detection of adefovir-resistant mutations after 1 year of treatment and rates of genotypic resistance exceeding $20 \%$ after 2 years of treatment. ${ }^{123,211}$ In these studies, adefovir resistance was predominantly found in patients with prior lamivudine resistance switched to adefovir monotherapy.

In vitro studies showed that adefovir-resistant mutations decrease susceptibility by 3-15 -fold only. ${ }^{208,209}$ Nevertheless, clinical studies found that viral rebound, hepatitis flares and even hepatic decompensation can occur. $^{212}$ Risk factors for adefovir resistance that have been identified include suboptimal viral suppression and sequential monotherapy. ${ }^{123,211}$ Sequential treatment with lamivudine followed by adefovir had also been reported to select for dual-resistant HBV mutants. ${ }^{212}$

In vitro and clinical studies showed that adefovir-resistant HBV mutants are susceptible to lamivudine and entecavir. ${ }^{209}$ However, in patients with prior lamivudine resistance, who developed adefovir resistance after being switched to adefovir monotherapy, re-emergence of lamivudine-resistant mutations has been reported soon after reintroduction of lamivudine. ${ }^{212}$ There are anecdotal cases where switching from adefovir to tenofovir resulted in a decrease in serum HBV DNA levels. This may be related to a higher dose of tenofovir being used $300 \mathrm{mg}$ vs. adefovir $10 \mathrm{mg}$. One case series reported that two patients with adefovir-resistant HBV responded to entecavir with a decrease in serum HBV DNA to undetectable levels. ${ }^{123}$

Dose Regimen. The recommended dose of adefovir for adults with normal renal function (creatinine clear- 
ance $>50 \mathrm{ml} / \mathrm{min}$ ) is $10 \mathrm{mg}$ orally daily. The dosing interval should be increased in patients with renal insufficiency (Table 10b). Adefovir has not been approved for use in children. Adefovir at the $10 \mathrm{mg}$ dose is ineffective in suppressing HIV replication.

For patients with $\mathrm{HBeAg}$-positive chronic hepatitis B, treatment may be discontinued for those who have confirmed HBeAg seroconversion and have completed an additional 6 months of consolidation treatment. Treatment may be continued in patients who have not achieved $\mathrm{HBeAg}$ seroconversion but in whom HBV DNA levels remain suppressed.

For patients with $\mathrm{HBeAg}$-negative chronic hepatitis B, continued treatment (beyond 1 year) is needed to maintain the response. ${ }^{200}$

For most patients with lamivudine-resistant mutants, particularly those with decompensated cirrhosis or recurrent hepatitis B post-transplant, long-term treatment will be required. Increasing data indicate that lamivudine should be continued indefinitely after the addition of adefovir to reduce the risk of adefovir resistance.

Approximately $30 \%$ of patients who have no prior treatment with NAs have primary nonresponse to adefovir, defined as a $<2 \log$ drop in HBV DNA after 6 months of treatment. ${ }^{213}$ Alternative treatments should be considered for these patients.

Predictors of Response. Retrospective analyses of data from two phase III clinical trials showed that reduction in serum HBV DNA was comparable across the 4 major $\mathrm{HBV}$ genotypes $\mathrm{A}-\mathrm{D}$ in the groups receiving adefovir. ${ }^{214}$ Limited data suggest that $\mathrm{HBeAg}$-positive patients with high pretreatment ALT were more likely to undergo $\mathrm{HBeAg}$ seroconversion.

Adverse Events. Adefovir in $10 \mathrm{mg}$ doses is well tolerated and has a similar side effect profile as placebo in Phase III clinical trials. Nephrotoxicity has been reported in 3\% of patients with compensated liver disease after 4-5 years of continued adefovir therapy, and in $12 \%$ of transplant recipients and $28 \%$ of patients with decompensated cirrhosis during the first year of therapy. ${ }^{201,202}$ Whether the higher rate of nephrotoxicity in the latter two groups of patients is related to concomitant use of nephrotoxic medications, progression of decompensated cirrhosis (hepatorenal syndrome) or a direct effect of adefovir is unclear. Regardless, monitoring of serum creatinine every 3 months is necessary for patients with medical conditions that predispose to renal insufficiency and in all patients on adefovir for more than 1 year. More frequent monitoring should be performed in patients with pre-existing renal insufficiency.

\section{Entecavir (Baraclude)}

Entecavir, a carbocyclic analogue of 2'-deoxyguanosine, inhibits HBV replication at three different steps: the priming of HBV DNA polymerase, the reverse transcription of the negative strand HBV DNA from the pregenomic RNA, and the synthesis of the positive strand HBV DNA. In vitro studies showed that entecavir is more potent than lamivudine and adefovir and is effective against lamivudine-resistant $\mathrm{HBV}$ mutants although the activity is lower compared to wild-type HBV. ${ }^{215}$

\section{Efficacy in Various Categories of Patients.}

1. HBeAg-positive patients (Table 8) - In a phase III clinical trial, 715 patients with compensated liver disease were randomized to receive entecavir $0.5 \mathrm{mg}$ or lamivudine $100 \mathrm{mg}$ daily. At week 48, entecavir resulted in significantly higher rates of histologic $(72 \%$ vs. $62 \%)$, virologic [HBV DNA undetectable by $\mathrm{PCR}$ ] (67\% vs. $36 \%)$ and biochemical (68\% vs. 60\%) responses compared to lamivudine. However, $\mathrm{HBeAg}$ seroconversion rates were similar in the two groups: $21 \%$ vs. $18 \% .^{216}$ Among the patients who had suppressed HBV DNA but remained $\mathrm{HBeAg}$ positive, continuation of treatment in the second year resulted in $\mathrm{HBeAg}$ seroconversion in 11\% of patients in the entecavir group and in $13 \%$ of the lamivudine group. Serum HBV DNA was undetectable by PCR in $81 \%$ vs. $39 \%$, and normalization of ALT occurred in $79 \%$ vs. $68 \%$ of patients who continued entecavir and lamivudine treatment, respectively. ${ }^{217}$

2. HBeAg-negative patients (Table 9) - In a phase III clinical trial 648 patients with compensated liver disease were randomized to receive entecavir $0.5 \mathrm{mg}$ or lamivudine $100 \mathrm{mg}$ daily. At week 48, entecavir resulted in significantly higher rates of histologic (70\% vs. $61 \%)$, virologic (90\% vs. $72 \%)$ and biochemical (78\% vs. $71 \%)$ responses compared to lamivudine. ${ }^{218}$

3. Decompensated cirrhosis / recurrent hepatitis B after liver transplantation - Studies on the safety and efficacy of entecavir in patients with decompensated cirrhosis are ongoing.

4. Lamivudine-refractory HBV - In a dose-finding phase II trial, entecavir was shown to be effective in suppressing lamivudine-resistant HBV but a higher dose 1.0 mg was required. ${ }^{219}$ In a subsequent study, $286 \mathrm{HBeAg-}$ positive patients with persistent viremia while on lamivudine were randomized to receive entecavir $1.0 \mathrm{mg}$ or lamivudine $100 \mathrm{mg}$ daily. At week 48, entecavir resulted in significantly higher rates of histologic (55\% vs. $28 \%)$, virologic ( $21 \%$ vs. $1 \%)$ and biochemical ( $75 \%$ vs. $23 \%)$ responses compared to lamivudine. 220

5. Adefovir-resistant HBV - In vitro studies showed that entecavir is effective in suppressing adefovir-resistant HBV mutants. ${ }^{209}$ There is one case report on the efficacy 
of entecavir in patients with adefovir-resistant HBV. ${ }^{123}$

Durability of Response. Among $\mathrm{HBeAg}$-positive patients who underwent $\mathrm{HBeAg}$ seroconversion during the first year and who stopped treatment at week 48, approximately $70 \%$ of patients remained $\mathrm{HBeAg}$ negative. ${ }^{216,217}$ Consolidation therapy was not included in the phase III trial. Data on the durability of response among $\mathrm{HBeAg}$ negative patients are lacking but it is likely that the vast majority of patients will relapse if treatment is stopped after 1 year.

Entecavir Resistance. Virologic breakthrough was rare in nucleoside-naïve patients, and was observed in only 3\% of patients by Week 96 of entecavir treatment in the two phase III clinical trials. Resistant mutations to lamivudine and entecavir were detected in only two $(<1 \%)$ patients while resistant mutations to lamivudine only were found in three patients. ${ }^{221}$ However, virologic breakthrough was detected in $7 \%$ of patients after 48 weeks and in $16 \%$ after 96 weeks of treatment in the phase III trial of lamivudine refractory patients. ${ }^{220,221}$ Resistance to entecavir appears to occur through a two-hit mechanism with initial selection of M204V/I mutation followed by amino acid substitutions at rtI169, rtT184, rtS202, or rtM250.222 In vitro studies showed that the mutations at positions 169, 184, 202 or 250 on their own have minimal effect on susceptibility to entecavir, but susceptibility to entecavir is decreased by 10-250-fold when one of these mutations is present with lamivudineresistant mutations, and by $>500$-fold when two or more entecavir-resistant mutations are present with lamivudine-resistant mutations. Lamivudine should be discontinued when patients are switched to entecavir to decrease the risk of entecavir resistance. In vitro studies showed that entecavir-resistant mutations are susceptible to adefovir, but there are very little clinical data on the efficacy of adefovir in patients with entecavir-resistant HBV.

Dose Regimen. The approved dose of entecavir for nucleoside-naïve patients is $0.5 \mathrm{mg}$ daily p.o. and for lamivudine-refractory/resistant patients is $1.0 \mathrm{mg}$ daily p.o. Doses should be adjusted for patients with estimated creatinine clearance $<50 \mathrm{ml} / \mathrm{min}$ (Table 10c).

Predictors of Response. Entecavir appears to be equally effective in decreasing serum HBV DNA levels and in inducing histologic improvement in Asians and Caucasians, and across HBV genotypes A-D and a wide range of pretreatment HBV DNA and ALT levels. However, $\mathrm{HBeAg}$ seroconversion rates were lower in patients with normal ALT, being 12\%, 23\%, and 39\% among those with pretreatment ALT $<2,2-5$, and $>5$ times normal, respectively. 223

Adverse Events. Entecavir had a similar safety profile as lamivudine in clinical trials. ${ }^{216,218}$ Studies in rodents exposed to doses 3-40 times that in humans found an increased incidence of lung adenomas, brain gliomas and HCCs. ${ }^{224}$ To date, no difference in the incidence of HCC or other neoplasm has been observed between patients who received entecavir versus lamivudine.

\section{L-deoxythymidine (Telbivudine/LdT, Tyzeka)}

Telbivudine is an L-nucleoside analogue with potent antiviral activity against HBV. Clinical trials showed that telbivudine is more potent than lamivudine in suppressing HBV replication. ${ }^{225-228}$ However, telbivudine is associated with a high rate of resistance and telbivudineresistant mutations are cross-resistant with lamivudine. Therefore, telbivudine monotherapy has a limited role in the treatment of hepatitis B.

\section{Efficacy in Various Categories of Patients.}

1. HBeAg-positive patients (Table 8) - A Phase III clinical trial involving 921 patients showed that a significantly higher percent of patients who received telbivudine had undetectable HBV DNA by PCR assay compared to those who received lamivudine: $60 \%$ vs. $40 \%$ and $54 \%$ vs. $38 \%$, after 1 and 2 years of treatment, respectively. ${ }^{227,228}$ Telbivudine also resulted in a higher percent of patients with normalization of ALT than lamivudine: $77 \%$ vs. $75 \%(\mathrm{NS})$ and $67 \%$ vs. $61 \%(P<0.05)$ after 1 and 2 years of treatment, respectively. However, there was no difference in the rate of $\mathrm{HBeAg}$ loss at the end of 1 and 2 years of treatment: $26 \%$ vs. $23 \%$, and $34 \%$ vs. $29 \%$ of patients who received telbivudine and lamivudine, respectively.

2. HBeAg-negative patients (Table 9) - The Phase III clinical trial which included $446 \mathrm{HBeAg}$-negative patients showed that a significantly higher percent of patients who received telbivudine had undetectable HBV DNA by PCR assay compared to those who received lamivudine: $88 \%$ vs. $71 \%$ and $79 \%$ vs. $53 \%$, after 1 and 2 years of treatment, respectively. ${ }^{227,228}$ Normalization of ALT was observed in: $74 \%$ vs. $79 \%$ (NS) and $75 \%$ vs. $67 \%(P<0.05)$ after 1 and 2 years of telbivudine and lamivudine treatment, respectively.

Telbivudine Resistance. Telbivudine selects for mutations in the YMDD motif. To date, only M204I (but not M204V) has been observed. ${ }^{225}$ Although telbivudine is associated with a lower rate of drug resistance than lamivudine, the resistance rate is substantial and increases exponentially after the first year of treatment. In the phase III clinical trial, genotypic resistance after 1 and 2 years of treatment was observed in $4.4 \%$ and $21.6 \%$ of $\mathrm{HBeAg}$ positive and in $2.7 \%$ and $8.6 \%$ of $\mathrm{HBeAg}$-negative patients who received telbivudine compared to $9.1 \%$ and $35 \%$ of $\mathrm{HBeAg}$-positive and $9.8 \%$ and $21.9 \%$ of $\mathrm{HBeAg}$ negative patients who received lamivudine. The lower re- 
sistance rate in the lamivudine group compared to previously reported clinical trials on lamivudine ${ }^{160}$ may be related to the fact that only patients with virologic breakthrough were tested and a less sensitive method (direct sequencing) was used for detection of resistant mutations.

Dose Regimen. The approved dose of telbivudine is $600 \mathrm{mg}$ daily. Doses should be adjusted for patients with estimated creatinine clearance $<50 \mathrm{ml} / \mathrm{min}$ (Table 10d).

Predictors of Response. Preliminary data suggest that week 24 virologic response was the most important predictor of virologic and biochemical responses as well as resistance at week 96.229 However, even among patients with undetectable HBV DNA by PCR at week 24, telbivudine resistance was observed in $4 \%$ of patients by week 96 .

Adverse Events. Telbivudine is well tolerated and has a safety profile comparable to lamivudine. ${ }^{225}$

\section{Other Therapies}

\section{Emtricitabine (Emtriva, FTC)}

Emtricitabine is a potent inhibitor of HIV and HBV replication. FTC has been approved for HIV treatment as Emtriva (FTC only) and as Truvada (in combination with tenofovir as a single pill). Because of its structural similarity with lamivudine (3TC), treatment with FTC selects for the same resistant mutants.

In one study of 248 patients (63\% were $\mathrm{HBeAg}$ positive) FTC $200 \mathrm{mg}$ daily resulted in a significantly higher rate of histologic (62\% vs. $25 \%)$, virologic [undetectable HBV DNA by PCR assay] (54\% vs. $2 \%$ ) and biochemical (65\% vs. $25 \%$ ) responses at week 48 compared to placebo but $\mathrm{HBeAg}$ seroconversion rates were identical - $12 \%$ in the two groups. ${ }^{230}$ FTC-resistant mutations in the YMDD motif were detected in $13 \%$ of patients.

\section{Tenofovir (Viread)}

Tenofovir disoproxil fumarate is a nucleotide analogue that has been approved for the treatment of HIV infection as Viread (tenofovir only) or Truvada (tenofovir plus emtricitabine as a single pill). Tenofovir is structurally similar to adefovir. In vitro studies showed that tenofovir and adefovir are equipotent. Because tenofovir appears to be less nephrotoxic, the approved dose is much higher than that of adefovir, $300 \mathrm{mg}$ versus $10 \mathrm{mg}$ daily. This may explain why tenofovir has more potent antiviral activity in clinical studies.

Retrospective analysis of trials in patients with HIV infection that included subsets of patients coinfected with HBV demonstrated that tenofovir was associated with a significant reduction in HBV DNA levels. Several studies, including one prospective randomized study of $52 \mathrm{pa}-$ tients with HIV and HBV coinfection, found that teno- fovir led to a greater reduction in serum HBV DNA levels than adefovir. ${ }^{231-235}$ Similar results have been obtained in HIV-negative patients with lamivudine-resistant HBV. ${ }^{235,236}$ There have also been case reports of viral rebound when patients with virologic response were switched from tenofovir to adefovir and further viral reduction when patients with inadequate viral suppression were switched from adefovir to tenofovir. ${ }^{237}$ Tenofovir is generally well tolerated but it has been rarely reported to cause Fanconi syndrome and renal insufficiency. ${ }^{238}$

\section{Clevudine (LFMAU, 2'-fuoro-5-methyl-beta-L- arabinofuranosyl uracil)}

Clevudine is a pyrimidine nucleoside analogue that is effective in inhibiting HBV replication in in vitro and in animal models. Clinical trials showed that clevudine in doses of $30 \mathrm{mg}$ daily for up to 24 weeks was well tolerated. Serum HBV DNA levels were undetectable by PCR assay at the end of treatment in $59 \%$ of $\mathrm{HBeAg}$-positive and in 92\% of $\mathrm{HBeAg}$-negative patients. ${ }^{239,240} \mathrm{~A}$ unique feature of clevudine is the durability of viral suppression, persisting for up to 24 weeks after withdrawal of treatment in some patients. ${ }^{226}$ Nonetheless, clevudine has not been shown to increase the rate of $\mathrm{HBeAg}$ seroconversion compared to placebo controls and in vitro studies suggest that it can select for mutations in the YMDD motif.

\section{Thymosin}

Thymic-derived peptides can stimulate T-cell function. Clinical trials have shown that thymosin is well tolerated but data on efficacy are conflicting. ${ }^{241-245}$

\section{Combination Therapies}

Combination therapies have been proven to be more effective than monotherapy in the treatment of HIV and HCV infections. The potential advantages of combination therapies are additive or synergistic antiviral effects, and diminished or delayed resistance. The potential disadvantages of combination therapies are added costs, increased toxicity, and drug interactions. Various combination therapies have been evaluated; to date, none of the combination therapies has been proven to be superior to monotherapy in inducing a higher rate of sustained response. Although several combination therapies have been shown to reduce the rate of lamivudine resistance compared to lamivudine monotherapy, there are as yet no data to support that combination therapies will reduce the rate of resistance to antiviral compounds that have a low risk of drug resistance when used alone. 
Table 11. Comparison of Approved Treatments of Chronic Hepatitis B

\begin{tabular}{|c|c|c|c|c|c|}
\hline & IFN $\alpha$ & Lamivudine & Adefovir & Entecavir & Telbivudine \\
\hline \multicolumn{6}{|l|}{ Indications } \\
\hline HBeAg+, normal ALT & Not indicated & Not indicated & Not indicated & Not indicated & Not indicated \\
\hline $\mathrm{HBeAg}+$ chronic hepatitis & Indicated & Indicated $^{\dagger}$ & Indicated & Indicated & Indicated ${ }^{\dagger}$ \\
\hline HBeAg- chronic hepatitis & Indicated & Indicated $^{\dagger}$ & Indicated & Indicated & Indicated ${ }^{\dagger}$ \\
\hline \multicolumn{6}{|l|}{ Duration of treatment } \\
\hline HBeAg+ chronic hepatitis & 4-12 months\# & $\geq 1$ year** & $\geq 1$ year** & $\geq 1$ year** & $\geq 1$ year** \\
\hline HBeAg - chronic hepatitis & 1 year & $>1$ year & $>1$ year & $>1$ year & $>1$ year \\
\hline Route & Subcutaneous & Oral & Oral & Oral & Oral \\
\hline Side effects & Many & Negligible & Potential Nephrotoxicity & Negligible & Negligible \\
\hline Drug resistance & - & $\begin{array}{l}\sim 20 \% \text {, year } 1 \\
\sim 70 \% \text {, year } 5\end{array}$ & $\begin{array}{l}\text { None, year } 1 \\
29 \% \text {, year } 5\end{array}$ & $<1 \%$ up to year $2^{\wedge}$ & $\sim 25 \%$ up to year 2 \\
\hline Cost* & High & Low & Intermediate & High & Intermediate \\
\hline
\end{tabular}

*Based on treatment duration of 1 year

\#PegIFN approved for 12 months

**Treatment for at least 12 months continuing for at least 6 months after anti-HBe seroconversion

${ }^{\wedge}$ Entecavir resistance reported within year 1 in patients with prior lamivudine resistance

${ }^{\dagger}$ Not preferred drug due to high rate of resistance

\section{Standard or PegIFN- $\alpha$ and Lamivudine}

Treatment naïve patients. Five large trials (1 using standard IFN- $\alpha$ and 4 using pegIFN- $\alpha, 4$ in $\mathrm{HBeAg}$ positive patients and 1 in $\mathrm{HBeAg}$-negative patients) have been conducted comparing the combination of IFN- $\alpha$ and lamivudine to lamivudine alone and/or IFN- $\alpha$ alone. ${ }^{51,52,152,153,156}$ All studies found that combination therapy had greater on-treatment viral suppression and higher rates of sustained off-treatment response compared to lamivudine alone, but no difference in sustained offtreatment virologic response compared to IFN- $\alpha$ alone. Although combination therapy was associated with lower rates of lamivudine resistance compared to lamivudine monotherapy, a low rate of lamivudine resistance was encountered compared to none in patients who received IFN- $\alpha$ alone.

\section{IFN- $\alpha$ Non-responders}

Combination therapy of standard IFN- $\alpha$ and lamivudine is not more effective than lamivudine alone in the retreatment of IFN- $\alpha$ non-responders. ${ }^{173}$

\section{Lamivudine and Adefovir}

Nucleoside-Naïve Patients. One trial included 115 patients randomized to receive the combination of lamivudine and adefovir or lamivudine alone. At week 52, there was no difference in HBV DNA suppression, ALT normalization or $\mathrm{HBeAg}$ loss. ${ }^{246}$ Results at week 104 were also comparable in the two groups. Serum HBV DNA was undetectable in $14 \%$ versus $26 \%$, ALT normalization in $41 \%$ versus $47 \%$, and $\mathrm{HBeAg}$ seroconversion in $20 \%$ versus $13 \%$, in the groups that received combination therapy and lamivudine monotherapy, respectively. ${ }^{247} \mathrm{Al}-$ though genotypic resistance was less common in the combination group, a substantial percent had mutation in the YMDD motif $(15 \%$ versus $43 \%$ in the lamivudine monotherapy group). These data indicate that the combination of lamivudine and adefovir as de novo therapy does not have additive or synergistic antiviral effects and resistance to lamivudine is not completely prevented

Patients with Lamivudine-resistant HBV. One small trial in patients with compensated liver disease showed that the combination of adefovir and lamivudine was not superior to adefovir alone in decreasing serum HBV DNA levels. ${ }^{248}$ However, hepatitis flares were less frequent during the transition period in the combination therapy group. Furthermore, recent data suggest that continuation of lamivudine reduces the rate of resistance to adefovir ${ }^{123,204}$. Thus, increasing evidence support that adding adefovir is better than switching to adefovir monotherapy for patients with lamivudine-resistant $\mathrm{HBV}$.

\section{Lamivudine and Telbivudine}

One trial conducted in nucleoside-naïve $\mathrm{HBeAg}$-positive patients demonstrated that the combination of lamivudine and telbivudine was inferior for all parameters of response compared to telbivudine alone. ${ }^{225}$

Recommendations for the Treatment of Chronic Hepatitis B: Who to treat and what treatment to use (Tables 11 and 12): Current therapy of chronic hepatitis $B$ does not eradicate HBV and has limited long-term efficacy. Thus, careful consideration of the patient's age, severity of liver disease, likelihood of response, and potential adverse events is needed before treatment is initiated. Treatment is indicated if the risk of liver-related morbidity and mortality in the near future (5-10 years) and the likelihood of achieving maintained viral suppres- 
Table 12. Recommendations for Treatment of Chronic Hepatitis B

\begin{tabular}{|c|c|c|c|}
\hline HBeAg & HBV DNA (PCR) & ALT & Treatment strategy \\
\hline+ & $>20,000 \mathrm{IU} / \mathrm{ml}$ & $\leq 2 \times$ ULN & $\begin{array}{l}\text { Low efficacy with current treatment. } \\
\text { Observe; consider treatment when ALT becomes elevated. } \\
\text { Consider biopsy in persons }>40 \text { years, ALT persistently high normal-2x ULN, or with family history of HCC. } \\
\text { Consider treatment if HBV DNA }>20,000 \mathrm{IU} / \mathrm{ml} \text { and biopsy shows moderate/severe inflammation or } \\
\quad \text { significant fibrosis }\end{array}$ \\
\hline+ & $>20,000 \mathrm{IU} / \mathrm{ml}$ & $>2 \times U \mathrm{ULN}$ & $\begin{array}{l}\text { Observe for 3-6 months and treat if no spontaneous HBeAg loss } \\
\text { Consider liver biopsy prior to treatment if compensated } \\
\text { Immediate treatment if icteric or clinical decompensation } \\
\text { IFN } \alpha \text { /pegIFN } \alpha \text {, LAM, ADV, ETV or LdT may be used as initial therapy } \\
\text { LAM and LdT not preferred due to high rate of drug resistance } \\
\text { End-point of treatment - Seroconversion from HBeAg to anti-HBe } \\
\text { Duration of therapy } \\
\text { - IFN- } \alpha \text { : } 16 \text { weeks } \\
\text { - PegIFN- } \alpha \text { : } 48 \text { weeks } \\
\text { - LAM/ADV/ETV/LdT: minimum } 1 \text { year, continue for at least } 6 \text { months after HBeAg seroconversion } \\
\text { IFN } \alpha \text { non-responders / contraindications to IFN } \alpha \rightarrow \text { ADV/ETV } \\
\text { IFN- } \alpha / \text { peg IFN- } \alpha \text {, LAM, ADV, ETV or LdT may be used as initial therapy, LAM and LdT not preferred due to }\end{array}$ \\
\hline- & $>20,000 \mathrm{lU} / \mathrm{ml}$ & $>2 \times$ ULN & $\begin{array}{l}\text { high rate of drug resistance } \\
\text { End-point of treatment - not defined } \\
\text { Duration of therapy } \\
- \text { IFN- } \alpha / \text { pegIFN- } \alpha \text { : } 1 \text { year } \\
- \text { LAM/ADV/ETV/LdT: }>1 \text { year } \\
\text { IFN } \alpha \text { non-responders / contraindications to IFN- } \alpha \rightarrow \text { ADV/ETV }\end{array}$ \\
\hline- & $>2,000 \mathrm{IU} / \mathrm{ml}$ & $1->2 \times$ ULN & $\begin{array}{l}\text { Consider liver biopsy and treat if liver biopsy shows moderate/severe necroinflammation or significant } \\
\text { fibrosis }\end{array}$ \\
\hline- & $\leq 2,000 \mathrm{IU} / \mathrm{ml}$ & $\leq \mathrm{ULN}$ & Observe, treat if HBV DNA or ALT becomes higher \\
\hline$+1-$ & detectable & Cirrhosis & $\begin{array}{l}\text { Compensated: } \\
\text { HBV DNA }>2,000 \mathrm{IU} / \mathrm{ml}-\text { Treat, LAM/ADV/ETV/LdT may be used as initial therapy. LAM and LdT not } \\
\text { preferred due to high rate of drug resistance } \\
\text { HBV DNA }<2,000 \mathrm{IU} / \mathrm{ml}-\text { Consider treatment if ALT elevated } \\
\text { Decompensated: Coordinate treatment with transplant center, LAM (or LdT) + ADV or ETV preferred. Refer } \\
\quad \text { for liver transplant }\end{array}$ \\
\hline$+/-$ & undetectable & Cirrhosis & $\begin{array}{l}\text { Compensated: Observe. } \\
\text { Decompensated: Refer for liver transplant }\end{array}$ \\
\hline
\end{tabular}

Abbreviations: ALT, alanine aminotransferase; ULN , upper limit of normal; IFN $\alpha$, interferon alpha; pegIFN- $\alpha$, pegylated IFN-alpha; LAM, lamivudine; ADV, adefovir; ETV, entecavir; LdT, telbivudine.

sion during continued treatment are high. Treatment is also indicated if the risk of liver-related morbidity and mortality in the foreseeable future (10-20 years) and the likelihood of achieving sustained viral suppression after a defined course of treatment are high. Treatment is not indicated if the risk of liver-related morbidity or mortality in the next 20 years and the likelihood of achieving sustained viral suppression after a defined course of treatment are low. Because of the fluctuating nature of chronic HBV infection, the risk of liver-related morbidity and mortality and the likelihood of response may vary as patient progresses through the course of chronic HBV infection. Thus, continued monitoring is essential for risk assessment.

In choosing which antiviral agent to use as the firstline therapy, consideration should be given to the safety and efficacy of the treatment, risks of drug resistance, costs of the treatment (medication, monitoring tests, and clinic visits), as well as patient and provider preferences, and for women - when and whether they plan to start a family. The pros and cons of the approved treatments are summarized in Table 11. Although the efficacy is not substantially different, pegIFN- $\alpha$ is likely to supersede standard IFN- $\alpha$ because of its more convenient dosing schedule. In view of the high rate of drug resistance during long-term treatment, lamivudine and telbivudine are not preferred except where only a short course of treatment is planned. While tenofovir is not yet approved for the treatment of hepatitis $B$, emerging data suggest that its safety profile is similar to that of adefovir and its antiviral efficacy in wildtype as well as lamivudine-resistant HBV is comparable or superior to adefovir. Finally, while combination therapy seems to be a more logical approach, none of the combination regimens tested to date is clearly superior.

Patients receiving IFN- $\alpha$ therapy should have blood counts and liver panel monitored every 4 weeks, thyroid stimulating hormone (TSH) and HBV DNA levels every 12 weeks, and, if initially $\mathrm{HBeAg}$-positive, $\mathrm{HBeAg}$ /anti$\mathrm{HBe}$ every 24 weeks during treatment. Blood counts, liver 
panel, TSH and HBV DNA, and if initially HBeAg positive, $\mathrm{HBeAg} /$ anti-HBe should be tested every 12 weeks during the first 24 weeks post-treatment. Patients receiving NA therapy should have liver panel monitored every 12 weeks and HBV DNA levels every 12-24 weeks, and, if initially $\mathrm{HBeAg}$-positive $\mathrm{HBeAg} / \mathrm{anti}-\mathrm{HBe}$ every 24 weeks during treatment. In addition serum creatinine should be tested every 12 weeks for patients receiving adefovir or tenofovir. HBsAg should be tested every 6-12 months in those who are $\mathrm{HBeAg}$ negative with persistently undetectable serum HBV DNA by PCR assay.

Recommendations on Whom to Treat and with What Antiviral Agent (Table 12)

(15). Patients with HBeAg-positive chronic hepatitis $\mathrm{B}$

a. ALT greater than 2 times normal or moderatel severe hepatitis on biopsy, and HBV DNA >20,000 $I U / m l$. These patients should be considered for treatment. (I)

- Treatment should be delayed for 3 to 6 months in persons with compensated liver disease to determine if spontaneous HBeAg seroconversion occurs. (II-2)

- Patients with icteric ALT flares should be promptly treated. (III)

- Treatment may be initiated with any of the 6 approved antiviral medications, but pegIFN- $\alpha$, adefovir or entecavir are preferred. (I)

b. ALT persistently normal or minimally elevated ( $<2$ times normal). These patients generally should not be initiated on treatment. (I)

- Liver biopsy may be considered in patients with fluctuating or minimally elevated ALT levels especially in those above $\mathbf{4 0}$ years of age. (II-3)

- Treatment may be initiated if there is moderate or severe necroinflammation or significant fibrosis on liver biopsy. (I)

c. Children with elevated ALT greater than 2 times normal. These patients should be considered for treatment if ALT levels remain elevated at this level for longer than 6 months. (I)

- Treatment may be initiated with IFN- $\alpha$ or lamivudine. (I)

16. Patients with $\mathrm{HBeAg}$-negative chronic hepatitis B (serum HBV DNA $>20,000 \mathrm{IU} / \mathrm{ml}$ and elevated ALT > 2 times normal) should be considered for treatment. (I)

- Liver biopsy may be considered for HBeAg-negative patients with lower HBV DNA levels $(2,000$ $20,000 \mathrm{IU} / \mathrm{ml}$ ) and borderline normal or minimally elevated ALT levels. (II-2)

- Treatment may be initiated if there is moderate/ severe inflammation or significant fibrosis on biopsy.
Table 13. Management of Antiviral-Resistant HBV

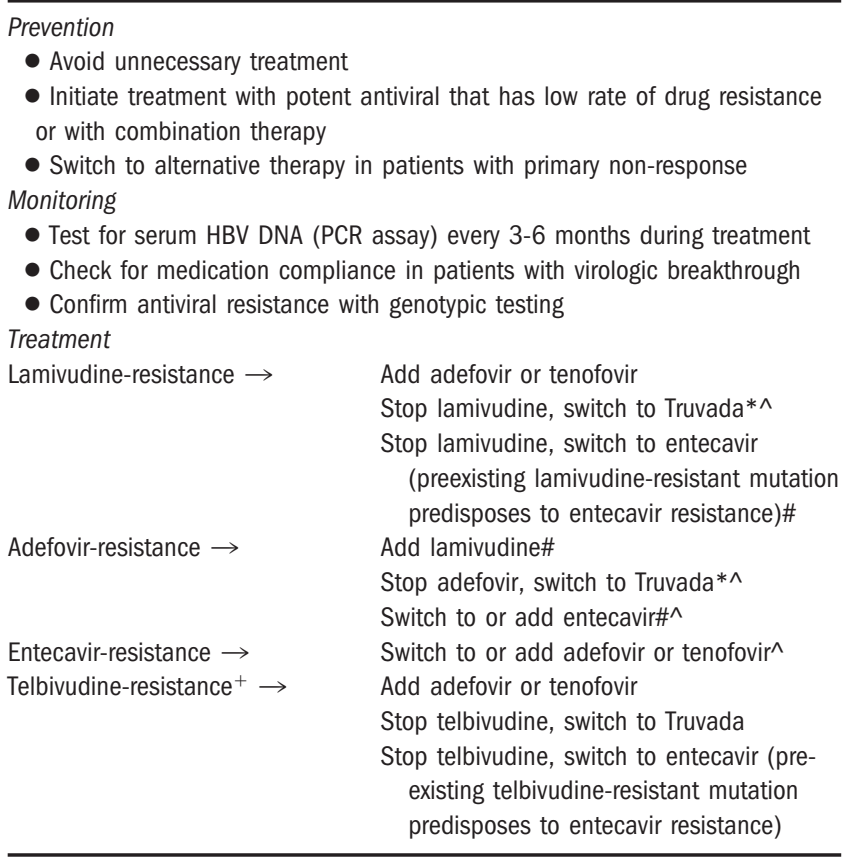

*Truvada $=$ combination pill with emtricitabine $200 \mathrm{mg}$ and tenofovir $300 \mathrm{mg}$ \#Durability of viral suppression unknown, especially in patients with prior lamivudine resistance

^In HIV coinfected persons; scanty in vivo data in non HIV infected persons ${ }^{+}$Clinical data not available

(I)

- Treatment may be initiated with any of the 6 approved antiviral medications but pegIFN- $\alpha$, adefovir or entecavir are preferred in view of the need for long-term treatment. (I for pegIFN- $\alpha$, adefovir, entecavir and telbivudine and II-1 for IFN- $\alpha$ and lamivudine).

17. Patients who failed to respond to prior IFN- $\alpha$ (standard or pegylated) therapy may be retreated with nucleoside analogues (NA) if they fulfill the criteria listed above. (I)

18. Patients who failed to achieve primary response as evidenced by $<2$ log decrease in serum HBV DNA level after at least 6 months of NA therapy should be switched to an alternative treatment. (III)

19. Patients who develop breakthrough infection while receiving NA therapy (Table 13)

- Compliance should be ascertained, and treatment resumed in patients who have had long lapses in medications. (III)

- A confirmatory test for antiviral-resistant mutation should be performed if possible to differentiate primary non-response from breakthrough infection and to determine if there is evidence of multi-drug resistance (in patients who have been exposed to more than one NA treatment). (III) 
- All patients with virologic breakthrough should be considered for rescue therapy. (II-2)

- For patients in whom there was no clear indication for hepatitis $B$ treatment and who continue to have compensated liver disease, withdrawal of therapy may be considered but these patients need to be closely monitored and treatment reinitiated if they experience severe hepatitis flares. (III)

20. Treatment of patients with lamivudine (or telbivudine)-resistant $\mathrm{HBV}$

a. If adefovir is used, lamivudine (or telbivudine) should be continued indefinitely to decrease the risk of hepatitis flares during the transition period and to reduce the risk of subsequent adefovir resistance. (II-3 for lamivudine-resistant $\mathrm{HBV}$ and III for telbivudineresistant $\mathrm{HBV}$ )

b. If entecavir is used, lamivudine or telbivudine should be stopped as continued presence of lamivudine (or telbivudine)-resistant mutations will increase the risk of entecavir resistance. (II-3 for lamivudineresistant $\mathrm{HBV}$ and III for telbivudine-resistant $\mathrm{HBV}$ )

21. Treatment of patients with adefovir-resistant HBV

a. In patients with no prior exposure to other NA, lamivudine or entacavir may be added. (III)

b. In patients with prior lamivudine resistance in whom lamivudine had been stopped when treatment was switched to adefovir, lamivudine may be added but the durability of response is unknown and reemergence of lamivudine-resistant mutations has been reported. (II-2)

22. Treatment of patients with entecavir-resistant HBV

a. Adefovir can be used as it has been shown to have activity against entecavir-resistant $\mathrm{HBV}$ in in vitro studies, but clinical data are lacking. (II-3)

23. Patients with compensated cirrhosis - Treatment should be considered for patients with ALT $>2$ times normal, and for patients with normal or minimally elevated ALT if serum HBV DNA levels are high (>2,000 IU/ml). (II-2)

a. Patients with compensated cirrhosis are best treated with NAs because of the risk of hepatic decompensation associated with IFN- $\alpha$-related flares of hepatitis. In view of the need for long-term therapy, adefovir or entecavir is preferred. (II-3)

24. Patients with decompensated cirrhosis Treatment should be promptly initiated with a NA that can produce rapid viral suppression with low risk of drug resistance. (II-1)

a. Lamivudine or adefovir may be used as initial treatment preferably in combination to reduce the risk of drug resistance and to achieve rapid virus suppression. (II-2) Telbivudine may be substituted for lamivudine but clinical data documenting its safety and efficacy in patients with decompensated cirrhosis are lacking.

b. Entecavir would be an appropriate treatment in this setting but clinical data documenting its safety and efficacy in patients with decompensated cirrhosis are lacking. (III)

c. Treatment should be coordinated with a transplant center. (III)

d. IFN- $\alpha /$ pegIFN $\alpha$ should not be used in patients with decompensated cirrhosis. (II-3)

25. In patients with inactive $\mathrm{HBsAg}$ carrier state antiviral treatment is not indicated, but these patients should be monitored (see Recommendation 12). (II-2)

\section{Dose Regimens}

26. IFN- $\alpha$ and pegIFN- $\alpha$ are administered as subcutaneous injections.

a. The recommended dose of standard IFN- $\alpha$ for adults is 5 MU daily or 10 MU thrice weekly. The recommended dose of pegIFN- $\alpha 2 \mathrm{a}$ is $180 \mathrm{mcg}$ weekly. (I)

b. The recommended IFN- $\alpha$ dose for children is 6 $\mathrm{MU} / \mathrm{m}^{2}$ thrice weekly with a maximum of $10 \mathrm{MU}$. (I) PegIFN- $\alpha$ has not been approved for treatment of chronic hepatitis $B$ in children.

c. The recommended treatment duration for $\mathrm{HBeAg}$-positive chronic hepatitis $\mathrm{B}$ is 16 weeks for standard IFN- $\alpha$ and 48 weeks for pegIFN- $\alpha$. (I)

d. The recommended treatment duration for HBeAg-negative chronic hepatitis $B$ is $\mathbf{4 8}$ weeks for both standard and peg-IFN- $\alpha$ (II-3)

27. Lamivudine is administered orally.

a. The recommended lamivudine dose for adults with normal renal function and no HIV coinfection is $100 \mathrm{mg}$ daily (I). Dose adjustment is needed for patients with estimated glomerular filtration rate $<50$ $\mathrm{ml} / \mathrm{min}$ (Table 10a). (I)

b. The recommended lamivudine dose for children is $3 \mathrm{mg} / \mathrm{kg} / \mathrm{d}$ with a maximum of $100 \mathrm{mg} / \mathrm{d}$. (I)

c. The recommended dose of lamivudine for persons co-infected with HIV is $150 \mathrm{mg}$ twice daily. Lamivudine should only be used in combination with other antiretroviral medications. (I)

28. Adefovir is administered orally.

a. The recommended adefovir dose for adults with normal renal function is $10 \mathrm{mg}$ daily. (I) Dose adjustment is needed for patients with estimated glomerular filtration rate $<50 \mathrm{ml} / \mathrm{min}$ (Table $10 \mathrm{~b}$ ).

29. Entecavir is administered orally. 
a. The recommended entecavir dose for adults with normal renal function is $0.5 \mathrm{mg}$ daily for patients with no prior lamivudine treatment, and $1.0 \mathrm{mg}$ daily for patients who are refractory/resistant to lamivudine. (I) Dose adjustment is needed for patients with estimated glomerular filtration rate $<50 \mathrm{ml} / \mathrm{min}$ (Table 10c).

30. Telbivudine is administered orally.

a. The recommended dose for adults with normal renal function is $600 \mathrm{mg}$ daily. (I) Dose adjustment is needed for patients with estimated glomerular filtration rate $<50 \mathrm{ml} / \mathrm{min}$ (Table $10 \mathrm{~d}$ ).

31. Duration of nucleoside analogue treatment

a. HBeAg-positive chronic hepatitis B - Treatment should be continued until the patient has achieved $\mathrm{HBeAg}$ seroconversion and completed at least 6 months of additional treatment after appearance of anti-HBe. (I)

- Close monitoring for relapse is needed after withdrawal of treatment. (I)

b. HBeAg-negative chronic hepatitis $B-$ Treatment should be continued until the patient has achieved HBsAg clearance. (I)

c. Compensated cirrbosis - These patients should receive long-term treatment. However, treatment may be stopped in $\mathrm{HBeAg}$-positive patients if they have confirmed HBeAg seroconversion and have completed at least 6 months of consolidation therapy and in HBeAg-negative patients if they have confirmed HBsAg clearance. (II-3)

- Close monitoring for viral relapse and hepatitis flare is mandatory if treatment is stopped. (II-3)

d. Decompensated cirrhosis and recurrent hepatitis $B$ post-liver transplantation - Life-long treatment is recommended. (II-3)

\section{Special Populations}

\section{Coinfection with $H B V$ and $H C V$}

There is scanty information on the treatment of HBV/ $\mathrm{HCV}$ coinfection and recommendations on treatment for $\mathrm{HBV} / \mathrm{HCV}$ coinfection cannot be made at this time. ${ }^{249-251}$ Two studies on standard IFN- $\alpha$ and ribavirin showed no difference in sustained virologic response to $\mathrm{HCV}$ infection in patients with $\mathrm{HBV} / \mathrm{HCV}$ co-infection compared to patients with HCV infection only. However, rebound in serum HBV DNA levels after an initial decline, and reactivation of HBV replication in patients who had undetectable HBV DNA prior to treatment have been reported.

\section{Coinfection with $H B V$ and $H D V$}

The primary endpoint of treatment is the suppression of HDV replication, which is usually accompanied by normalization of ALT level and decrease in necroinflammatory activity on liver biopsy. The only approved treatment of chronic hepatitis D is IFN- $\alpha$. One study found that high dose (9 MU 3 times a week) IFN- $\alpha$ had higher rates of virologic and biochemical as well as histologic response than those who received IFN- $\alpha 3$ MU 3 times a week or placebo. ${ }^{252}$ Although most patients had viral relapse, improvement in liver histology was maintained 10 years post-treatment among the patients who received high-dose IFN- $\alpha .{ }^{253}$ Two recent trials support the use of pegIFN- $\alpha$ in chronic hepatitis $\mathrm{D}$, one study showed that addition of ribavirin did not improve the response. ${ }^{254,255}$

Lamivudine has been evaluated in a small number of patients and found to be ineffective in inhibiting HDV replication. $2^{56}$

Based on available data, high-dose IFN- $\alpha$ (9 MU 3 times a week) or pegIFN- $\alpha$ for 1 year appears to have long-term beneficial effects in patients with chronic hepatitis D.

\section{Co-Infection with $H B V$ and $H I V$}

Clinical studies in patients with HBV/HIV coinfection reported lower response rates to standard IFN- $\alpha$ treatment than those with HBV monoinfection. ${ }^{257}$ Responders tend to have a higher mean CD4 cell count than nonresponders. It is expected that pegIFN- $\alpha$ will have similar or better efficacy than standard IFN- $\alpha$.

Lamivudine, emtricitabine and tenofovir are NAs with activity against both HIV and HBV. ${ }^{234,258,259}$ However, the rate of HBV resistance to lamivudine in HBV/HIV coinfected patients is high, reaching $90 \%$ at 4 years. ${ }^{259}$ Tenofovir plus lamivudine or emtricitabine are commonly prescribed as components of HAART in HBV/ HIV coinfected patients. Furthermore, tenofovir is effective against lamivudine-resistant $\mathrm{HBV}^{233}$ and appears to reduce the rate of lamivudine resistance when the combination is used. ${ }^{260}$

Adefovir at the approved dose for HBV (10 mg) has negligible activity against HIV. To date, no resistance to HIV has been detected up to 144 weeks in small studies. ${ }^{261}$ Entecavir has no activity against HIV. Telbivudine also has no activity against HIV but it should not be used in $\mathrm{HBV} / \mathrm{HIV}$ coinfected patients because of the risk of selection of M204I mutation in the YMDD motif.

Given that antiretroviral regimens may include drugs with activity against $\mathrm{HBV}$, it is reasonable to base HBV treatment decisions on whether or not HIV treatment is ongoing or planned. In HBeAg-positive patients who are not in need of HAART, or who are already well-controlled on HAART that does not include a drug with activity against $\mathrm{HBV}$, pegIFN- $\alpha$ may be considered as a first-line option given its limited duration, but adefovir or 
entecavir can also be used in this setting. It is generally recommended that candidates for IFN- $\alpha$ therapy have CD 4 cell counts $>500$ cells/uL. Patients who have lower CD 4 cell counts or who are HBeAg-negative may be appropriate candidates for adefovir or entecavir. Finally, in HBeAg-negative patients who are likely to need HIV treatment in the future, earlier initiation of HAART may be considered.

For patients in whom HAART initiation is planned, it is best to use a regimen that includes a drug/drugs with activity against $\mathrm{HBV}$. Most experts recommend using two drugs, while others suggest that a single agent may be sufficient in those with low HBV DNA levels. In patients with cirrhosis who are newly started on HAART, two drugs are preferred given the risk of a clinically significant hepatitis flare in the setting of immune reconstitution. In the setting of confirmed lamivudine resistance in patients who are already on HAART, adding tenofovir is generally preferred, but adding adefovir is also an option.

Hepatitis flares may occur when HBV treatment is discontinued, particularly in the absence of HBeAg seroconversion. Thus, when HAART regimens are altered, drugs that are effective against HBV should not be discontinued without substituting another drug that has activity against $\mathrm{HBV}$, unless the patient has achieved $\mathrm{HBeAg}$ seroconversion and has completed an adequate course of consolidation treatment.

\section{Recommendations for Treatment of Patients with HBVIHIV Coinfection}

32. Patients who meet criteria for chronic hepatitis B should be treated. (III)

- Liver biopsy should be considered in patients with fluctuating or mildly elevated ALT (1-2 x normal). (II-3)

33. Patients who are not on HAART and are not anticipated to require HAART in the near future should be treated with an antiviral therapy that does not target HIV, such as pegIFN- $\alpha$, adefovir or entecavir. Although telbivudine does not target HIV, it should not be used in this circumstance. (II-3)

34. Patients in whom treatment for both HBV and HIV is planned should receive therapies that are effective against both viruses: lamivudine plus tenofovir or emtricitabine plus tenofovir are preferred. (II-3)

35. Patients who are already on effective HAART that does not include a drug active against $\mathrm{HBV}$ may be treated with pegIFN $\alpha$, adefovir or entecavir. (II-3)

36. In patients with lamivudine resistance, tenofovir or adefovir should be added. (III)

37. When HAART regimens are altered, drugs that are effective against HBV should not be discontinued without substituting another drug that has activity against $\mathrm{HBV}$, unless the patient has achieved $\mathrm{HBeAg}$ seroconversion and has completed an adequate course of consolidation treatment. (II-3)

\section{Antiviral Prophylaxis of Hepatitis B Carriers Who Receive Immunosuppressive or Cytotoxic Chemotherapy}

Reactivation of HBV replication with increase in serum HBV DNA and ALT level has been reported in 20\% to $50 \%$ of hepatitis B carriers undergoing immunosuppressive or cancer chemotherapy. In most instances, the hepatitis flares are asymptomatic, but icteric flares, and even hepatic decompensation and death have been observed. ${ }^{262-264}$ Reactivation of HBV replication is more common when chemotherapeutic regimens that include corticosteroids are used. ${ }^{265}$ In addition, reactivations have been reported in $\mathrm{HBsAg}$-positive persons after intra-arterial chemoembolization for HCC and other immunosuppressive therapies such as rituximab for lymphoma as well as infliximab and other anti-tumor necrosis factor (TNF) therapies for rheumatoid arthritis or inflammatory bowel disease. ${ }^{264,266,267}$ Clinical studies including one controlled trial showed that prophylactic therapy with lamivudine can reduce the rate of HBV reactivation, severity of associated hepatitis flares and mortality. ${ }^{264,268-271} \mathrm{HBsAg}$ testing should be performed in persons who have high risk of HBV infection (see Table 2), prior to initiation of chemoor immunosuppressive therapy. Prophylactic antiviral therapy should be administered to hepatitis B carriers at the onset of cancer chemotherapy or a finite course of immunosuppressive therapy, and maintained for 6 months afterwards. Viral relapse after withdrawal of lamivudine has been reported in patients with high pre-chemotherapy DNA level, ${ }^{272} \mathrm{HBsAg}$-positive persons with serum HBV DNA levels $>2,000 \mathrm{IU} / \mathrm{ml}$ prior to undergoing cytotoxic chemotherapy should continue antiviral therapy until they reach therapeutic endpoints for chronic hepatitis B.

In the renal transplant setting, a small study found that most $\mathrm{HBsAg}$ positive patients had increase in serum $\mathrm{HBV}$ DNA levels necessitating lamivudine treatment. ${ }^{271}$ While studies to date have focused on lamivudine, adefovir or entecavir could be used as an alternate treatment, particularly in patients who are anticipated to require more than 12 months of therapy in whom there is a higher risk of resistance to lamivudine. In general, lamivudine and entecavir are preferred because of their rapid onset of action and lack of nephrotoxicity. IFN- $\alpha$ should not be used in this setting because of its bone marrow suppressive effects and the risk of hepatitis flares. 
While HBV reactivation can occur in persons who are $\mathrm{HBsAg}$ negative but anti-HBc and anti-HBs positive and in those with isolated anti-HBc, this is infrequent, and there is not enough information to recommend routine prophylaxis for these individuals. ${ }^{262,264}$

Recommendations for Treatment of Hepatitis $B$ carriers Who Require Immunosuppressive or Cytotoxic Therapy

38. HBsAg testing should be performed in patients who are at high risk of $\mathrm{HBV}$ infection (see recommendation number 1 ), prior to initiation of chemotherapy or immunosuppressive therapy. (II-3)

39. Prophylactic antiviral therapy is recommended for HBV carriers at the onset of cancer chemotherapy or of a finite course of immunosuppressive therapy.

a. Patients with baseline HBV DNA <2,000 IU/ml level should continue treatment for 6 months after completion of chemotherapy or immunosuppressive therapy. (III)

b. Patients with high baseline HBV DNA $(>2,000$ $\mathrm{IU} / \mathrm{ml}$ ) level should continue treatment until they reach treatment endpoints as in immunocompetent patients. (III)

c. Lamivudine or telbivudine can be used if the anticipated duration of treatment is short $(\leq 12$ months). (I for lamivudine and III for telbivudine)

d. Adefovir or entecavir is preferred if longer duration of treatment is anticipated. Entecavir has more rapid onset of action than adefovir and may be more appropriate in this setting. (III)

e. IFN- $\alpha$ should be avoided in view of the bone marrow suppressive effect. (II-3)

\section{Symptomatic Acute Hepatitis B}

Antiviral therapy is generally not necessary in patients with symptomatic acute hepatitis B because $>95 \%$ of immunocompetent adults with acute hepatitis B recover spontaneously. Small case series with or without comparisons to historical untreated controls have reported that lamivudine improves survival in patients with severe or fulminant hepatitis B. ${ }^{273,274}$ Limited data including one prospective randomized controlled trial of IFN- $\alpha$ showed that antiviral therapy did not decrease the rate of progression to chronic infection because all the study subjects had resolution of infection. ${ }^{275}$

Despite the lack of properly designed studies, an argument can be made for treating all patients with fulminant hepatitis B using a NA given its safety and the fact that many of these patients will ultimately need liver transplantation. At the $2006 \mathrm{NIH} \mathrm{HBV} \mathrm{Meeting,} \mathrm{it} \mathrm{was} \mathrm{also}$ proposed patients with protracted, severe acute hepatitis $\mathrm{B}$ (increase in INR and deep jaundice persisting for $>4$ weeks) be treated. (4) Lamivudine or telbivudine would be a reasonable choice given their safety and rapidity of action, and the short anticipated duration of therapy except in patients who proceed to transplant. Entecavir can also be used but adefovir may not be optimal because of its slow action and potential for nephrotoxicity. IFN- $\alpha$ is contraindicated because of the risks of worsening hepatitis and the frequent side effects.

Recommendations for Treatment of Patients with Acute Symptomatic Hepatitis B

40. Treatment is only indicated for patients with fulminant hepatitis B and those with protracted, severe acute hepatitis $B$. (III)

41. Lamivudine, telbivudine or entecavir is preferred. (II-3)

a. Treatment should be continued until HBsAg clearance is confirmed or indefinitely in those who undergo liver transplantation. (II-1)

b. IFN- $\alpha$ is contraindicated. (III)

Acknowledgment: This guideline was produced in collaboration with the Practice Guidelines Committee of the American Association for the Study of Liver Diseases. This committee provided extensive peer review of the manuscript. Members of the Practice Guidelines Committee include Margaret C. Shuhart, M.D., M.S., (Chair), Andres Cardenas, M.D., M.M.Sc., Stanley M. Cohen, M.D., Timothy J. Davern, M.D., Steven L. Flamm, M.D., Steven-Huy B. Han, M.D., Charles D. Howell, M.D., David R. Nelson, M.D., K. Rajender Reddy, M.D., Bruce A. Runyon, M.D., John B. Wong, M.D., and Nizar N. Zein, M.D.

\section{References}

1. Eddy DM. A Manual for Assessing Health Practices and Designing Practice Guidelines. Philadelphia. American College of Physicians, 1996:1126.

2. American Gastroenterological Association policy statement on the use of medical practice guidelines by managed care organizations and insurance carriers. Gastroenterology 1995;108:925-926.

3. Lok AS, Heathcote EJ, Hoofnagle JH. Management of hepatitis B: 2000 - summary of a workshop. Gastroenterology 2001;120:18281853.

4. Hoofnagle JH, Doo E, Liang TJ, Fleischer R, Lok ASF. Management of Hepatitis B: Summary of a Clinical Research Workshop. HePATOLOGY (submitted).

5. EASL International Consensus Conference on Hepatitis B. 13-14 September, 2002: Geneva, Switzerland. Consensus statement (short version). J Hepatol 2003;38:533-540.

6. Liaw YF, Leung N, Guan R, Lau GK, Merican I, McCaughan G, et al. Asian-Pacific consensus statement on the management of chronic hepatitis B: a 2005 update. Liver Int 2005;25:472-489.

7. Lavanchy D. Hepatitis B virus epidemiology, disease burden, treatment, and current and emerging prevention and control measures. J Viral Hepat 2004;11:97-107

8. McQuillan GM, Coleman PJ, Kruszon-Moran D, Moyer LA, Lambert SB, Margolis HS. Prevalence of hepatitis B virus infection in the United States: the National Health and Nutrition Examination Surveys, 1976 through 1994. [see comments]. Am J Public Health 1999;89:14-18. 
9. Mast EE, Margolis HS, Fiore AE, Brink EW, Goldstein ST, Wang SA, et al. A comprehensive immunization strategy to eliminate transmission of hepatitis B virus infection in the United States: recommendations of the Advisory Committee on Immunization Practices (ACIP) part 1: immunization of infants, children, and adolescents. MMWR Recomm Rep 2005;54:1-31.

9a. Mast EE, Weinbaum CM, Fiore AE, Alter MJ, Bell BP, Finelli L, et al. A comprehensive immunization strategy to eliminate transmission of hepatitis B virus infection in the United States-recommendations of the Advisory Committee on Immunization Practices (ACIP) Part II: Immunization of adults. MMWR 2006;55(RR-16):1-33.

10. Beasley RP. Hepatitis B virus. The major etiology of hepatocellular carcinoma. Cancer 1988;61:1942-1956.

11. Bosch FX, Ribes J, Cleries R, Diaz M. Epidemiology of hepatocellular carcinoma. Clin Liver Dis 2005;9:191-211, v.

12. Terrault N, Roche B, Samuel D. Management of the hepatitis B virus in the liver transplantation setting: a European and an American perspective. Liver Transpl 2005;11:716-732.

13. McMahon BJ. Epidemiology and natural history of hepatitis B. Semin Liver Dis 2005;25(Suppl 1):3-8.

14. Mast EE, Alter MJ, Margolis HS. Strategies to prevent and control hepatitis B and C virus infections: a global perspective. Vaccine 1999;17: 1730-1733.

15. Bond WW, Favero MS, Petersen NJ, Gravelle CR, Ebert JW, Maynard JE. Survival of hepatitis B virus after drying and storage for one week. Lancet 1981;1:550-551.

16. Petersen NJ, Barrett DH, Bond WW, Berquist KR, Favero MS, Bender TR, Maynard JE. Hepatitis B surface antigen in saliva, impetiginous lesions, and the environment in two remote Alaskan villages. Appl Environ Microbiol 1976;32:572-574.

17. Beasley RP, Hwang LY, Lee GC, Lan CC, Roan CH, Huang FY, et al. Prevention of perinatally transmitted hepatitis $\mathrm{B}$ virus infections with hepatitis B virus infections with hepatitis B immune globulin and hepatitis B vaccine. Lancet 1983;2:1099-1102.

18. Beasley RP, Hwang LY, Lin CC, Leu ML, Stevens CE, Szmuness W, et al. Incidence of hepatitis B virus infections in preschool children in Taiwan. J Infect Dis 1982;146:198-204.

19. Coursaget P, Yvonnet B, Chotard J, Vincelot P, Sarr M, Diouf C, et al. Age- and sex-related study of hepatitis B virus chronic carrier state in infants from an endemic area (Senegal). J Med Virol 1987;22:1-5.

20. McMahon BJ, Alward WL, Hall DB, Heyward WL, Bender TR, Francis $\mathrm{DP}$, et al. Acute hepatitis B virus infection: relation of age to the clinical expression of disease and subsequent development of the carrier state. J Infect Diseases 1985;151:599-603.

21. Tassopoulos NC, Papaevangelou GJ, Sjogren MH, Roumeliotou-Karayannis A, Gerin JL, Purcell RH. Natural history of acute hepatitis B surface antigen-positive hepatitis in Greek adults. Gastroenterology 1987;92: 1844-1850

22. Horvath J, Raffanti SP. Clinical aspects of the interactions between human immunodeficiency virus and the hepatotropic viruses. Clin Infect Dis 1994;18:339-347.

23. Bodsworth N, Donovan B, Nightingale BN. The effect of concurrent human immunodeficiency virus infection on chronic hepatitis B: a study of 150 homosexual men. J Infect Dis 1989;160:577-582.

24. Gandhi RT, Wurcel A, Lee HC, McGovern B, Boczanowski M, Gerwin $\mathrm{R}$, et al. Isolated antibody to hepatitis $\mathrm{B}$ core antigen in human immunodeficiency virus type-1-infected individuals. Clin Infect Dis 2003;36: 1602-1605.

25. Lok AS, Lai CL, Wu PC. Prevalence of isolated antibody to hepatitis B core antigen in an area endemic for hepatitis $\mathrm{B}$ virus infection: implications in hepatitis B vaccination programs. HePATOLOGY 1988;8:766-770.

26. McMahon BJ, Parkinson AJ. Clinical significance and management when antibody to hepatitis B core antigen is the sole marker for HBV infection. Viral Hep Rev 2000;6:229-236.

27. Villa ERL, Barchi T, Ferretti I, Grisendi A, De Palma M, Bellentani S, et al. Susceptiblility of chronic symptomless $\mathrm{HBs} A g$ carriers to ethanolinduced hepatic damage. Lancet 1982:1243-1245.
28. Chevillotte G, Durbec JP, Gerolami A, Berthezene P, Bidart JM, Camatte R. Interaction between hepatitis B virus and alcohol consumption in liver cirrhosis: An epidemiologic study. Gastroenterology 1983:141145 .

29. Wong VC, Ip HM, Reesink HW, Lelie PN, Reerink-Brongers EE, Yeung $\mathrm{CY}$, et al. Prevention of the HBsAg carrier state in newborn infants of mothers who are chronic carriers of $\mathrm{HBsAg}$ and $\mathrm{HBeAg}$ by administration of hepatitis-B vaccine and hepatitis-B immunoglobulin. Doubleblind randomised placebo-controlled study. Lancet 1984;1:921-926.

30. Harpaz R, Von Seidlein L, Averhoff FM, Tormey MP, Sinha SD, Kotsopoulou $\mathrm{K}$, et al. Transmission of hepatitis $\mathrm{B}$ virus to multiple patients from a surgeon without evidence of inadequate infection control. [see comments]. N Engl J Med 1996;334:549-554.

31. Gerberding JL. The infected health care provider. [letter; comment]. [see comments]. N Engl J Med 1996;334:594-595.

32. CDC. Recommendations for preventing transmission of human immunodeficiency virus and hepatitis B virus to patients during exposure-prone invasive procedures. MMWR 1991;40:1-7.

33. Gunson RN, Shouval D, Roggendorf M, Zaaijer H, Nicholas H, Holzmann $\mathrm{H}$, et al. Hepatitis B virus (HBV) and hepatitis $\mathrm{C}$ virus (HCV) infections in health care workers (HCWs): guidelines for prevention of transmission of HBV and HCV from HCW to patients. J Clin Virol 2003;27:213-230.

34. Buster EH, van der Eijk AA, Schalm SW. Doctor to patient transmission of hepatitis B virus: implications of HBV DNA levels and potential new solutions. Antiviral Res 2003;60:79-85.

35. Wachs ME, Amend WJ, Ascher NL, Bretan PN, Emond J, Lake JR, et al. The risk of transmission of hepatitis B from $\mathrm{HBsAg}(-), \mathrm{HBcAb}(+)$, $\operatorname{HBIgM}(-)$ organ donors. Transplantation 1995;59:230-234.

36. Dickson RC, Everhart JE, Lake JR, Wei Y, Seaberg EC, Wiesner RH, et al. Transmission of hepatitis $\mathrm{B}$ by transplantation of livers from donors positive for antibody to hepatitis B core antigen. The National Institute of Diabetes and Digestive and Kidney Diseases Liver Transplantation Database. Gastroenterology 1997;113:1668-1674.

37. Prieto M, Gomez MD, Berenguer M, Cordoba J, Rayon JM, Pastor M, et al. De novo hepatitis B after liver transplantation from hepatitis B core antibody-positive donors in an area with high prevalence of anti-HBc positivity in the donor population. Liver Transpl 2001;7:51-58.

38. Mutimer D. Review article: hepatitis B and liver transplantation. Aliment Pharmacol Ther 2006;23:1031-1041.

39. Fung SK, Lok AS. Hepatitis B virus genotypes: do they play a role in the outcome of HBV infection? HePATOLOGY 2004;40:790-792.

40. Norder H, Courouce AM, Coursaget P, Echevarria JM, Lee SD, Mushahwar IK, et al. Genetic diversity of hepatitis B virus strains derived worldwide: genotypes, subgenotypes, and $\mathrm{HBsAg}$ subtypes. Intervirology 2004;47:289-309.

41. Chu CJ, Keeffe EB, Han SH, Perrillo RP, Min AD, Soldevila-Pico C, et al. Hepatitis B virus genotypes in the United States: results of a nationwide study. Gastroenterology 2003;125:444-451.

42. Chan HL, Hui AY, Wong ML, Tse AM, Hung LC, Wong VW, et al. Genotype $\mathrm{C}$ hepatitis $\mathrm{B}$ virus infection is associated with an increased risk of hepatocellular carcinoma. Gut 2004;53:1494-1498.

43. Chu CJ, Hussain M, Lok AS. Hepatitis B virus genotype B is associated with earlier $\mathrm{HBeAg}$ seroconversion compared with hepatitis B virus genotype C. Gastroenterology 2002;122:1756-1762.

44. Kao JH, Chen PJ, Lai MY, Chen DS. Hepatitis B genotypes correlate with clinical outcomes in patients with chronic hepatitis B. Gastroenterology 2000;118:554-559.

45. Chu CM, Liaw YF. Genotype C hepatitis B virus infection is associated with a higher risk of reactivation of hepatitis $\mathrm{B}$ and progression to cirrhosis than genotype $\mathrm{B}$ : a longitudinal study of hepatitis $\mathrm{B}$ e antigen-positive patients with normal aminotransferase levels at baseline. J Hepatol 2005; 43:411-417.

46. Sumi H, Yokosuka O, Seki N, Arai M, Imazeki F, Kurihara T, et al. Influence of hepatitis $\mathrm{B}$ virus genotypes on the progression of chronic type B liver disease. Hepatology 2003;37:19-26. 
47. Yu MW, Yeh SH, Chen PJ, Liaw YF, Lin CL, Liu CJ, et al. Hepatitis B virus genotype and DNA level and hepatocellular carcinoma: a prospective study in men. J Natl Cancer Inst 2005;97:265-272.

48. Kao JH, Wu NH, Chen PJ, Lai MY, Chen DS. Hepatitis B genotypes and the response to interferon therapy. J Hepatol 2000;33:998-1002.

49. Wai CT, Chu CJ, Hussain M, Lok AS. HBV genotype B is associated with better response to interferon therapy in $\mathrm{HBeAg}(+)$ chronic hepatitis than genotype C. Hepatology 2002;36:1425-1430.

50. Erhardt A, Blondin D, Hauck K, Sagir A, Kohnle T, Heintges T, et al. Response to interferon alfa is hepatitis $\mathrm{B}$ virus genotype dependent: genotype A is more sensitive to interferon than gentoype D. Gut 2005;54: 1009-1013

51. Janssen HL, van Zonneveld M, Senturk H, Zeuzem S, Akarca US, Cakaloglu Y, et al. Pegylated interferon alfa- $2 \mathrm{~b}$ alone or in combination with lamivudine for $\mathrm{HBeAg}$-positive chronic hepatitis $\mathrm{B}$ : a randomised trial. Lancet 2005;365:123-129.

52. Lau GK, Piratvisuth T, Luo KX, Marcellin P, Thongsawat S, Cooksley G, et al. Peginterferon Alfa-2a, lamivudine, and the combination for HBeAg-positive chronic hepatitis B. N Engl J Med 2005;352:26822695.

53. Hoofnagle JH, Dusheiko GM, Seeff LB, Jones EA, Waggoner JG, Bales ZB. Seroconversion from hepatitis B e antigen to antibody in chronic type B hepatitis. Ann Intern Med 1981;94:744-748.

54. Liaw YF, Chu CM, Su IJ, Huang MJ, Lin DY, Chang-Chien CS. Clinical and histological events preceding hepatitis $\mathrm{B}$ e antigen seroconversion in chronic type B hepatitis. Gastroenterology 1983;84:216-219.

55. Fattovich G, Rugge M, Brollo L, Pontisso P, Noventa F, Guido M, et al. Clinical, virologic and histologic outcome following seroconversion from HBeAg to anti-HBe in chronic hepatitis type B. Hepatology 1986;6: 167-172.

56. Lok AS, Lai CL, Wu PC, Leung EK, Lam TS. Spontaneous hepatitis B e antigen to antibody seroconversion and reversion in Chinese patients with chronic hepatitis B virus infection. Gastroenterology 1987;92:18391843.

57. Lok AS, Lai CL. A longitudinal follow-up of asymptomatic hepatitis B surface antigen-positive Chinese children. HePATOLOGY 1988;8:11301133.

58. Chang MH, Hsu HY, Hsu HC, Ni YH, Chen JS, Chen DS. The significance of spontaneous hepatitis $\mathrm{B}$ e antigen seroconversion in childhood: with special emphasis on the clearance of hepatitis B e antigen before 3 years of age. Hepatology 1995;22:1387-1392.

59. Lee PI, Chang MH, Lee CY, Hsu HY, Chen JS, Chen PJ, et al. Changes of serum hepatitis B virus DNA and aminotransferase levels during the course of chronic hepatitis B virus infection in children. HEPATOLOGY 1990;12:657-660

60. Lok AS, Lai CL. Acute exacerbations in Chinese patients with chronic hepatitis $\mathrm{B}$ virus (HBV) infection. Incidence, predisposing factors and etiology. J Hepatol 1990;10:29-34.

61. Dusheiko GM, Brink BA, Conradie JD, Marimuthu T, Sher R. Regional prevalence of hepatitis $B$, delta, and human immunodeficiency virus infection in southern Africa: a large population survey. Am J Epidemiol 1989;129:138-145.

62. Bortolotti F, Guido M, Bartolacci S, Cadrobbi P, Crivellaro C, Noventa $\mathrm{F}$, et al. Chronic hepatitis B in children after e antigen seroclearance: final report of a 29-year longitudinal study. Hepatology 2006;43:556-562.

63. Moreno MR, Otero M, Millan A, Castillo I, Cabrerizo M, Jimenez FJ, et al. Clinical and histological outcome after hepatitis B e antigen to antibody seroconversion in children with chronic hepatitis B. HEPATOLOGY 1999:572-575.

64. Stroffolini T, Mele A, Tosti ME, Gallo G, Balocchini E, Ragni P, et al. The impact of the hepatitis $B$ mass immunisation campaign on the incidence and risk factors of acute hepatitis B in Italy. J Hepatol 2000;33: 980-985.

65. McMahon BJ, Holck P, Bulkow L, Snowball MM. Serologic and clinical outcomes 1536 Alaska Natives chronically infected with hepatitis B virus. Ann Intern Med 2001:759-768.
66. Colin JF, Cazals-Hatem D, Loriot MA, Martinot-Peignoux M, Pham $\mathrm{BN}$, Auperin A, et al. Influence of human immunodeficiency virus infection on chronic hepatitis B in homosexual men. Hepatology 1999: 1306-1310.

67. Hsu YS, Chien RN, Yeh CT, Sheen IS, Chiou HY, Chu CM, et al Long-term outcome after spontaneous $\mathrm{HBeAg}$ seroconversion in patients with chronic hepatitis B. Hepatology 2002;35:1522-1527.

68. Davis GL, Hoofnagle JH, Waggoner JG. Spontaneous reactivation of chronic hepatitis B virus infection. Gastroenterology 1984;86:230-235.

69. Fattovich G, Giustina G, Schalm SW, Hadziyannis S, Sanchez-Tapias J, Almasio P, et al. Occurrence of hepatocellular carcinoma and decompensation in western European patients with cirrhosis type B. The EUROHEP Study Group on Hepatitis B Virus and Cirrhosis. HepatologY 1995;21:77-82.

70. Niederau C, Heintges T, Lange S, Goldmann G, Niederau CM, Mohr L, et al. Long-term follow-up of HBeAg-positive patients treated with interferon alfa for chronic hepatitis B. [see comments]. New Engl J Med 1996;334:1422-1427.

71. de Jongh FE, Janssen HL, de Man RA, Hop WC, Schalm SW, van Blankenstein M. Survival and prognostic indicators in hepatitis B surface antigen-positive cirrhosis of the liver. [see comments]. Gastroenterology 1992;103:1630-1635.

72. Yu MW, Hsu FC, Sheen IS, Chu CM, Lin DY, Chen CJ, et al. Prospective study of hepatocellular carcinoma and liver cirrhosis in asymptomatic chronic hepatitis B virus carriers. Am J Epidemiol 1997;145:1039-1047.

73. Fattovich G, Brollo L, Giustina G, Noventa F, Pontisso P, Alberti A, et al Natural history and prognostic factors for chronic hepatitis type B. Gut 1991;32:294-298.

74. Fattovich G, Giustina G, Realdi G, Corrocher R, Schalm SW. Long-term outcome of hepatitis $\mathrm{B}$ e antigen-positive patients with compensated cirrhosis treated with interferon alfa. European Concerted Action on Viral Hepatitis (EUROHEP). Hepatology 1997;26:1338-1342.

75. Lin SM, Sheen IS, Chien RN, Chu CM, Liaw YF. Long-term beneficial effect of interferon therapy in patients with chronic hepatitis B virus infection. Hepatology 1999;29:971-975.

76. Lau DT, Everhart J, Kleiner DE, Park Y, Vergalla J, Schmid P, et al. Long-term follow-up of patients with chronic hepatitis B treated with interferon alfa. Gastroenterology 1997;113:1660-1667.

77. Liaw YF, Sung JJ, Chow WC, Farrell G, Lee CZ, Yuen H, et al. Lamivudine for patients with chronic hepatitis $\mathrm{B}$ and advanced liver disease. N Engl J Med 2004;351:1521-1531.

78. Hadziyannis SJ, Vassilopoulos D. Hepatitis B e antigen-negative chronic hepatitis B. Hepatology 2001;34:617-624.

79. Chan HL, Leung NW, Hussain M, Wong ML, Lok AS. Hepatitis B e antigen-negative chronic hepatitis B in Hong Kong. HePATOLOGY 2000; 31:763-768

80. Lindh M, Andersson AS, Gusdal A. Genotypes, nt 1858 variants, and geographic origin of hepatitis B virus-large-scale analysis using a new genotyping method. J Infect Dis 1997;175:1285-1293.

81. Naoumov NV, Schneider R, Grotzinger T, Jung MC, Miska S, Pape GR. Precore mutant hepatitis B virus infection and liver disease. Gastroenterology 1992:538-543.

82. Grandjacques C, Pradat P, Stuyver L, Chevallier M, Chevallier P, Pichoud $\mathrm{C}$, et al. Rapid detection of genotypes and mutations in the precore promoter and the pre-core region of hepatitis $\mathrm{B}$ virus genome: correlation with viral persistence and disease severity. J Hepatol 2000;33: 430-439.

83. Brunetto MR, Giarin MM, Oliveri F, Chiaberge E, Baldi M, Alfarano A, et al. Wild-type and e antigen-minus hepatitis $\mathrm{B}$ viruses and course of chronic hepatitis. Proc Natl Acad Sci U S A 1991;88:4186-4190.

84. Lok AS, Akarca U, Greene S. Mutations in the pre-core region of hepatitis $B$ virus serve to enhance the stability of the secondary structure of the pre-genome encapsidation signal. Proc Natl Acad Sci U S A 1994;91: 4077-4081.

85. Okamoto H, Tsuda F, Akahane Y, Sugai Y, Yoshiba M, Moriyama K, et al. Hepatitis $B$ virus with mutations in the core promoter for an e antigen- 
negative phenotype in carriers with antibody to e antigen. J Virol 1994; 68:8102-8110.

86. Brunetto MR, Oliveri F, Coco B, Leandro G, Colombatto P, Gorin JM, et al. Outcome of anti-HBe positive chronic hepatitis B in alpha-interferon treated and untreated patients: a long term cohort study. J Hepatol 2002;36:263-270

87. Liaw YF, Sheen IS, Chen TJ, Chu CM, Pao CC. Incidence, determinants and significance of delayed clearance of serum $\mathrm{HBsAg}$ in chronic hepatitis B virus infection: a prospective study. HePaTOlogy 1991;13:627-631.

88. Ahn SH, Park YN, Park JY, Chang HY, Lee JM, Shin JE, et al. Long-term clinical and histological outcomes in patients with spontaneous hepatitis B surface antigen seroclearance. J Hepatol 2005;42:188-194.

89. Chen YC, Sheen IS, Chu CM, Liaw YF. Prognosis following spontaneous HBsAg seroclearance in chronic hepatitis B patients with or without concurrent infection. Gastroenterology 2002;123:1084-1089.

90. Yuen MF, Wong DK, Sablon E, Tse E, Ng IO, Yuan HJ, et al. HBsAg seroclearance in chronic hepatitis B in the Chinese: virological, histological, and clinical aspects. Hepatology 2004;39:1694-1701.

91. Huo TI, Wu JC, Lee PC, Chau GY, Lui WY, Tsay SH, et al. Seroclearance of hepatitis B surface antigen in chronic carriers does not necessarily imply a good prognosis. [see comments]. HePATOLOGY 1998;28: 231-236.

92. Yim HJ, Lok AS. Natural history of chronic hepatitis B virus infection: what we knew in 1981 and what we know in 2005. Hepatology 2006; 43:S173-181.

93. Fattovich G. Natural history and prognosis of hepatitis B. Semin Liver Dis 2003;23:47-58

94. Yang HI, Lu SN, Liaw YF, You SL, Sun CA, Wang LY, et al. Hepatitis B e antigen and the risk of hepatocellular carcinoma. New Engl Jo Med 2002;347:168-174

95. Harris RA, Chen G, Lin WY, Shen FM, London WT, Evans AA. Spontaneous clearance of high-titer serum HBV DNA and risk of hepatocellular carcinoma in a Chinese population. Cancer Causes Control 2003; 14:995-1000

96. Iloeje UH, Yang HI, Su J, Jen CL, You SL, Chen CJ. Predicting cirrhosis risk based on the level of circulating hepatitis B viral load. Gastroenterology 2006;130:678-686.

97. Chen CJ, Yang HI, Su J, Jen CL, You SL, Lu SN, et al. Risk of hepatocellular carcinoma across a biological gradient of serum hepatitis $\mathrm{B}$ virus DNA level. JAMA 2006;295:65-73.

98. Strader DB. Understudied populations with hepatitis C. HePATOLOGY 2002;36(Suppl):S226-S236

99. Mimms LT, Mosley JW, Hollinger FB, Aach RD, Stevens CE, Cunningham $\mathrm{M}$, et al. Effect of concurrent acute infection with hepatitis $\mathrm{C}$ virus on acute hepatitis B virus infection. [see comments]. BMJ 1993;307: 1095-1097.

100. Liaw YF, Tsai SL, Chang JJ, Sheen IS, Chien RN, Lin DY, et al. Displacement of hepatitis $\mathrm{B}$ virus by hepatitis $\mathrm{C}$ virus as the cause of continuing chronic hepatitis. Gastroenterology 1994;106:1048-1053.

101. Chu CM, Yeh CT, Liaw YF. Fulminant hepatic failure in acute hepatitis C: increased risk in chronic carriers of hepatitis B virus. Gut 1999;45: 613-617.

102. Liaw YF, Chen YC, Sheen IS, Chien RN, Yeh CT, Chu CM. Impact of acute hepatitis $\mathrm{C}$ virus superinfection in patients with chronic hepatitis $\mathrm{B}$ virus infection. Gastroenterology 2004;126:1024-1029.

103. Donato F, Boffetta P, Puoti M. A meta-analysis of epidemiological studies on the combined effect of hepatitis $\mathrm{B}$ and $\mathrm{C}$ virus infections in causing hepatocellular carcinoma. Int J Cancer 1998;75:347-354.

104. Hadziyannis SJ. Hepatitis D. Clin Liver Dis 1999:309-325.

105. Gaeta GB, Stroffolini T, Chiaramonte M, Ascione T, Stornaiuolo G, Lobello S, et al. Chronic hepatitis D: a vanishing Disease? An Italian multicenter study. Hepatology 2000;32:824-827.

106. Caredda F, Rossi E, d'Arminio Monteforte A, Zampini L, Re T, Meroni B, et al. Hepatitis B virus-associated coinfection and superinfection with delta agent: Indistinguishable disease with different outcome. J Infect Dis 1985:925-928.
107. Fattovich G, Boscaro S, Noventa F, Pornaro E, Stenico D, Alberti A, et al. Influence of hepatitis delta virus infection on progression to cirrhosis in chronic hepatitis type B. J Infect Dis 1987;155:931-935.

108. Fattovich G, Giustina G, Christensen E, Pantalena M, Zagni I, Realdi G, et al. Influence of hepatitis delta virus infection on morbidity and mortality in compensated cirrhosis type B. The European Concerted Action on Viral Hepatitis (Eurohep). Gut 2000;46:420-426.

109. Housset C, Pol S, Carnot F, Dubois F, Nalpas B, Housset B, et al Interactions between human immunodeficiency virus-1, hepatitis delta virus and hepatitis B virus infections in 260 chronic carriers of hepatitis B virus. Hepatology 1992;15:578-583.

110. Soriano V, Puoti M, Bonacini M, Brook G, Cargnel A, Rockstroh J, et al. Care of patients with chronic hepatitis B and HIV co-infection: recommendations from an HIV-HBV International Panel. AIDS 2005; 19:221 240.

111. Alberti A, Clumeck N, Collins S, Gerlich W, Lundgren J, Palu G, et al. Short statement of the first European Consensus Conference on the treatment of chronic hepatitis B and C in HIV co-infected patients. J Hepatol 2005; $42: 615-624$

112. Thio CL, Seaberg EC, Skolasky R Jr, Phair J, Visscher B, Munoz A, et al. HIV-1, hepatitis B virus, and risk of liver-related mortality in the Multicenter Cohort Study (MACS). Lancet 2002;360:1921-1926.

113. Fiore AE, Wasley A, Bell BP. Prevention of hepatitis A through active or passive immunization: recommendations of the Advisory Committee on Immunization Practices (ACIP). MMWR Recomm Rep 2006;55:1-23.

114. Pawlotsky JM. Molecular diagnosis of viral hepatitis. Gastroenterology 2002;122:1554-1568.

115. Weiss J, Wu H, Farrenkopf B, Schultz T, Song G, Shah S, et al. Real time TaqMan PCR detection and quantitation of HBV genotypes A-G with the use of an internal quantitation standard. J Clin Virol 2004;30:86-93.

116. Rehermann B, Ferrari C, Pasquinelli C, Chisari FV. The hepatitis B virus persists for decades after patients' recovery from acute viral hepatitis despite active maintenance of a cytotoxic T-lymphocyte response. Nat Med 1996;2:1104-1108.

117. Chu CJ, Hussain M, Lok AS. Quantitative serum HBV DNA levels during different stages of chronic hepatitis B infection. HepatologY 2002;36:1408-1415.

118. Prati D, Taioli E, Zanella A, Della Torre E, Butelli S, Del Vecchio E, et al. Updated definitions of healthy ranges for serum alanine aminotransferase levels. Ann Intern Med 2002;137:1-10.

119. Liaw YF, Tai DI, Chu CM, Pao CC, Chen TJ. Acute exacerbation in chronic type B hepatitis: comparison between $\mathrm{HBeAg}$ and antibodypositive patients. Hepatology 1987;7:20-23.

120. Bruix J, Sherman M. Management of hepatocellular carcinoma. HEPATOLOGY 2005;42:1208-1236.

121. Bartholomeusz A, Locarnini SA. Antiviral drug resistance: clinical consequences and molecular aspects. Semin Liver Dis 2006;26:162-170.

122. Ono-Nita SK, Kato N, Shiratori Y, Masaki T, Lan KH, Carrilho FJ, et al. YMDD motif in hepatitis B virus DNA polymerase influences on replication and lamivudine resistance: A study by in vitro full-length viral DNA transfection. HePatology 1999;29:939-945.

123. Fung SK, Chae HB, Fontana RJ, Conjeevaram H, Marrero J, Oberhelman $\mathrm{K}$, et al. Virologic response and resistance to adefovir in patients with chronic hepatitis B. J Hepatol 2006;44:283-290.

124. Yim HJ, Hussain M, Liu Y, Wong SN, Fung S, Lok A. Evolution of multi-drug resistant hepatits $B$ viurs during sequential therapy: implications on rescue therapy. HePATOLOGY 2006;44:703-712.

125. Wong DK, Cheung AM, O'Rourke K, Naylor CD, Detsky AS, Heathcote J. Effect of alpha-interferon treatment in patients with hepatitis $\mathrm{B} e$ antigen-positive chronic hepatitis B. A meta-analysis. [see comments]. Ann Intern Med 1993;119:312-323

126. Brook MG, Karayiannis P, Thomas HC. Which patients with chronic hepatitis B virus infection will respond to alpha-interferon therapy? A statistical analysis of predictive factors. [see comments]. HepatologY 1989;10:761-763.

127. Perrillo RP, Schiff ER, Davis GL, Bodenheimer HC Jr, Lindsay K, Payne $\mathrm{J}$, et al. A randomized, controlled trial of interferon alfa- $2 \mathrm{~b}$ alone and after 
prednisone withdrawal for the treatment of chronic hepatitis B. The Hepatitis Interventional Therapy Group. [see comments]. New Engl J Med 1990;323:295-301.

128. Lok AS, Wu PC, Lai CL, Lau JY, Leung EK, Wong LS, et al. A controlled trial of interferon with or without prednisone priming for chronic hepatitis B. Gastroenterology 1992;102:2091-2097.

129. Lai CL, Lok AS, Lin HJ, Wu PC, Yeoh EK, Yeung CY. Placebo-controlled trial of recombinant alpha 2-interferon in Chinese HBsAg-carrier children. Lancet 1987;2:877-880.

130. Lai CL, Lin HJ, Lau JN, Flok AS, Wu PC, Chung HT, et al. Effect of recombinant alpha 2 interferon with or without prednisone in Chinese HBsAg carrier children. Q J Med 1991;78:155-163.

131. Lok AS, Lai CL, Wu PC, Leung EK. Long-term follow-up in a randomised controlled trial of recombinant alpha 2-interferon in Chinese patients with chronic hepatitis B infection. Lancet 1988;2:298-302.

132. Jara P, Bortolotti F. Interferon-alpha treatment of chronic hepatitis B in childhood: a consensus advice based on experience in European children. J Pediat Gastroenterol Nut 1999;29:163-170.

133. Gregorio GV, Jara P, Hierro L, Diaz C, de la Vega A, Vegnente A, et al. Lymphoblastoid interferon alfa with or without steroid pretreatment in children with chronic hepatitis B: a multicenter controlled trial. HePATOLOGY 1996;23:700-707.

134. Sokal EM, Conjeevaram HS, Roberts EA, Alvarez F, Bern EM, Goyens P, et al. Interferon alfa therapy for chronic hepatitis B in children: a multinational randomized controlled trial. Gastroenterology 1998;114:988995.

135. Torre D, Tambini R. Interferon-alpha therapy for chronic hepatitis B in children: a meta-analysis. Clin Infect Dis 1996;23:131-137.

136. Lampertico P, Del Ninno E, Manzin A, Donato MF, Rumi MG, Lunghi $\mathrm{G}$, et al. A randomized, controlled trial of a 24-month course of interferon alfa $2 \mathrm{~b}$ in patients with chronic hepatitis $\mathrm{B}$ who had hepatitis $\mathrm{B}$ virus DNA without hepatitis B e antigen in serum. Hepatology 1997;26: 1621-1625.

137. Fattovich G, Farci P, Rugge M, Brollo L, Mandas A, Pontisso P, et al. A randomized controlled trial of lymphoblastoid interferon-alpha in patients with chronic hepatitis B lacking HBeAg. HePatology 1992;15: 584-589.

138. Hadziyannis S, Bramou T, Makris A, Moussoulis G, Zignego L, Papaioannou C. Interferon alfa- $2 b$ treatment of $\mathrm{HBeAg}$ negative/serum HBV DNA positive chronic active hepatitis type B. J Hepatol 1990;11(Suppl 1):S133-S136.

139. Pastore G, Santantonio T, Milella M, Monno L, Mariano N, Moschetta $\mathrm{R}$, et al. Anti-HBe-positive chronic hepatitis B with HBV-DNA in the serum response to a 6-month course of lymphoblastoid interferon. J Hepatol 1992;14:221-225.

140. Papatheodoridis GV, Manesis E, Hadziyannis SJ. The long-term outcome of interferon-alpha treated and untreated patients with $\mathrm{HBeAg}-$ negative chronic hepatitis B. J Hepatol 2001;34:306-313.

141. Lampertico P, Del Ninno E, Vigano M, Romeo R, Donato MF, Sablon $\mathrm{E}$, et al. Long-term suppression of hepatitis $\mathrm{B}$ e antigen-negative chronic hepatitis B by 24-month interferon therapy. HePATOLOGY 2003;37:756763.

142. Manesis EK, Hadziyannis SJ. Interferon alpha treatment and retreatment of hepatitis B e antigen-negative chronic hepatitis B. Gastroenterology 2001;121:101-109.

143. Perrillo R, Tamburro C, Regenstein F, Balart L, Bodenheimer H, Silva $\mathrm{M}$, et al. Low-dose, titratable interferon alfa in decompensated liver disease caused by chronic infection with hepatitis B virus. Gastroenterology 1995;109:908-916.

144. Hoofnagle JH, Di Bisceglie AM, Waggoner JG, Park Y. Interferon alfa for patients with clinically apparent cirrhosis due to chronic hepatitis B. Gastroenterology 1993;104:1116-1121.

145. Lok AS, Chung HT, Liu VW, Ma OC. Long-term follow-up of chronic hepatitis B patients treated with interferon alfa. Gastroenterology 1993; 105:1833-1838.
146. Korenman J, Baker B, Waggoner J, Everhart JE, Di Bisceglie AM, Hoofnagle JH. Long-term remission of chronic hepatitis B after alphainterferon therapy. Annals of Internal Medicine 1991;114:629-634.

147. Krogsgaard K. The long-term effect of treatment with interferon-alpha $2 \mathrm{a}$ in chronic hepatitis B. The Long-Term Follow-up Investigator Group. The European Study Group on Viral Hepatitis (EUROHEP). Executive Team on Anti-Viral Treatment. J Viral Hepat 1998;5:389-397.

148. Carreno V, Castillo I, Molina J, Porres JC, Bartolome J. Long-term follow-up of hepatitis B chronic carriers who responded to interferon therapy. J Hepatol 1992;15:102-106.

149. Yuen MF, Hui CK, Cheng CC, Wu CH, Lai YP, Lai CL. Long-term follow-up of interferon alfa treatment in Chinese patients with chronic hepatitis B infection: The effect on hepatitis B e antigen seroconversion and the development of cirrhosis-related complications. HepatOlOGY 2001;34:139-145.

150. van Zonneveld M, Honkoop P, Hansen BE, Niesters HG, Murad SD, de Man RA, et al. Long-term follow-up of alpha-interferon treatment of patients with chronic hepatitis B. Hepatology 2004;39:804-810.

151. Cooksley WG, Piratvisuth T, Lee SD, Mahachai V, Chao YC, Tanwandee T, et al. Peginterferon alpha- $2 \mathrm{a}(40 \mathrm{kDa})$ : an advance in the treatment of hepatitis B e antigen-positive chronic hepatitis B. J Viral Hepat 2003; 10:298-305.

152. Chan HL, Leung NW, Hui AY, Wong VW, Liew CT, Chim AM, et al. A randomized, controlled trial of combination therapy for chronic hepatitis $\mathrm{B}$ : comparing pegylated interferon-alpha2b and lamivudine with lamivudine alone. Ann Intern Med 2005;142:240-250.

153. Marcellin P, Lau GK, Bonino F, Farci P, Hadziyannis S, Jin R, et al. Peginterferon alfa- $2 \mathrm{a}$ alone, lamivudine alone, and the two in combination in patients with $\mathrm{HBeAg}$-negative chronic hepatitis B. N Engl J Med 2004;351:1206-1217.

154. Dienstag JL, Schiff ER, Wright TL, Perrillo RP, Hann HW, Goodman $Z$, et al. Lamivudine as initial treatment for chronic hepatitis B in the United States. New Engl J Med 1999;341:1256-1263.

155. Lai CL, Chien RN, Leung NW, Chang TT, Guan R, Tai DI, et al. A one-year trial of lamivudine for chronic hepatitis B. Asia Hepatitis Lamivudine Study Group. [see comments]. New Engl J Med 1998;339:61-68.

156. Schalm SW, Heathcote J, Cianciara J, Farrell G, Sherman M, Willems B, et al. Lamivudine and alpha interferon combination treatment of patients with chronic hepatitis B infection: a randomised trial. [see comments]. Gut 2000;46:562-568.

157. Liaw YF, Leung NW, Chang TT, Guan R, Tai DI, Ng KY, et al. Effects of extended lamivudine therapy in Asian patients with chronic hepatitis B. Asia Hepatitis Lamivudine Study Group. [see comments]. Gastroenterology 2000;119:172-180.

158. Leung NW, Lai CL, Chang TT, Guan R, Lee CM, Ng KY, et al. Extended lamivudine treatment in patients with chronic hepatitis $\mathrm{B}$ enhances hepatitis $\mathrm{B}$ e antigen seroconversion rates: results after 3 years of therapy. Hepatology 2001;33:1527-1532.

159. Chang TT, Lai CL, Chien RN, Guan R, Lim SG, Lee CM, et al. Four years of lamivudine treatment in Chinese patients with chronic hepatitis B. J Gastroenterol Hepatol 2004;19:1276-1282.

160. Lok AS, Lai CL, Leung N, Yao GB, Cui ZY, Schiff ER, et al. Long-term safety of lamivudine treatment in patients with chronic hepatitis B. Gastroenterology 2003;125:1714-1722.

161. Chien RN, Liaw YF, Atkins M. Pretherapy alanine transaminase level as a determinant for hepatitis $\mathrm{B}$ e antigen seroconversion during lamivudine therapy in patients with chronic hepatitis B. Asian Hepatitis Lamivudine Trial Group. HePatology 1999;30:770-774.

162. Perrillo RP, Lai CL, Liaw YF, Dienstag JL, Schiff ER, Schalm SW, et al. Predictors of $\mathrm{HBeAg}$ loss after lamivudine treatment for chronic hepatitis B. Hepatology 2002;36:186-194.

163. Jonas MM, Kelley DA, Mizerski J, Badia IB, Areias JA, Schwarz KB, et al. Clinical trial of lamivudine in children with chronic hepatitis B. N Engl J Med 2002;346:1706-1713.

164. Sokal EM, Kelly DA, Mizerski J, Badia IB, Areias JA, Schwarz KB, et al. Long-term lamivudine therapy for children with $\mathrm{HBeAg}$-positive chronic hepatitis B. HePATOLOGY 2006;43:225-232. 
165. Tassopoulos NC, Volpes R, Pastore G, Heathcote J, Buti M, Goldin RD, et al. Efficacy of lamivudine in patients with hepatitis B e antigen-negative/hepatitis B virus DNA-positive (precore mutant) chronic hepatitis B. Lamivudine Precore Mutant Study Group. Hepatology 1999;29:889896.

166. Santantonio T, Mazzola M, Iacovazzi T, Miglietta A, Guastadisegni A, Pastore G. Long-term follow-up of patients with anti-HBe/HBV DNApositive chronic hepatitis B treated for 12 months with lamivudine. J Hepatol 2000;32:300-306.

167. Lok AS, Hussain M, Cursano C, Margotti M, Gramenzi A, Grazi GL, et al. Evolution of hepatitis B virus polymerase gene mutations in hepatitis $\mathrm{B}$ e antigen-negative patients receiving lamivudine therapy. [see comments]. Hepatology 2000;32:1145-1153.

168. Hadziyannis SJ, Papatheodoridis GV, Dimou E, Laras A, Papaioannou C. Efficacy of long-term lamivudine monotherapy in patients with hepatitis B e antigen-negative chronic hepatitis B. HePATOLOGY 2000;32: 847-851.

169. Lau DT, Khokhar MF, Doo E, Ghany MG, Herion D, Park Y, et al. Long-term therapy of chronic hepatitis B with lamivudine. HePATOLOGY 2000;32:828-834.

170. Rizzetto M, Volpes R, Smedile A. Response of pre-core mutant chronic hepatitis B infection to lamivudine. J Med Virol 2000;61:398-402.

171. Papatheodoridis GV, Dimou E, Laras A, Papadimitropoulos V, Hadziyannis SJ. Course of virologic breakthroughs under long-term lamivudine in $\mathrm{HBeAg}$-negative precore mutant $\mathrm{HBV}$ liver disease. HePATOLOGY 2002;36:219-226.

172. Papatheodoridis GV, Dimou E, Dimakopoulos K, Manolakopoulos S, Rapti I, Kitis G, et al. Outcome of hepatitis B e antigen-negative chronic hepatitis $\mathrm{B}$ on long-term nucleos $(\mathrm{t})$ ide analog therapy starting with lamivudine. Hepatology 2005;42:121-129.

173. Schiff ER, Dienstag JL, Karayalcin S, Grimm IS, Perrillo RP, Husa P, et al. Lamivudine and 24 weeks of lamivudine/interferon combination therapy for hepatitis B e antigen-positive chronic hepatitis B in interferon nonresponders. J Hepatol 2003;38:818-826.

174. Perrillo RP, Wright T, Rakela J, Levy G, Schiff E, Gish R, et al. A multicenter United States-Canadian trial to assess lamivudine monotherapy before and after liver transplantation for chronic hepatitis B. HePATOLOGY 2001;33:424-432.

175. Villeneuve JP, Condreay LD, Willems B, Pomier-Layrargues G, Fenyves $\mathrm{D}$, Bilodeau $\mathrm{M}$, et al. Lamivudine treatment for decompensated cirrhosis resulting from chronic hepatitis B. HEPATOLOGY 2000;31:207-210.

176. Yao FY, Bass NM. Lamivudine treatment in patients with severely decompensated cirrhosis due to replicating hepatitis B infection. [see comments]. J Hepatol 2000;33:301-307.

177. Fontana RJ, Hann HW, Perrillo RP, Vierling JM, Wright T, Rakela J, et al. Determinants of early mortality in patients with decompensated chronic hepatitis B treated with antiviral therapy. Gastroenterology 2002; 123:719-727.

178. Dienstag JL, Cianciara J, Karayalcin S, Kowdley KV, Willems B, Plisek S, et al. Durability of serologic response after lamivudine treatment of chronic hepatitis B. HePATOLOGY 2003;37:748-755.

179. Song BC, Suh DJ, Lee HC, Chung YH, Lee YS. Hepatitis B e antigen seroconversion after lamivudine therapy is not durable in patients with chronic hepatitis B in Korea. HePATOlogy 2000;32:803-806.

180. Lee KM, Cho SW, Kim SW, Kim HJ, Hahm KB, Kim JH. Effect of virological response on post-treatment durability of lamivudine-induced HBeAg seroconversion. J Viral Hepat 2002;9:208-212.

181. Ryu SH, Chung YH, Choi MH, Kim JA, Shin JW, Jang MK, et al. Long-term additional lamivudine therapy enhances durability of lamivudine-induced HBeAg loss: a prospective study. J Hepatol 2003;39:614619.

182. Lee HC, Suh DJ, Ryu SH, Kim H, Shin JW, Lim YS, et al. Quantitative polymerase chain reaction assay for serum hepatitis $\mathrm{B}$ virus DNA as a predictive factor for post-treatment relapse after lamivudine induced hepatitis B e antigen loss or seroconversion. Gut 2003;52:1779-1783.
183. Chien RN, Yeh CT, Tsai SL, Chu CM, Liaw YF. Determinants for sustained HBeAg response to lamivudine therapy. Hepatology 2003; 38:1267-1273.

184. van Nunen AB, Hansen BE, Suh DJ, Lohr HF, Chemello L, Fontaine H, et al. Durability of HBeAg seroconversion following antiviral therapy for chronic hepatitis B: relation to type of therapy and pretreatment serum hepatitis B virus DNA and alanine aminotransferase. Gut 2003;52:420-424.

185. Fung SK, Wong F, Hussain M, Lok AS. Sustained response after a 2-year course of lamivudine treatment of hepatitis $\mathrm{B}$ e antigen-negative chronic hepatitis B. J Viral Hepat 2004;11:432-438.

186. Allen MI, Deslauriers M, Andrews CW, Tipples GA, Walters KA, Tyrrell $\mathrm{DL}$, Brown N, et al. Identification and characterization of mutations in hepatitis B virus resistant to lamivudine. Lamivudine Clinical Investigation Group. Hepatology 1998;27:1670-1677.

187. Stuyver LJ, Locarnini SA, Lok A, Richman DD, Carman WF, Dienstag JL, Schinazi RF. Nomenclature for antiviral-resistant human hepatitis B virus mutations in the polymerase region. HePATOLOGY 2001;33:751-757.

188. Yuen MF, Sablon E, Hui CK, Yuan HJ, Decraemer H, Lai CL. Factors associated with hepatitis $\mathrm{B}$ virus DNA breakthrough in patients receiving prolonged lamivudine therapy. Hepatology 2001;34:785-791.

189. Melegari M, Scaglioni PP, Wands JR. Hepatitis B virus mutants associated with 3TC and famciclovir administration are replication defective. HePATOLOGy 1998;27:628-633.

190. Liaw YF, Chien RN, Yeh CT, Tsai SL, Chu CM. Acute exacerbation and hepatitis $\mathrm{B}$ virus clearance after emergence of YMDD motif mutation during lamivudine therapy. [see comments]. HePATOLOGY 1999;30:567-572.

191. Bartholomew MM, Jansen RW, Jeffers LJ, Reddy KR, Johnson LC, Bunzendahl $\mathrm{H}$, et al. Hepatitis-B-virus resistance to lamivudine given for recurrent infection after orthotopic liver transplantation. [see comments]. Lancet 1997;349:20-22.

192. Tipples GA, Ma MM, Fischer KP, Bain VG, Kneteman NM, Tyrrell DL. Mutation in HBV RNA-dependent DNA polymerase confers resistance to lamivudine in vivo. HePATOLOGY 1996;24:714-717.

193. Liaw YF, Chien RN, Yeh CT. No benefit to continue lamivudine therapy after emergence of YMDD mutations. Antivir Ther 2004;9:257-262.

194. Wong VW, Chan HL, Wong ML, Tam JS, Leung NW. Clinical course after stopping lamivudine in chronic hepatitis B patients with lamivudine-resistant mutants. Aliment Pharmacol Ther 2004;19:323-329.

195. Dienstag JL, Goldin RD, Heathcote EJ, Hann HW, Woessner M, Stephenson SL, et al. Histological outcome during long-term lamivudine therapy. Gastroenterology 2003;124:105-117.

196. Di Marco V, Marzano A, Lampertico P, Andreone P, Santantonio T, Almasio PL, et al. Clinical outcome of HBeAg-negative chronic hepatitis $\mathrm{B}$ in relation to virological response to lamivudine. HePATOLOGY 2004; 40:883-891.

197. Honkoop P, de Man RA, Niesters HG, Zondervan PE, Schalm SW. Acute exacerbation of chronic hepatitis $B$ virus infection after withdrawal of lamivudine therapy. Hepatology 2000;32:635-639.

198. Marcellin P, Chang TT, Lim SG, Tong MJ, Sievert W, Shiffman ML, et al. Adefovir dipivoxil for the treatment of hepatitis B e antigen-positive chronic hepatitis B. N Engl J Med 2003;348:808-816.

199. Hadziyannis SJ, Tassopoulos NC, Heathcote EJ, Chang TT, Kitis G, Rizzetto $\mathrm{M}$, et al. Adefovir dipivoxil for the treatment of hepatitis B e antigen-negative chronic hepatitis B. N Engl J Med 2003;348:800-807.

200. Hadziyannis SJ, Tassopoulos NC, Heathcote EJ, Chang TT, Kitis G, Rizzetto M, et al. Long-term therapy with adefovir dipivoxil for $\mathrm{HBeAg}$ negative chronic hepatitis B. N Engl J Med 2005;352:2673-2681.

201. Hadziyannis S, Tassopoulos N, Chang TT, Heathcote J, Kitis G, Rizzetto $\mathrm{M}$, et al. Long-term adefovir dipivoxil treatment induces regression of liver fibrosis in patients with $\mathrm{HBeAg}$-negative chronic hepatitis B: Results after 5 years of therapy [Abstract]. Hepatology 2005;42(Suppl):754A.

202. Schiff ER, Lai CL, Hadziyannis S, Neuhaus P, Terrault N, Colombo M, et al. Adefovir dipivoxil therapy for lamivudine-resistant hepatitis B in pre- and post-liver transplantation patients. HePATOLOGY 2003;38:14191427.

203. Schiff E, Lai CL, Neuhaus P, Tillmann HL, Samuel D, Villeneuve JP. Adefovir Dipivoxil (ADV) provides significant clinical benefit, reduces 
meld score and prevents transplantation in chronic hepatitis B patients wait-listed for liver transplantation (OLT) with Lamivudine-Resistance (LAM-R) [Abstract]. J Hepatol 2005;42(Suppl 2):5.

204. Snow A, Thibault V, Qi X, Zhu Y, Westland C, Arterburn S, et al. Combination of Adefovir Dipivoxil (ADV) and Lamivudine (LAM) prevented emergence of ADV resistance Mutations in chronic Hepatitis $B$ (CHB) patients with LAM-Resistant HBV [Abstract]. Gastroenterology 2005;128:M945.

205. Benhamou Y, Thibault V, Vig P, Calvez V, Marcelin AG, Fievet MH, et al. Safety and efficacy of adefovir dipivoxil in patients infected with lamivudine-resistant hepatitis B and HIV-1. J Hepatol 2006;44:62-67.

206. Chang TT, Gish R, Man R, Gadano A, Sollano J, Han KH, et al. Entecavir is superior to Lamivudine for the treatment of $\operatorname{HBEAg}(+)$ chronic hepatitis B: Results of Phase III study ETV - 022 in Nucleoside-Naive patients [Abstract]. HePATOLOGY 2004;40(Suppl):193A.

207. Westland CE, Yang H, Delaney WE, Gibbs CS, Miller MD, Wulfsohn $\mathrm{M}$, et al. Week 48 resistance surveillance in two phase 3 clinical studies of adefovir dipivoxil for chronic hepatitis B. HEPATOLOGY 2003;38:96-103

208. Angus P, Vaughan R, Xiong S, Yang H, Delaney W, Gibbs C, et al. Resistance to adefovir dipivoxil therapy associated with the selection of a novel mutation in the HBV polymerase. Gastroenterology 2003;125 292-297.

209. Villeneuve JP, Durantel D, Durantel S, Westland C, Xiong S, Brosgart $\mathrm{CL}$, et al. Selection of a hepatitis B virus strain resistant to adefovir in a liver transplantation patient. J Hepatol 2003;39:1085-1089.

210. Locarnini S, Qi X, Arterburn S, Snow A, Brosgart CL, Currie G, et al. Incidence and predictors of emergence of Adefovir resistant $\mathrm{HBV}$ during four years of Adefovir Dipivoxil (ADV) Therapy for patients with chronic hepatitis B (CHB) [Abstract]. J Hepatol 2005;42:17.

211. Lee YS, Suh DJ, Lim YS, Jung SW, Kim KM, Lee HC, et al. Increased risk of adefovir resistance in patients with lamivudine-resistant chronic hepatitis B after 48 weeks of adefovir dipivoxil monotherapy. HePATOLOGY 2006;43:1385-1391.

212. Fung SK, Andreone P, Han SH, Reddy KR, Regev A, Keeffe EB, et al. Adefovir-resistant hepatitis B can be associated with viral rebound and hepatic decompensation. J Hepatol 2005;43:937-943.

213. Durantel S, Werle B, Durantel D, Pichoud C, Currie G, Xiong S, et al. Different profiles of response to Adefovir Dipivoxil and factors that may influence response in patients with chronic Hepatitis B. HePATOLOGY 2004; $40: 654 \mathrm{~A}$

214. Westland C, Delaney Wt, Yang H, Chen SS, Marcellin P, Hadziyannis S, et al. Hepatitis B virus genotypes and virologic response in 694 patients in phase III studies of adefovir dipivoxil1. Gastroenterology 2003;125:107116.

215. Ono SK, Kato N, Shiratori Y, Kato J, Goto T, Schinazi RF, et al. The polymerase L528M mutation cooperates with nucleotide binding-site mutations, increasing hepatitis $\mathrm{B}$ virus replication and drug resistance. J Clin Invest 2001;107:449-455.

216. Chang TT, Gish RG, de Man R, Gadano A, Sollano J, Chao YC, et al. A comparison of entecavir and lamivudine for $\mathrm{HBeAg}$-positive chronic hepatitis B. N Engl J Med 2006;354:1001-1010.

217. Gish R, Chang TT, de Man R, Gadano A, Sollano J, Han KH, et al. Entecavir results in substantial virologic and biochemical improvement and $\mathrm{HBeAg}$ seroconversion through 96 weeks of treatment in $\mathrm{HBeAg}(+)$ Chronic hepatitis B patients (Study ETV-022) [Abstract]. HePaTOLOGY 2005;42(Suppl) :267A.

218. Lai CL, Shouval D, Lok AS, Chang TT, Cheinquer H, Goodman Z, et al. Entecavir versus lamivudine for patients with $\mathrm{HBeAg}$-negative chronic hepatitis B. N Engl J Med 2006;354:1011-1020.

219. Chang TT, Gish RG, Hadziyannis SJ, Cianciara J, Rizzetto M, Schiff ER, et al. A dose-ranging study of the efficacy and tolerability of entecavir in Lamivudine-refractory chronic hepatitis B patients. Gastroenterology 2005;129:1198-1209.

220. Sherman M, Yurdaydin C, Sollano J, Silva M, Liaw YF, Cianciara J, et al. Entecavir for treatment of lamivudine-refractory, $\mathrm{HBeAg}$-positive chronic hepatitis B. Gastroenterology 2006;130:2039-2049.
221. Colonno R, Rose R, Baldick C, Levine S, Pokornowski K, Yu C, et al. Resistance after two years of entecavir treatment in nucleoside-naive patients is rare. Hepatology 2006;45:1656-1665.

222. Tenney DJ, Levine SM, Rose RE, Walsh AW, Weinheimer SP, Discotto $\mathrm{L}$, et al. Clinical emergence of entecavir-resistant hepatitis $\mathrm{B}$ virus requires additional substitutions in virus already resistant to Lamivudine. Antimicrob Agents Chemother 2004;48:3498-3507.

223. Lok A, SchiffE, Tsai SL, Rustsgi VK, Schiffman M, Martin P, et al. Entecavir is effective irrespective of Baseline Alt nad HBV DNA Strata for Histological and Virological Endpoints [Abstract]. Gastroenterology 2005;128:742.

224. Entecavir Review Team. Briefing document for NDA 21-797, entecavir 0.5 and $1 \mathrm{mg}$ tablets and NDA 21-798, entcavir oral solution $0.05 \mathrm{mg} / \mathrm{mL}$. www.fda.gov/ohrms/dockets/ac/05/briefing/2005-4094B1_02_ FDA-Background-Memo.pdf.

225. Lai CL, Leung N, Teo EK, Tong M, Wong F, Hann HW, et al. A 1-year trial of telbivudine, lamivudine, and the combination in patients with hepatitis B e antigen-positive chronic hepatitis B. Gastroenterology 2005; 129:528-536.

226. Lai CL, Leung NW, Teo EK, Tong M, Wong F, Hann Hw Y, et al. Phase Iib extended-treatment trial of telbivudine (LdT) vs lamivudine vs combination treatment in hepatitis B patients: two year results [Abstract]. Gastroenterology 2005;128:A692.

227. Lai CL, Gane E, Liaw YF, Thongsawat S, Wang y, Chen Y, et al. Telbivudine (LDT) Vs. Lamivudine for Chronic Hepatitis B: First - year results from the international phase III globe trial [Abstract]. HEPATOLOGY 2005; 42 (Suppl):748A.

228. Lai CL, Gane E, Chao-Wei H, Thongsawat S, Wang Y, Chen Y, et al Two-Year results from the Globe Trial in patients with hepatitis B: Greater clinical and antiviral efficacy for telbivudine (LDT) vs. lamivudine [Abstract]. Hepatology 2006;44(Suppl):222A

229. Di Bisceglie AM, Lai CL, Gane E, Chen Y-C, Thongsawat S, Wang Y, et al. Telbivudine Globe Trial: Maximal early HBV suppression is predictive of optimal two-year efficacy in nucleoside-treated hepatitis $\mathrm{B}$ patients. HePATOLOGY 2006;44(Suppl):230A-231A.

230. Lim SG, Ng TM, Kung N, Krastev Z, Volfova M, Husa P, et al. A double-blind placebo-controlled study of emtricitabine in chronic hepatitis B. Arch Intern Med 2006;166:49-56.

231. Ristig MB, Crippin J, Aberg JA, Powderly WG, Lisker-Melman M, Kessels L, et al. Tenofovir disoproxil fumarate therapy for chronic hepatitis B in human immunodeficiency virus/hepatitis B virus-coinfected individuals for whom interferon-alpha and lamivudine therapy have failed. J Infect Dis 2002;186:1844-1847.

232. Peters MG, Anderson J, Lynch P, Tun L, Alston-Smith B, Carol L, et al Randomized controlled study of tenofovir and adefovir in chronic hepatitis B virus and HIV infection: ACTG A5127. Hepatology 2006;44: 1110-1116

233. Benhamou Y, Fleury H, Trimoulet P, Pellegrin I, Urbinelli R, Katlama C, et al. Anti-hepatitis B virus efficacy of tenofovir disoproxil fumarate in HIV-infected patients. Hepatology 2006;43:548-555.

234. Dore GJ, Cooper DA, Pozniak AL, DeJesus E, Zhong L, Miller MD, et al. Efficacy of tenofovir disoproxil fumarate in antiretroviral therapynaive and -experienced patients coinfected with HIV-1 and hepatitis B virus. J Infect Dis 2004;189:1185-1192.

235. Kuo A, Dienstag JL, Chung RT. Tenofovir disoproxil fumarate for the treatment of lamivudine-resistant hepatitis B. Clin Gastroenterol Hepatol 2004;2:266-272.

236. van Bommel F, Wunsche T, Mauss S, Reinke P, Bergk A, Schurmann D, et al. Comparison of adefovir and tenofovir in the treatment of lamivudine-resistant hepatitis B virus infection. Hepatology 2004;40:14211425 .

237. van Bommel F, Berg T. Reactivation of viral replication after replacement of tenofovir by adefovir. Hepatology 2005;42:239-240.

238. Verhelst D, Monge M, Meynard JL, Fouqueray B, Mougenot B, Girard PM, et al. Fanconi syndrome and renal failure induced by tenofovir: a first case report. Am J Kidney Dis 2002;40:1331-1333.

239. Yoo BC, Kim H, Lee KS, Kim TH, Paik SW, Ryu SH, et al. A 24-week clevudine monotherapy produced profound on-treatment viral suppres- 
sion as as sustained viral suppression and normalization of aminotransferase levels for 24 weeks off-treatment in $\operatorname{HBEAg}(+)$ chronic hepatitis B patients [Abstract]. HePATOLOGY 2005;42(Suppl):270A.

240. Yoo BC, Koh KC, Chung YH, Han BH, Byun KS, UM S, et al. Clevudine is highly efficacious in $\operatorname{HBEAg}(-)$ chronic Hepatits B patients with a sustained antiviral effect after cessation of therapy [Abstract]. HEPATOLOGY 2005; 42(Suppl):268A.

241. Andreone P, Cursaro C, Gramenzi A, Zavagliz C, Rezakovic I, Altomare $\mathrm{E}$, et al. A randomized controlled trial of thymosin-alphal versus interferon alfa treatment in patients with hepatitis B e antigen antibody-and hepatitis B virus DNA-positive chronic hepatitis B. HePATOLOGY 1996; 24:774-777.

242. Chien RN, Liaw YF, Chen TC, Yeh CT, Sheen IS. Efficacy of thymosin alpha1 in patients with chronic hepatitis B: a randomized, controlled trial. Hepatology 1998;27:1383-1387.

243. Mutchnick MG, Lindsay KL, Schiff ER, Cummings GD, Appelman HD, Peleman RR, et al. Thymosin alpha1 treatment of chronic hepatitis B: results of a phase III multicentre, randomized, double-blind and placebo-controlled study. J Viral Hepat 1999;6:397-403.

244. Zavaglia C, Severini R, Tinelli C, Franzone JS, Airoldi A, Tempini S, et al. A randomized, controlled study of thymosin-alphal therapy in patients with anti-HBe, HBV-DNA-positive chronic hepatitis B. Dig Dis Sci 2000;45:690-696.

245. Chan HL, Tang JL, Tam W, Sung JJ. The efficacy of thymosin in the treatment of chronic hepatitis B virus infection: a meta-analysis. Aliment Pharmacol Ther 2001;15:1899-1905.

246. Sung JJY LJ, Zeuzem S, Chow WC, Heathcote E, Perrillo R, Brosgart C, et al. A randomized double-blind phase II study of lamivudine compared to lamivudine plus adefovir dipivoxil for treatment naïve patients with chronic hepatitis B: week 52 analysis. J Hepatol 2003:25.

247. A Phase II Study of Lamivudine Compared to Lamivudine Plus Adefovir Dipivoxil for Subjects With Chronic Hepatitis B. http://ctr.gsk.co.uk/ Summary/lamivudine/II_NUC20912.

248. Peters MG, Hann H, Martin P, Heathcote EJ, Buggisch P, Rubin R, Bourliere $\mathrm{M}$, et al. Adefovir dipivoxil alone or in combination with lamivudine in patients with lamivudine-resistant chronic hepatitis B. Gastroenterology 2004;126:91-101.

249. Hung $\mathrm{CH}$, Lee CM, Lu SN, Wang JH, Tung HD, Chen $\mathrm{CH}$, et al. Combination therapy with interferon-alpha and ribavirin in patients with dual hepatitis B and hepatitis C virus infection. J Gastroenterol Hepatol 2005;20:727-732.

250. Liu CJ, Chen PJ, Lai MY, Kao JH, Jeng YM, Chen DS. Ribavirin and interferon is effective for hepatitis $\mathrm{C}$ virus clearance in hepatis $\mathrm{B}$ and $\mathrm{C}$ dually infected patients. Hepatology 2003;37:568-576.

251. Villa E, Grottola A, Buttafoco P, Colantoni A, Bagni A, Ferretti I, et al. High doses of alpha-interferon are required in chronic hepatitis due to coinfection with hepatitis $B$ virus and hepatitis $C$ virus: long term results of a prospective randomized trial. Am J Gastroenterol 2001;96:2973-2977.

252. Farci P, Mandas A, Coiana A, Lai ME, Desmet V, Van Eyken P, et al. Treatment of chronic hepatitis D with interferon alfa-2a. N Engl J Med 1994;330:88-94.

253. Farci P, Roskams T, Chessa L, Peddis G, Mazzoleni AP, Scioscia R, et al. Long-term benefit of interferon alpha therapy of chronic hepatitis $\mathrm{D}$ : regression of advanced hepatic fibrosis. Gastroenterology 2004;126: 1740-1749.

254. Niro G, Ciancio A, Gaeta GB, Smedile A, Marrone A, Olivero A, et al. Pegylated interferon alpha- $2 \mathrm{~b}$ as monotherapy or in combination with ribavirin in chronic hepatitis delta. HePATOLOGY 2006;44:713-720.

255. Castelnau C, Le Gal F, Ripault MP, Gordien E, Martinot-Peignoux M, Boyer $\mathrm{N}$, et al. Efficacy of peginterferon alpha-2b in chronic hepatitis delta: relevance of quantitative RT-PCR for follow-up. HEPATOLOGY 2006; 44:728-735.

256. Lau DT, Doo E, Park Y, Kleiner DE, Schmid P, Kuhns MC, et al. Lamivudine for chronic delta hepatitis. HePaTOlogy 1999;30:546-549.

257. Di Martino V, Thevenot T, Colin JF, Boyer N, Martinot M, Degos F, et al. Influence of HIV infection on the response to interferon therapy and the long-term outcome of chronic hepatitis B. Gastroenterology 2002; 123:1812-1822.

258. Hoff J, Bani-Sadr F, Gassin M, Raffi F. Evaluation of chronic hepatitis B virus (HBV) infection in coinfected patients receiving lamivudine as a componet of anti-human immunodeficiency virus regimens. Clin Infect Dis 2001;32:963-969.

259. Benhamou Y, Bochet M, Thibault V, Di Martino V, Caumes E, Bricaire $\mathrm{F}$, et al. Long-term incidence of hepatitis $\mathrm{B}$ virus resistance to lamivudine in human immunodeficiency virus-infected patitents. HEPATOLOGY 2000;31:1030-1031

260. Bani-Sadr F, Palmer P, Scieux C, Molina JM. Ninety-six-week efficacy of combination therapy with lamivudine and tenofovir in patients coinfected with HIV-1 and wild-type hepatitis B virus. Clin Infect Dis 2004; 39:1062-1064.

261. Sheldon JA, Corral A, Rodes B, Mauss S, Rockstroh J, Berger F, et al. Risk of selecting K65R in antiretroviral-naive HIV-infected individuals with chronic hepatitis B treated with adefovir. AIDS 2005;19:2036-2038.

262. Lok AS, Liang RH, Chiu EK, Wong KL, Chan TK, Todd D. Reactivation of hepatitis $\mathrm{B}$ virus replication in patients receiving cytotoxic therapy. Report of a prospective study. Gastroenterology 1991;100:182-188.

263. Yeo W, Chan PK, Zhong S, Ho WM, Steinberg JL, Tam JS, et al. Frequency of hepatitis $\mathrm{B}$ virus reactivation in cancer patients undergoing cytotoxic chemotherapy: a prospective study of 626 patients with identification of risk factors. Journal of Medical Virology 2000;62:299-307.

264. Yeo W, Johnson PJ. Diagnosis, prevention and management of hepatitis B virus reactivation during anticancer therapy. HePATOLOGY 2006;43: 209-220.

265. Cheng AL, Hsiung CA, Su IJ, Chen PJ, Chang MC, Tsao CJ, et al. Steroid-free chemotherapy decreases risk of hepatitis B virus (HBV) reactivation in HBV-carriers with lymphoma. Hepatology 2003;37: 1320-1328

266. Ostuni P, Botsios C, Punzi L, Sfriso P, Todesco S. Hepatitis B reactivation in a chronic hepatitis B surface antigen carrier with rheumatoid arthritis treated with infliximab and low dose methotrexate. Ann Rheum Dis 2003;62:686-687.

267. Esteve M, Saro C, Gonzalez-Huix F, Suarez F, Forne M, Viver JM. Chronic hepatitis B reactivation following infliximab therapy in Crohn's disease patients: need for primary prophylaxis. Gut 2004;53:1363-1365.

268. Lau GK, He ML, Fong DY, Bartholomeusz A, Au WY, Lie AK, et al. Preemptive use of lamivudine reduces hepatitis B exacerbation after allogeneic hematopoietic cell transplantation. HePATOLOGY 2002;36:702-709.

269. Lau GK, Yiu HH, Fong DY, Cheng HC, Au WY, Lai LS, et al. Early is superior to deferred preemptive lamivudine therapy for hepatitis B patients undergoing chemotherapy. Gastroenterology 2003;125:17421749.

270. Rossi G, Pelizzari A, Motta M, Puoti M. Primary prophylaxis with lamivudine of hepatitis B virus reactivation in chronic HbsAg carriers with lymphoid malignancies treated with chemotherapy. Br J Haematol 2001; 115:58-62.

271. Chan TM, Fang GX, Tang CS, Cheng IK, Lai KN, Ho SK. Preemptive lamivudine therapy based on HBV DNA level in HBsAg-positive kidney allograft recipients. HEPATOLOGY 2002;36:1246-1252.

272. Hui CK, Cheung WW, Au WY, Lie AK, Zhang HY, Yueng YH, et al. Hepatitis B reactivation after withdrawal of pre-emptive lamivudine in patients with haematological malignancy on completion of cytotoxic chemotherapy. Gut 2005;54:1597-1603.

273. Kondili LA, Osman H, Mutimer D. The use of lamivudine for patients with acute hepatitis B (a series of cases). J Viral Hepat 2004;11:427-431.

274. Tillmann HL, Haden J, Leifeld L, Zachou K, Canbay A, Eisenbach C, et al. Safety and efficacy of lamivudine in patients with severe acute or fulminant hepatits B: A multicenter experience. J Viral Hepatol 2006;4: 256-263.

275. Tassopoulos NC, Koutelou MG, Polychronaki H, Paraloglou-Ioannides M, Hadziyannis SJ. Recombinant interferon-alpha therapy for acute hepatitis B: a randomized double-blind, placebo-controlled trial. J Viral Hepat 1997;4:387-394. 